\title{
THE MESENCEPHALIC ROOT OF THE FIFTH NERVE A COMPARATIVE ANATOMICAL STUDY
}

\author{
ERNST WEINBERG
}

Tartu (Dorpat), Esthonia, and Department of Anatomy, University of Michigan

THIRTY-FIVE FIGURES

\section{CONTENTS}

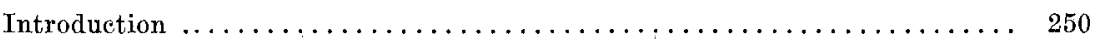

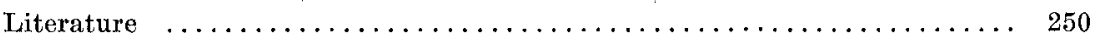

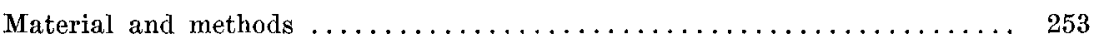

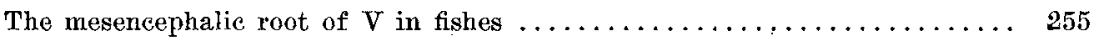

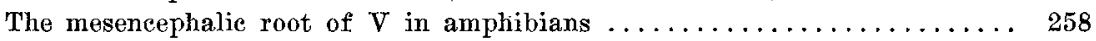

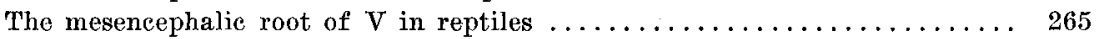

The mesencephalic root of $\mathrm{V}$ in the turtle $\ldots \ldots \ldots \ldots \ldots \ldots \ldots \ldots 266$

The mesencephalie root of $\mathrm{V}$ in the alligator $\ldots \ldots \ldots \ldots \ldots \ldots \ldots 273$

The mesencephalic root of $\mathrm{V}$ in birds ...................... 280

The mesencephalic root of $\mathrm{V}$ in the chicken $\ldots \ldots \ldots \ldots \ldots \ldots \ldots \ldots . \ldots \ldots 1$

The mesencephalic root of $\mathrm{V}$ in the duck $\ldots \ldots \ldots \ldots \ldots \ldots \ldots \ldots . \ldots \ldots 4$

The mesencephalie root of $\mathrm{V}$ in the dove $\ldots \ldots \ldots \ldots \ldots \ldots \ldots \ldots 290$

The mesencephalic root of $V$ in the English sparrow ........... 299

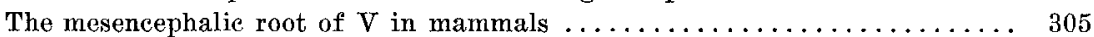

The mesencephalic root of $\mathrm{V}$ in the rabbit $\ldots \ldots \ldots \ldots \ldots \ldots \ldots, 306$

The mesencephalie root of $\mathrm{V}$ in the mouse $\ldots \ldots \ldots \ldots \ldots \ldots \ldots, 317$

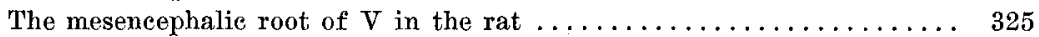

The mesencephalic root of $\mathrm{V}$ in the cat $\ldots \ldots \ldots \ldots \ldots \ldots \ldots \ldots \ldots \ldots \ldots$

The mesencephalie root of $\mathrm{V}$ in the monkey $\ldots \ldots \ldots \ldots \ldots \ldots \ldots, 343$

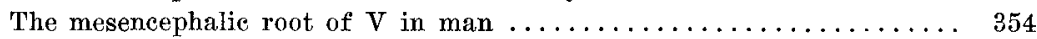

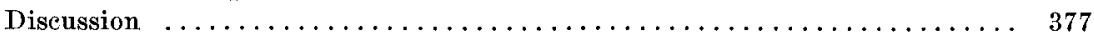

I. Position and arrangement of cells of the mesencephalic root of V. 377

II. Character of cells ......................... 382

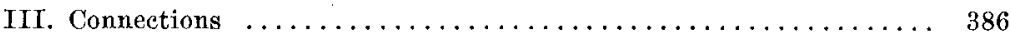

IV. Relation to the nucleus loci coerulei ................ 388

V. Relation to the trochlear root $\ldots \ldots \ldots \ldots \ldots \ldots \ldots \ldots \ldots \ldots, 389$

VI. Question of possible decussation of the mesencephalic root of V. . 389

VII. Emergence of the mesencephalic root of $\mathrm{V}$ from the brain .... 390

VIII. Ascending and descending fibers in the mesencephalic root of V., 390

IX. Peripheral distribution $\ldots \ldots \ldots, \ldots \ldots \ldots \ldots \ldots \ldots \ldots \ldots, 391$ 


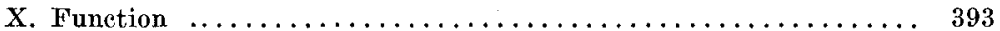

XI. Relation to the eye museles $\ldots \ldots \ldots \ldots \ldots \ldots \ldots \ldots \ldots \ldots \ldots, 396$

XII. General conception $\ldots \ldots \ldots \ldots \ldots \ldots \ldots \ldots \ldots \ldots \ldots \ldots \ldots . \ldots \ldots$

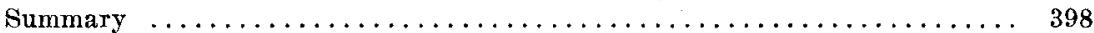

Bibliography $\ldots \ldots \ldots \ldots \ldots \ldots \ldots \ldots \ldots \ldots \ldots \ldots \ldots \ldots \ldots \ldots \ldots \ldots \ldots \ldots$

\section{INTRODUCTION}

The mesencephalic root of the fifth nerve has been considered in a number of contributions dealing with the structure of the brain stem. Several experimental studies have been made to throw light on the morphologic and functional character of this root. However, comparative studies concerned in a detailed description of the mesencephalic root of $\mathrm{V}$ in different forms are but few. It is for this reason that at the suggestion of Prof. G. Carl Huber the present study was undertaken. He placed at my disposal the rich series of neurological preparations of the Anatomical Laboratory, on the basis of which this study was made. I am glad to take this opportunity of thanking him for this and for the time and interest he has shown in this work. My thanks are also extended to Dr. Elizabeth C. Crosby for her unfailing help and suggestions throughout the whole progress of this study.

\section{LITERATURE}

In 1846 Stilling, in describing the intracerebral course of the trochlear nerve, distinguished in this nerve three parts. One of these parts, the 'pars inferior curriculi nervi trochlearis,' can be recognized as the mesencephalic root of $V$. He derived also from the same nucleus a root of the trigeminal nerve. The interest of Deiters ('65) was aroused by the special appearance of the cells lying around the aqueduct near the origin of the trochlear nerve and accompanying this nerve, in a regular row, in its course in the brain. He found the cells similar to those of the gasserian ganglion and doubted their being the direct origin of the trochlear nerve. In the mole, rabbit, and the dog, Stieda ('70) described the cells of the trochlear nucleus as having 
large size and round or elliptical form, and possessing one or two processes, which cells differed in their form from other elements of the central nervous system. According to this author, this nucleus extended in the rabbit from the corpora quadrigemina anteriora to the region of the tri. geminal root. In the frontal part of the nucleus the number of cells was not great, only two or three in each cross-section. They appeared in cross-sections as a vertical band formed by one or two cell lines. The caudal portion of the nucleus lay by the side of the IVth ventricle. From this 'trochlear nucleus' Stieda derived also the frontal fibers of the 'small root' of the trigeminal nerve. It is evident that the cells observed by Deiters near the origin of the trochlear nerve and described by Stieda as the cells of the trochlear nucleus are the neurones of the mesencephalic root of $V$. The caudalward-running fiber bundles of the trochlear nerve in the description of Henle ('71) can also be identified as the mesencephalic root of V. Later ('79), Henle described this root as the 'anterior or superior' root of trigeminus, which enters the portio minor of this nerve.

The first clear differentiation of the mesencephalic root of $V$ from the trochlear nerve was given by Meynert ('67, '72). This author pointed out that the semilunar-shaped bundle at the inner side of the cerebellar peduncle is a root of the Vth nerve, and not a component of the IVth, this latter having only one root-that designated by Stilling as the anterior root. Meynert recognized the large cells in the gray substance of the IVth ventricle and extending upward to the level of the corpora quadrigemina anteriora; as the origin of this 'superior or descending root' of $\mathrm{V}$.

The fibers composing this root "originate at the outermost border of the gray matter that surrounds the aqueduct of Sylvius, in small collections of large bladder-shaped eells $60 \mu$ in length and $45-60 \mu$ in breadth, and form themselves by degrees into a series of bundles whose transversely-cut surfaces, succeeding each other like the links of a chain (as seen in cross sections made in this region), lie in a curved line around the outer edge of the thick wall of gray substance, which surrounds the aqueduct." 
The point of view of Meynert was accepted in its main features by Forel ('77), Duval ('78, '79), Huguenin ('79), and by all later observers, except Golgi ('93), who still considered it as a part of the IVth nerve. Forel ('77), Duval ('79), and S. Ganser ('82) have identified the mesencephalic root of $\mathrm{V}$ in the mole where it is more readily studied by reason of the practical absence of the trochlear nerve.

Mayer ('81), Burckhardt ('92), van Gehuchten ('95), Goronowitsch ('88), Houser ('01), Tello ('09) described the mesencephalic root of $\mathrm{V}$ in fishes; Osborn ('88) gave an account of it in amphibians, Rabl-Rückhard ('94) in snakes, Turner ('91), Ponjatowsky ('92), and Brandis ('95) in birds. Frankl-Hochwart ('02) has identified the mesencephalic root of $\mathrm{V}$ in Sphalax typhlus, and Hatscheck and Schlesinger ('02) in Delphinus delphis.

Comparative studies of the mesencephalic root of $V$ in mammals have been made by Valeton ('08) and Hulles ('07). Johnston ('05, '09) and van Valkenburg ('11) have described the mesencephalic root of $\mathrm{V}$ in all classes of vertebrates.

The character of the cells of origin of the mesencephalic root of $\mathrm{V}$ in mammals has been considered by Lugaro ('94, '95), Ramón y Cajal ('96), Kure ('99), Bickel ('02), and several other authors. P. Ramón y Cajal ('04) has studied the cells in amphibians, reptiles, and birds.

All these studies have shown that the mesencephalic root of $\mathrm{V}$ is a constant formation in the series of vertebrates from selachians upward. However, many controversies have existed as to its significance which have not as yet been fully decided by either physiological experimentation nor by clinical observation. Therefore, the conceptions of the functional character of mesencephalic root of $V$ are based chiefly on morphological data and on the conceptions of its central and peripheral connections. The knowledge of these connections has been furnished partly by the purely anatomical studies of fiber preparations done by several of the above-quoted authors, especially by Ramón y Cajal. Important contributions to this knowledge are provided by a number of experi- 
mental observations carried on by means of either the Marchi method or the chromatolytic method. The experimental works in which data regarding the mesencephalic root of $\mathrm{V}$ can be found are those of Bregmann ('92), Gudden ('92), Kljatschkin ('97), Probst ('99), Wallenberg ('04), van Londen ('07), Mahaim ('08), Kohnstamm and Quensel ('08), Economo and Karplus ('09). Special experimental observations on the mesencephalic root of $\mathrm{V}$ are those of May and Horsley ('10), Willems ('11), Kosaka ('12), Allen ('19), and Thelander ('24). ${ }^{1}$

References to many of the above-quoted works and to several others will be made during the description of the mesencephalic root of $\mathrm{V}$ in different animals and in the discussion. The findings of the authors will be then considered and compared with those of our own. Therefore, in order to avoid frequent reiterations, an extensive preliminary discussion of the literature is omitted.

\section{MATERIAL AND METHODS}

The material employed in the present studies consists of complete series of brain stems of different animals. For the most part more than one series has been available for the study of the mesencephalic root of $\mathrm{V}$ in the respective animal. Cell as well as fiber preparations have been used. The outlines of each section of toluidin-blue material were drawn under the projection apparatus of Edinger at a magnification of 40 diameters. Each individual cell was then identified under the microscope and its position checked. Thus a fairly exact conception of the position of each cell and of the arrangement of the cells has been obtained. In order to obtain an exact knowledge of the distribution of the cells of mesen.

\footnotetext{
${ }^{1}$ The terms applied by different authors to the mesencephalie root of $\mathrm{V}$ have been numerous: "superior or descending root of V" (Meynert, '72), 'trophische Wurzel des Trigeminus' (Merkel, '74), 'absteigende Wurzel des Trigeminus' (Schwalbe, '81), 'cerebrale Trigeminuswurzel' (Obersteiner, '81), 'noyau accessoire ou descendant' (Ramón y Cajal, '09). To the nucleus of the mesencephalic root of $\mathrm{V}$ of submammals often the term 'nucleus magnocellularis tecti,' 'Dachkern' or roof-nucleus (Rohon, '78), has been applied.
} 
cephalic root of $\mathrm{V}$ in the brain stem of different forms, the cells in each section have been counted and placed in a table. Some errors may have entered into the calculations through counting a cell twice in two succeeding sections. The size of cells has been measured by drawing their outlines under a camera lucida with Leitz objective 6 , ocular 4 . The measurements obtained from the outlines thus drawn were divided by the corresponding magnification, which at the cameralucida projection was 730 diameters. For the cell measurements only toluidin-blue material was used.

The graphic reconstructions were made by projecting the outlines of each cross-section into a horizontal plane at the same magnification $(X 40)$ as the original outlines of the sections.

The outlines of the final drawings were made under the projection apparatus and the results controlled by microscopic study. The cells were drawn by the use of a camera lucida.

The measurements given in the descriptions for the relationships of the mesencephalic root of $V$ to other structures are made chiefly by taking into consideration the thickness of the preparations and the number of the serial sections which lie between the sections where the limits of the corresponding structures are seen. Errors may have been introduced in these measurements through possible tiltings of the section.

List of the material studied

Brook trout (Salvelinus fontinalis, Mitehill)

Bowfin (Amia calva)

Frog (Rana temporaria)

Turtle (Chrysemys marginata)

Alligator (Alligator mississippiensis)
Toluidin-blue preparations

1 series (cross $40 \mu$ )

1 series (eross $40 \mu$ )

2 series (horizontal $20 \mu$ ) 2 series (sagittal $20 \mu$ and $15 \mu$ )

3 series (sagittal $50 \mu, \quad 1$ series (sagittal 15 $\mu$ ) horizontal $20 \mu$, cross $20 \mu$ )

3 series (sagittal $20 \mu, \quad 4$ series (1 cross, 1 horizontal $20 \mu, \quad$ sagittal-Weigert, cross $20 \mu$ ) 
Chicken (Gallus domesticus)

Duck (Anas domestica)

Dove (Columba domestica) of one day

Dove of eight days

Dove of ten days

Dove adult

English sparrow

(Passer domesticus)

Rabbit (Lepus cuniculus), embryo of $3 \mathrm{em}$.

Rabbit one week before birth

Rabbit one day after birth

Rabbit six days after birth

Mouse (Mus musculus), embryo near term

Mouse adult

Rat (Mus norvegicus albinus) three days after birth

Rat adult

Cat (Felis domestica)

Monkey (Macacus rhesus)

Man (Homo)
Toluidin-blue preparations

1 series (sagittal $40 \mu$ )

1 series (cross $40 \mu$ )

1 series (cross $15 \mu$ )

1 series (cross $20 \mu$ )

1 series ( $\operatorname{cross} 20 \mu)$

2 series (cross $40 \mu$, horizontal $50 \mu$ ) 2 series (cross, sagittal)

4 series (cross, sagittal, 4 series ( 1 horizontal, 2 horizontal $40 \mu$ ) 3 cross)

3 series (cross, sagittal, horizontal)

2 series (sagittal $10 \mu$ )

2 series (sagittal $12 \mu$

and $15 \mu$ )

2 series (sagittal $10 \mu$ and $20 \mu$ )

1 series (sagittal $20 \mu$ )

2 series (sagittal, horizontal $15 \mu$ )

1 series (sagittal $15 \mu$ )

2 series (sagittal $20 \mu$ )

2 series (cross $20 \mu$ )

1 series (cross $50 \mu$ )

1 series (cross $50 \mu)$

1 series (eross $50 \mu$ )
2 series (sagittal, cross)

1 series (eross $50 \mu$ )

The toluidin-blue preparations were in the main fixed in the alcohol-mercuric chloride-trichloracetic mixture (Huber, '27), embedded in paraffin, cut in series by the 'water on the knife' method, and stained in toluidin-blue (Grübler). The chrom-silver series was prepared after a pyridin-silver method, embedded in paraffin, and cut serially by the 'water on the knife' method.

\section{THE MESENCEPHALIC ROOT OF $\mathrm{V}$ IN FISHES}

The nucleus of the mesencephalic root of $V$ was recognized in teleosts by Mayser ('81) and in Acipenser by Goronowitsch ('88). A description of the root and its cells of origin in Trutta fario, as seen in Golgi preparations, was given by 
van Gehuchten ('95). Tello ('09) described the cells in young trout. Later important studies on the mesencephalic root of $\mathrm{V}$ in fishes were those of Johnston ('05, '09) and of van Valkenburg ('11). Johnston described the root in Scyllium canicula, Scyllium stellare, Acipenser, and Squalus. Van Valkenburg studied the root in Scyllium canicula, Acanthias vulgaris, Mustelus vulgaris, Raja clavata, Gadus morrhua, Tinca tinca, and Lophius piscatorius. The studies of these authors show that the cells of the mesencephalic root of $\mathrm{V}$ are present in selachians and in teleosts. They have not been identified in cyclostomes (Petromyzon planeri, van Valkenburg). In selachians the cells of the mesencephalic root of $V$ lie dorsal to the aqueduct and to the optic ventricle. They extend from the region of the posterior commissure to the anterior medullary velum (Johnston, '09; Kappers, '20). In teleosts the cells are located in the frontal region of the midbrain and lie ventral to the ventricular cavity of the optic lobes, though still dorsal to the aqueduct (van Valkenburg). We found in toluidin preparations of the trout forty-four cells on either side in the region of the posterior commissure. They have a frontocaudal extension of about $0.6 \mathrm{~mm}$. and are situated frontal to the level of the oculomotor nucleus. The cells of the mesencephalic root of $V$ are not observed in the trout in the median plane just above the aqueduct, but in the medial portion of the ventral wall of the optic ventricle. Often they lie in the ependymal layer, sometimes among the fibers of the posterior commissure, occasionally ventral to these fibers and lateral to the aqueduct.

In Amia calva, as in the trout, the cells of the mesencephalic root of $V$ are situated in the region of the posterior commissure. Unlike trout, in Amia the cells are observed in a medial position in the roof of the aqueduct as well as in the medial part of the ventral wall of the optic ventricles (fig. 1). The cells of the mesencephalic root of $\mathrm{V}$ disappear in Amia at the level of the caudal limit of the posterior commissure; they extend rostral to this level for a distance of about $0.5 \mathrm{~mm}$. In toluidin preparations of Amia there were 
counted fifty-two cells in the roof of the aqueduct and thirteen cells on either side in the optic lobes. ${ }^{2}$ The medial cells lie among the fibers of the posterior commissure, often among the ependymal cells. The lateral cells are situated chiefly in the ependymal layer, sometimes bulging out into the ventricular cavity, as has been described by Johnston for other fishes. ${ }^{3}$ In a few cross-sections the medial cells are arranged in a row close to the ependymal cells, dorsal to the posterior commissure.

In Amia, as in the trout, some of the cells of the mesencephalic root of $\mathrm{V}$ seem to be provided with only one process.

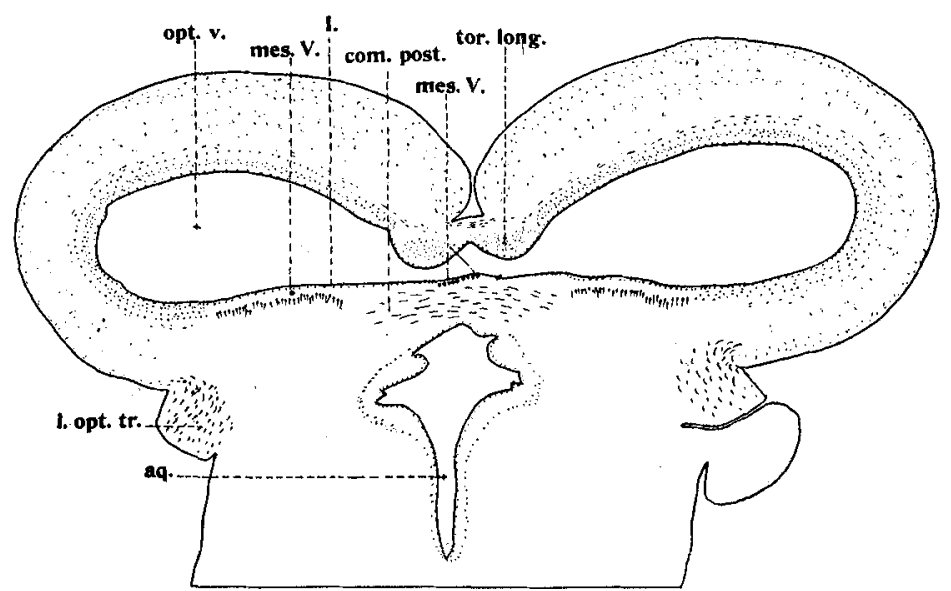

Fig. 1 Cross-section through the midbrain of Amia calva in the region of the posterior commissure. Toluidin-blue preparation. $\times 11$. aq., aqueduct; com.post., commissura posterior; l.opt.tr., lateral optic tract; mes.V., cells of the mesencephalic root of $\mathrm{V}$; opt.v., optic ventricle; tor.long., torus longitudinalis; I., ependymal layer of the tectum.

"For representatives of each form studied there has been made a careful cell count of the cells in the nucleus of the mesencephalic root of $\mathrm{V}$, allocated as to lateral, intermediate, and medial cell groups and arranged in tabular form, giving the cell count per section. These tables are on file in the Anatomical Laboratory of the University of Michigan. They seem too extensive for publication in full. In summarized form the data collected appear in tables 1 , 2 , and 3 .

${ }^{3}$ Sargent ('01, '04) and Houser ('01) have even thought that the processes of the cells of the mesencephalie root of $V$ constitute a part of the Reissner's fiber. 
However, often cells with two or more processes are observed in both fishes. Sometimes these processes appear deeply stained in toluidin-blue preparations. Sometimes in addition to one or two thick, deeply stained processes there are observed several very thin and short, faintly stained processes.

The course of the mesencephalic root of $V$ in fishes has been described by van Gehuchten, Johnston, and van Valkenburg. Its emergence from the brain has not as yet been made entirely clear. Johnston is of the opinion that the root joins the sensory root of V. Van Valkenburg describes it in Scyllium as joining the motor root of $V$, while in Lophius the mesencephalic root of $V$ as well as the motor fibers of $V$ intermingle with the sensory fibers of $\mathrm{V}$.

\section{THE MESENCEPHALIO ROOT OF $\mathrm{V}$ IN AMPHIBIANS}

In the frog (Rana temporaria) the cells of the nucleus of the mesencephalic root of $V$ are located in the frontal portion of the tectum opticum, in which region they occupy a relatively lateral position. The most medial cells lie at a distance of about $0.3 \mathrm{~mm}$. from the midline. The main accumulations of the cells of the mesencephalic root of $V$ are seen in the dorsofrontal and mediofrontal sectors of the wall of the optic ventricle (fig. 2), a few of the cells are found in the lateral portion of the wall and certain cells lie even ventral to the optic ventricle. No cells of the nucleus of the mesencephalic root of $V$ are to be observed caudal to the tectum nor in its dorsocaudal wall. The more ventral cells lie ventral to the fibers of the tectal commissure and lateral to the aqueduct. The nucleus of the mesencephalic root of $\mathrm{V}$ begins dorsally about $0.3 \mathrm{~mm}$. below the upper surface of the optic tectum, and extends, in dorsoventral direction, to a distance of about $1.2 \mathrm{~mm}$. The ventral border of the posterior commissure lies about $1.1 \mathrm{~mm}$. below the upper surface of the optic tectum. Thus some of the cells of the nucleus of the mesencephalic root of $\mathrm{V}$ are situated ventral to this commissure and extend along the side of the aqueduct for a dis- 
tance of about $0.4 \mathrm{~mm}$. in dorsoventral direction. The cells of the mesencephalic root of $V$ are generally not found in the caudal half of the optic tectum. Indeed, the main cell masses are confined to the frontal third of it.

In the frog, Larsell ('23) has seen a few cells of the mesencephalic root of $\mathrm{V}$ in the region of the velum. These are considered by him as aberrant in position, but "suggestive in accounting for the fibers of the caudal root of the IV nerve."

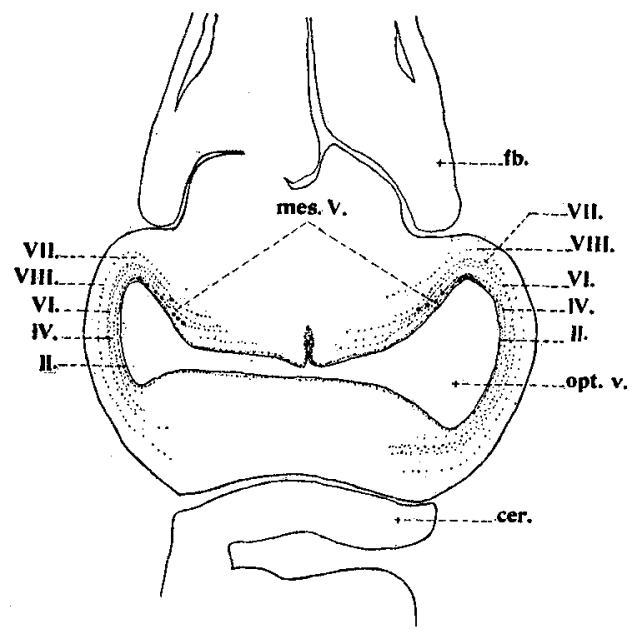

Fig. 2 Horizontal section through the midbrain of frog. The section is farther ventral on the left side of the figure than on the right. Toluidin-blue preparation. $\times 10$. cer., cerebellum; $f b$., forebrain; mes.V., cells of the mesencephalic root of $\mathrm{V}$; opt.v., optic ventriele; II., IV., VI., VII., VIII., layers of the tectum.

In the frog the position of the nucleus of the mesencephalic root of $\mathrm{V}$ differs somewhat from that described for Necturus by Johnston ('09) and by C. Judson Herrick ('17). In Necturus, according to these authors, the cells are located throughout the length of the tectum, although near the anterior border they are very few in number. Similar relations have been described for Cryptobranchus by Johnston and by Röthig ('27). In the toad, Johnston found the cells of this 
nucleus in the anterior part of the tectum, a position corresponding to that above described for frog. In the toad, beside two large groups of cells in the anterior wall of the tectum, Johnston ('09) also found a large collection of cells extending across the median line, continuous with the two lateral groups. These median cells are lacking in the frog.

In the frog the more lateral cells are, in general, situated nearer to the ventricular cavity of the tectum than are the more medial and ventral ones. . The lateral cells are mostly found in the second layer of Cajal, ${ }^{4}$ often very close to the ependymal layer-while the more medial cells lie sometimes in the third or fourth layers and, when ventral to the level of the optic ventricle, even in the sixth layer.

The cells of the nucleus of the mesencephalic root of $\mathrm{V}$ are quite scattered in frog; in each horizontal section the number varies from one to eleven. Without being clustered into welldefined nuclear groups, the cells of the nucleus of mesencephalic root of $V$ nevertheless reveal in the frog certain differences in appearance according to their relative position within the optic tectum. As a matter of convenience in description and for comparison with other forms we have distinguished three groups of cells: a dorsolateral, an intermediate, and a ventromedial. Such subdivisions are based on differences observed in the appearance of the cells, which differences are probably due, to some extent, to differences in orientation with reference to the plane of section. In horizontal sections the most lateral cells present, in general, an irregular, polygonal form. Being located at the frontal pole of the optic ventricle, they partly surround this pole on its dorsal side. They are found mostly in the mediofrontal wall of the optic ventricle, some are present also in its laterofrontal wall. The cells in the latter region do not extend as

\footnotetext{
1 The various layers of the tectum of amphibians and reptiles are indicated according to the nomenclature employed by $P$. Ramón $y$ Cajal ('96) in the deseription of the superior collieular region of chameleon, which nomenclature has been adopted by Huber and Crosby ('26). According to this nomenclature, the ependymal layer is indicated as the first layer, the layer bordering the ependyma immediately on the outside as the second layer, etc.
} 
far caudalward as in the former. The majority of the cells of this dorsolateral group lie in the second or third layer of Cajal. Farther medialward, in the medial wall of the optic ventricle, the cells are frequently found farther removed from the ventricular cavity, usually being observed in the third and fourth layers of Cajal. The shape of these intermediate cells is for the most part oval, the long axis of the cells being oriented parallel to the optic ventricle and lying obliquely across the field (in horizontal sections) with the caudal pole directed medialward and the frontal pole lateralward. In a more ventral position than these intermediate cells, cells are found which differ in shape from the others by being in general more regularly round. These ventromedial cells are situated ventral to the ventricular cavity of the tectum and to the fibers of the posterior commissure. They are still farther removed from the ventricular cavity than are the intermediate cells and lie by the side of the aqueduct in the frontoventral wall of the optic ventricle.

The dorsolateral and intermediate cells are practically equal in number. The number of the ventromedial cells is much less than that of either of the two other groups as determined in careful serial-cell counts. In toluidin-blue preparations the cells of the mesencephalic root of $\mathrm{V}$ present a somewhat more violet color than do the other nerve cells. Around the nucleus there is found a paler zone. On the cells of the dorsolateral group there can be seen relatively short, stained processes and sometimes a less deeply stained process directed toward the periphery of the tectum. In the cells of the intermediate group there is sometimes visible a pale process arising from the region of the axon hillock and directed lateralward. Occasionally a lightly stained and outwardly directed process can be found in these cells. On the cells of the ventromedial group no processes can be distinguished in toluidin-blue preparations. The average size of the cells of the dorsolateral group is $18 \mu$, that of the intermediate group about $19 \mu$, and that of the ventromedial group, $21 \mu$. The cells of the ventromedial group are thus 
the largest. The cells of the ventromedial and dorsolateral groups are also less elongated than the cells of the intermediate group. This latter point is indicated by the difference in the average shorter and longer diameters of these cells, which is much greater in the cells of the intermediate group $(13.4 \mu$ ) than in the two other groups (about $5 \mu$ to $6 \mu$; tables 2 and 3 ). In chrom-silver preparations the cells of the mesencephalic root of $\mathrm{V}$ in frog are well impregnated, very generally better so than other cells. This is in accordance with the statements of P. Ramón y Cajal ('04). Thus the cells of the mesencephalic root of $V$ are clearly distinguished from other tectal elements through their greater size and better impregnation. The neurofibrillar network is often clearly distinguishable in our material. In many cells a long and quite straight process is observed (fig. 35, $a^{1}$.). This process is directed toward the periphery of the tectum and in sagittal sections can often be seen to enter the deep medullary layer (seventh layer of Cajal). Its course toward this layer is a quite direct one, but at the inner border of the layer it is occasionally seen to bend into a plane parallel to the optic ventricle. The cell itself lies, as has been described previously, in the deeper layers of the tectum, mainly in the second. A cell has been seen, the process of which ramifies at a certain distance from the cell body into two branches (fig. 35, a.). One branch is directed toward the periphery of the tectum and is traceable into the fifth layer while the other assumes apparently a different course. It is cut off at a shorter distance from the point of ramification than the former (fig. 35, a.). In many cells one to three short processes are observed. The short processes end usually in the fourth layer. Sometimes they are not traceable out of the second layer. The short processes are sometimes quite thick, thicker than the long ones. Some of the short processes are, however, thinner than the latter. In some cases the short process is seen to embrace in basket-like fashion a cell of the fourth layer. A cell of mesencephalic root of $\mathrm{V}$ has been observed which, lying in the fourth layer, embraces a small 
cell of this layer with the slightly elongated pole of its own cell body. In some cases a cell of the mesencephalic root of $\mathrm{V}$ which is provided with a short process gives origin also to the above-described long process. In the second layer a cell of the mesencephalic root of $V$ has been found, the one process of which runs to the inner border of the third layer and turns then in a longitudinal direction; the other process of this cell arising from the same pole of the cell body extends into the fourth layer and embraces there a cell of this layer. In one cell a quite thick process has been observed to arise from the cell body and to course toward the periphery of the tectum. In the fourth layer of Cajal this thick process becomes abruptly much thinner and is traceable so into the sixth layer-evidently it gives off branches in the fourth layer which turn out from the plane of the section. Another process from the same cell is thin. It runs to a small cell of the fourth layer, forms a small conic enlargement close to the cell body of the latter and divides into two branches which embrace the small cell on one side.

The mesencephalic root of $V$ of frog appears to be composed of those cell processes which enter the deep medullary layer. This is suggested by the appearance of the root fibers as well as their position with regard to the fibers of the deep medullary substance. In the tectum the fibers of the mesencephalic root of $\mathrm{V}$ probably run caudalward, medialward, and ventralward in close relationship with the fibers of the deep medullary layer. At the level of the torus semicircularis the mesencephalic root of $V$ has already become a distinct fiber bundle lying caudal to the torus semicircularis and frontal to the nucleus isthmi (fig. 3). In its course immediately cephalad to the latter the root lies in relation with the spinotectal path. The fiber bundles of the mesencephalic root of $\mathrm{V}$ swing ventral to the nucleus isthmi (fig. 3). Medial to the mesencephalic root of $V$ lies the trochlear root. The fibers of the mesencephalic root of $V$ can be easily recognized by their appearance. Having passed the region of the nucleus isthmi, the fibers of the mesencephalic root of $V$ run 
farther caudalward until near the level of the motor nucleus of $\mathrm{V}$. They cannot be traced fârther distalward in our material. According to van Valkenburg ('11), the mesencephalic root of $\mathrm{V}$ in frog runs caudalward to lie dorsomedial to the sensory root of $\mathrm{V}$ and intermingles with the fibers of the latter. C. J. Herrick ('14) has described in larval Amblystoma a bifurcation of the fibers of the mesencephalic root of $\mathrm{V}$ at the level of the motor nucleus of $\mathrm{V}$. The descending branches, arising by this bifurcation, can be followed caudalward to the level of the motor nucleus of VII, where they

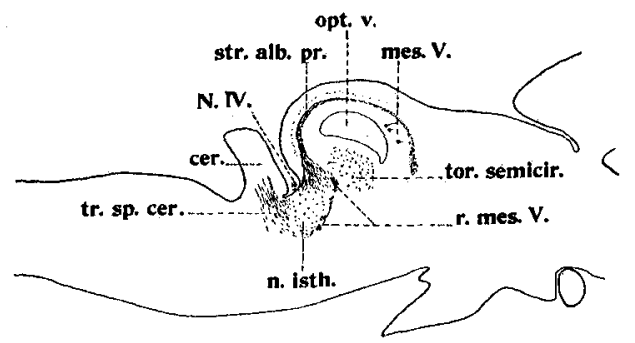

Fig. 3 Sagittal section through the midbrain of frog slightly lateral to the trochlear root. Chrom-silver preparation. $\times 10$. cer., cerebellum; mes.V., cells of the meseneephalic root of $\mathrm{V}$; n.isth., nucleus isthmi; N.IV., trochlear nerve; opt.v., optic ventriele; r.mes.V., the mesencephalic root of $\mathrm{V}$; str.alb.pr., stratum album profundum; tor.semicir., torus semicircularis; tr.sp.cer., tractus spinocerebellaris.

arborize among the dendrites of this nucleus. A fiber bundle of mesencephalic root of $V$ running caudalward to this level has been observed by Kingsbury ('95) in Necturus and by Norris ('13) in Siren. Furthermore, Herrick has described slender collateral branches to the motor nucleus of $\mathrm{V}$.

We could not obtain any certain evidence in the frog material that the fibers of the mesencephalic root of $\mathrm{V}$ enter the trochlear root, though such a possibility cannot be denied. After use of the intra-vitam methylene-blue method in Necturus, McKibben ('13) saw among the trochlear fibers certain fibers arising from the caudal border of the optic tectum and belonging seemingly to the mesencephalic root 
of $V$. These fibers seemed to enter the trochlear nerve uncrossed. Davidson Black ('17) and Larsell ('23) have likewise assumed that the trochlear root contains (in Rana catesbiana and Rana pipiens, respectively) fibers from the nucleus of the mesencephalic root of $V$. The latter bases his assumption on the occasional presence of some cells of the mesencephalic root of $\mathrm{V}$ in the neighborhood of the exit of the trochlear nerve. A very few fibers of an appearance similar to that of the fibers of the mesencephalic root of $V$ have been seen by us in the anterior medullary velum. These fibers appear to course from the caudal border of the tectum toward the exit of the trochlear nerve in a way similar to that described by McKibben. However, we cannot feel certain that they belong either to the mesencephalic root of $\mathrm{V}$ or to the trochlear nerve.

We have found no fibers of the mesencephalic root of $V$ of the frog entering the cerebellum. This agrees with the observations of Herrick ('14) with regard to Necturus. Larsell ('23) states that while his material suggested a relation of the mesencephalic root of $V$ to the cerebellar structures he was unable to obtain any clear evidence in support of such a statement. Likewise, there is no evidence in our material for a crossing of the fibers of the mesencephalic root of $V$. A partial crossing of these fibers has been observed by Herrick ('14) in Necturus.

\section{THE MESENCEPHALIC ROOT OF V IN REPTILES}

In the reptiles studied the nucleus of the mesencephalic root of $\mathrm{V}$ is situated, as in amphibians, in the region of the midbrain. In the forms studied by us cells of this nucleus have been observed in a lateral position-in the optic lobes, as well as in a medial position-in the roof of the aqueduct. The cells in the optic lobes are confined, as in amphibians, to the layers placed between the stratum album profundum and the ventricular cavity. However, a situation of the cells of the mesencephalic root of $V$ nearer to this stratum and thus further removed from the ependyma is more common in reptiles than in the frog. 


\section{The mesencephalic root of $V$ in the turtle}

In the turtle, as in amphibians, the cells of the mesencephalic root of $\mathrm{V}$ lie in the region of the optic tectum, but here, in addition to cells in the dorsomedial wall of the optic ventricle, a cell grouping is present in the median plane (fig. 4). The differentiation into two lateral and one unpaired medial group is quite clear in the turtle.

The lateral cells lie along the dorsomedial wall of the ventricular cavity of the tectum. Some of them are found in its caudal wall, but it is never possible to find these cells in the ventral wall. Occasionally, however, a few cells can

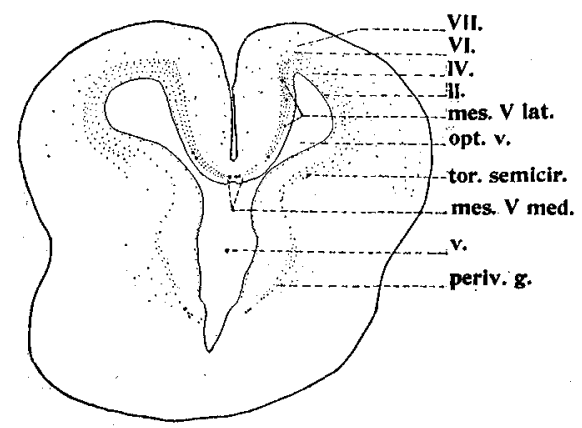

Fig. 4 Cross-section through the midbrain of turtle. Toluidin-blue preparation. $\times 10$. mes.Vlat., Iateral cells of the mesencephalie root of $\mathrm{V} ;$ mes. $\nabla m e d$, medial ceells of the mesencephalic root of $\mathrm{V}$; opt.v., optic ventricle; periv.g., periventricular gray; tor.semicir., torus semicireularis; $v$., ventricle; $I I$., $I V$., $V I ., V I I$. , layers of the tectum.

be distinguished in the medial part of the dorsolateral wall, not far lateral to the dorsomedial angle of the ventricle. The lateral cells begin frontally about $0.6 \mathrm{~mm}$. caudal to the frontal limit of the tectum, i.e., nearly at the same level at which the ventricular eavity of the tectum appears in crosssections. They extend back to the level of the caudal end of the trochlear nucleus. The nuclear cells extend slightly farther caudad $(0.04 \mathrm{~mm}$.) on one side than on the other. For the most part the cells are more or less distant from each other and, being situated in different layers of the optic 
tectum, are not arranged in a perfectly regular line (fig. 4). Near to the median plane the lateral cells lie, in general, in the fourth layer of Cajal. More laterally they reveal a certain tendency to migrate toward the more peripheral layers of the tectum (fig. 4). In the lateral half of the dorsomedial wall the cells lie in the fourth, fifth, and sixth layers and, rarely, even outside of the sixth layer-in the innermost part of the deep medullary layer.

The lateral cells are more or less oval in outline. Sometimes their pale process is directed toward the periphery of the tectum. The diameter of the lateral cells varies between $16 \mu$ and $33 \mu$, the average being $25 \mu$. The average diameter of the shorter axis is about $23 \mu$ and that of the longer about $27 \mu$ (table 2 ).

The medial cells are grouped directly in the median line and close to it on both sides ventral to the tectal commissure. They are almost twice as numerous as the lateral cells (table 1). They appear frontally about $0.4 \mathrm{~mm}$. caudad to the frontal end of the lateral cells or about $0.2 \mathrm{~mm}$. caudad to the frontal limit of the oculomotor nucleus and increase relatively quickly in number, so that beginning about $0.2 \mathrm{~mm}$. from the frontal pole of the medial group they are most numerous (about ten to thirteen cells in each cross-section) for a distance of about $0.24 \mathrm{~mm}$. in the longitudinal direction. Caudalward, about $0.45 \mathrm{~mm}$. from the frontal pole of this group, a slight decrease is evident. Another slight decrease begins approximately at the level of the caudal limit of the oculomotor nucleus. The medial cell group extends caudally to the level of the trochlear decussation. In the most caudal portion of the nucleus the cells are, however, very few in number.

The medial group has a less frontocaudal extension than the lateral group and reveals a slight swelling soon after its frontal beginning. This swelling extends to a distance of about $0.24 \mathrm{~mm}$. in the frontocaudal direction. Such an augmentation cannot be seen in the lateral group, where the cells are more scattered in the frontocaudal as well as in medio- 
lateral direction. The frontal portion of the medial nucleus appears, therefore, in horizontal sections as a quite massive nuclear group, situated in and close to the median line on both sides.

The cells of the medial group lie ventral to the tectal commissure, sometimes among its fibers. In a very few cases they are seen close to the ependymal cells of the aqueduct, but only in the most frontal part of the group. The usual arrangement is for a part of the central gray to lie ventral to the medial group, between the latter and the roof of the aqueduct. As seen in cross-sections, the medial cells lie mostly in a single layer, however, which does not always form a regular line, the individual cells being often situated at different distances from the roof of the aqueduct.

The cells of the medial group are more variable in size and shape than those of the lateral group. Their diameter varies between $11 \mu$ and $35 \mu$. On the whole they are smaller than the lateral cells, their average diameter being about $20.5 \mu$, that of their shorter axis $18 \mu$, and that of the longer $23 \mu$. The more frontally situated cells are, in general, slightly larger than the caudal ones. For the most part the medial cells are of an irregular, polygonal shape, sometimes bean-shaped, sometimes slightly elongated. The elongated form seems to be more conspicuous in sagittal sections, while the cross and horizontal sections reveal a more polygonal shape of the cells. In sagittal sections of the toluidin-blue material a cell process, extending dorsally toward the periphery of the tectum, can occasionally be seen. In horizontal and in cross sections of toluidin-blue preparations such processes of the medial cells cannot be recognized. Round cells of regular outline are much less frequent in the medial group than in the lateral. They are found most frequently in the caudal portion of the medial group and are of relatively small size in comparison with other cells of the group and with the cells of the lateral group.

An intermediate group cannot be easily distinguished in the turtle. The very few cells that sometimes lie at the 
transition of the aqueduct to the optic ventricle are entirely similar to the lateral cells in their arrangement with reference to the cell layers of the tectum, as well as in their shape and size. The situation of the nucleus of the mesencephalic root of $\mathrm{V}$ throughout the whole frontocaudal length of the tectum corresponds, in Chrysemys marginata, very nearly to the relations described by van Valkenburg ('11) for Varanus and Chelone midas. According to this observer, the medial cells of Chelone are most numerous in the cross-sections where the distal portion of the oculomotor nucleus is found. In the cross series of our Chrysemys material the main accumulations of the medial cells are found approximately at the level of the middle third of the oculomotor nucleus. At a level about $0.4 \mathrm{~mm}$. frontal to the caudal limit of this nucleus the number of cells begins to decrease. It is, however, greater than at the level of the frontal third of the oculomotor nucleus. In Chelone and Chrysemys the medial cells extend caudad to the caudal end of the trochlear nucleus. In Varanus, according to van Valkenburg, they are very few in number, so that they cannot be distinguished as a separate nucleus. The number of lateral cells, as compared with the number of the medial cells, is on the contrary relatively small in the Chrysemys material. This corresponds to the relations found by van Valkenburg in Chelone. Intermediate cells, as distinguished by this author in the latter, are practically not differentiable in our Chrysemys preparations. The shape of the medial cells seems to correspond in Chrysemys to that described and reproduced by van Valkenburg in the medial nucleus of Chelone.

The situation of the nucleus of the mesencephalic root of $\mathrm{V}$ in Chrysemys, Chelone, and Varanus differs much from that in Eunectus murinus, where, according to van Valkenburg, it is found almost exclusively in the caudal quarter of the tectum, the proximal end of the nucleus lying caudad to the posterior commissure at a distance that corresponds approximately to a quarter of the sagittal diameter of the tectum. The caudal end of the nucleus of the mesencephalic 
root of $\mathrm{V}$ corresponds in Eunectus, as approximately in Chrysemys, to the level of exit of the IVth nerve from its nucleus. The medial cells in Eunectus, as in Varanus, are very few in number. The size of the cells of the mesencephalic root of $V$ in reptiles is, in general, smaller in caudal portions of the nucleus (van Valkenburg). This is true in our Chrysemys material only with respect to the medially situated cells. In this medial group, in general, the round small cells are more numerous in the caudal part of the cell group than in the frontal. The cells of the lateral group do not reveal, however, such a difference in size. In Eunectus murinus the size of the rostral and caudomedial cells is said to be twice that of the caudolateral ones. The lateral cells of Chrysemys, in both frontal and caudal regions, are, in general, larger than the frontomedial cells. However, occasionally, scattered neurones of a size greater than that of the largest lateral cells are found among the frontomedial cells.

In chrom-silver preparations the cells of the mesencephalic root of $V$ are well impregnated and in many of them the processes are well shown. In lateral cells of the turtle, as in the frog, a cell process is often seen to enter the deep medullary layer. In sagittal sections occasionally at the inner border of this layer it can be observed to bend into a longitudinal direction. Rarely it divides in the stratum album profundum in a $\mathrm{T}$ - or $\mathrm{Y}$-shaped fashion into two branches. Sometimes it ramifies at a deeper level into two or more branches, of which not all reach the deep medullary substance. In addition to this process, which is directed toward the periphery of the tectum, some cells are provided with one or two processes, which arise either from the same or from the opposite pole of the cell body. These processes are often directed inward. In many cells only the inward-directed processes are shown. They arise sometimes as thick processes from the cell body and ramify then into several very delicate branches, which end in the fifth, fourth, or third layer. Basket-like contacts with the small tectal neurones, 
as seen in the frog, are not observed in our turtle material. Sometimes the two or three processes arise from the cell body and course inward in a fork-like fashion. Often the inwardly directed processes or their slender branches bend in the third layer into a direction parallel to the ventricular cavity. A T-shaped division is sometimes observable in the third layer. The medial cells of the mesencephalic root of $\mathrm{V}$ are more frequently multipolar than are the lateral ones. This is especially the case with the caudomedial cells. Often one process of the medial cells is sent dorsalward through the tectal commissure. It is usually inclined slightly frontalward. In general, the process is not traceable far outward from the outer border of the commissure. Occasionally, however, it approaches very near the optic layer. Sometimes the process ramifies just above the commissure into two branches. A very few cells are seen above the commissure. Their single processes are also directed frontodorsalward. In some cells more than one process arises from the same pole of the cell body and passes dorsalward through the tectal commissure. In some cells one process is directed into the tectal commissure, while one or more other processes scatter out in the deepest cell layer, after having undergone a splitting into several slender branches. In the sagittal series of our turtle material a few cells are present in the anterior medullary velum in a very intimate relationship with the decussating trochlear fibers. In one of these cells the process is seen to divide into two branches, of which one lies very close to the trochlear fibers.

In the turtle, as in the frog, the mesencephalic root of $\mathrm{V}$ is apparently formed by those cell processes which enter the deep medullary layer. The root is situated caudal to the corpus quadrigeminum posterius (or torus semicircularis) inside of the deep medullary layer and in a quite close relationship with the spinotectal tract (fig. 5). The root descends in a ventrocaudal direction to the level of the nucleus isthmi, and lies then between this nucleus and the trochlear root. The most medial fibers of the mesencephalic root of $V$ turn 
slightly lateralward just in front of the trochlear decussation in order to pass lateral to the trochlear root. Having passed the region of the nucleus isthmi, the mesencephalic root of $\mathrm{V}$ turns slightly lateralward and then runs in a caudal direction in order to reach the region of the motor nucleus of $\mathrm{V}$ (fig. 6). In the region of the anterior medullary velum the mesencephalic root of $\mathrm{V}$ lies ventral to the decussatio veli.

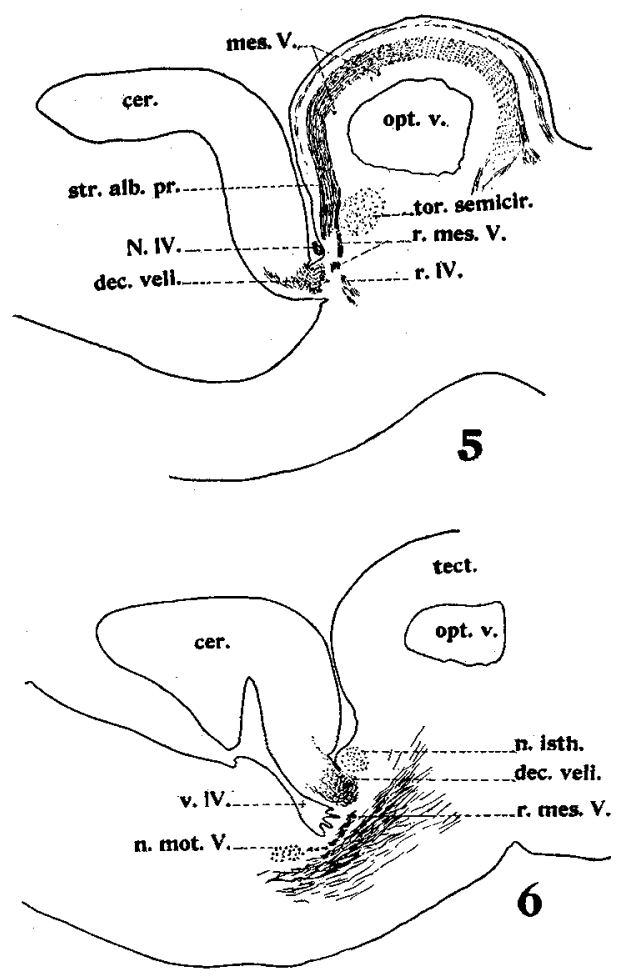

Fig. 5 Sagittal section through the midbrain of turtle at the level of the trochlear root. Chrom-silver preparation. $\times 10$. cer., cerebellum; dec.veli., decussatio veli; mes.V., cells of the mesencephalic root of $\mathrm{V} ; N . I V$., trochlear nerve; opt.v., optic ventricle; r.IV., trochlear root; r.mes.V., meseneephalic root of $\mathrm{V}$; str.alb.pr., stratum album profundum; tor.semicir., torus semicireularis.

Fig. 6 Sagittal section through the midbrain and pons of turtle at a level lateral to the trochlear root. Chrom-silver preparation. $\times 10$. cer., cerebellum; dec.veli., decussatio veli; n.isth., nueleus isthmi; n.mot.V., motor nucleus of $\mathrm{V}$; opt.v., optic ventricle; r.mes.V., mesencephalic root of $\mathrm{V}$; tect., tectum; v.IV., fourth ventricle. 
In this region a bundle detaches itself from the root and runs dorsalward toward the cerebellum, swinging around the ventrocaudal border of the decussatio veli. It would seem that at least some fibers of this bundle originate by splitting from the main fibers of the mesencephalic root of $V$. Just in front of the motor nucleus of $\mathrm{V}$ very fine branches are given out from the fibers of the mesencephalic root of $V$. Dorsal to the motor nucleus of $\mathrm{V}$ the fibers of the mesencephalic root of $V$ disperse and turn ventralward. They probably intermingle with the fibers of the motor root of $V$.

The mesencephalic root of $V$ in the alligator

The optic tectum in the alligator is of a relatively great size and, as has been pointed out by Huber and Crosby ('26), has reached a high degree of development and differentiation in its cellular layers. The optic ventricles extend lateral and dorsal, ventral and rostral from the aqueduct, as in the turtle, but the lateral extension of the ventricle is much more pronounced in the alligator than in the turtle. Also, in the former the ventricular cavity is diminished greatly by the bulging of the torus semicircularis (the probable homologue of the corpora quadrigemina posteriora) into the ventricle.

In Alligator mississippiensis, the cells of the mesencephalic root of $\mathrm{V}$ are found around the whole ventricular cavity of the optic tectum, on all its walls with the exception of the region occupied by the torus semicircularis. The nucleus reveals a considerable development and the number of its cells is relatively high-more than five times that in the turtle (table 1). A lateral and a medial cell group are very clearly distinguishable in the alligator. In addition to these, a less distinct intermediate group can be recognized (van Valkenburg, '11). These groups are shown in figures 7,8 , 9 , and 10.

The lateral cell group (figs. 8, 9, and 10) is situated along the walls of the optic ventricle. It begins $0.2 \mathrm{~mm}$. in front of the cephalic pole of the ventricular cavity of the tectum. The main masses of the lateral cells are found in the dorso- 
medial wall of the optic ventricle. Many cells are located, however, in its lateral wall and in the caudal part of the tectum a very few of them lie even ventral to the ventricle. Many cells are seen also in the frontal as well as in the caudal wall. The lateral part of the nucleus of the mesen-
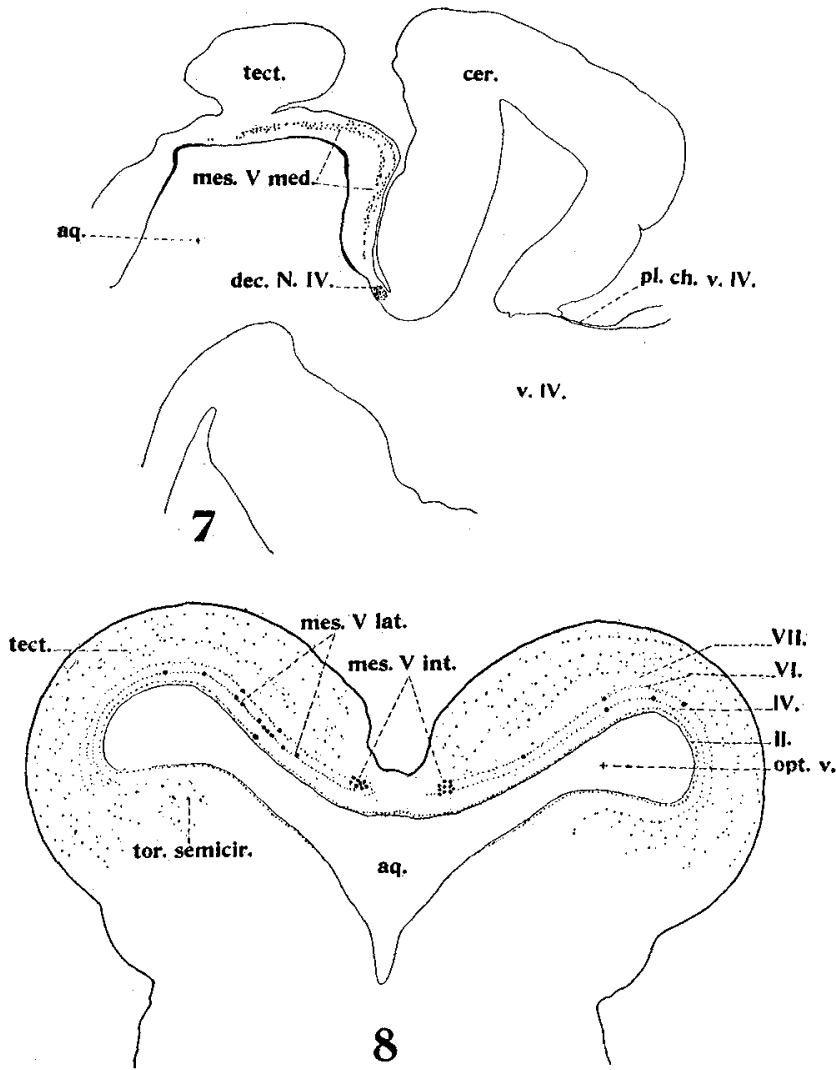

Fig. 7 Sagittal section through the midbrain of Alligator mississippiensis near the median plane. Toluidin-blue preparation. $\times 10$. aq., aqueduct; cer., cerebellum; dec.N.IV., decussation of the trochlear nerves; mes.Vmed., medial cells of the mesencephalie root of $\mathrm{V}$; pl.ch.v.IV., plexus choroideus ventriculi quarti; tect., tectum; v.IV., fourth ventricle.

Fig. 8 Cross-section through the midbrain of Alligator mississippiensis at the level of the frontal portion of the nucleus of the mesencephalie root of $V$. Toluidin-blue preparation. $\times 10$. aq., aqueduct; mes.Vint., intermediate cells of the mesencephalic root of $\mathrm{V}$; mes.Vlat., lateral cells of the mesencephalic root of $\mathrm{V}$; opt.v., optic ventricle; tect., tectum; tor.semicir., torus semicireularis; $I I ., I V ., V I ., V I I .$, layers of the tectum. 
cephalic root of $\mathrm{V}$ thus surrounds almost the whole ventricular cavity of the tectum. The region of the tectum, where the torus semicircularis is situated, is free from the cells of the mesencephalic root of $\mathrm{V}$, although occasionally single cells are found very close to the torus. This situation of the lateral group is somewhat different from that in the turtle

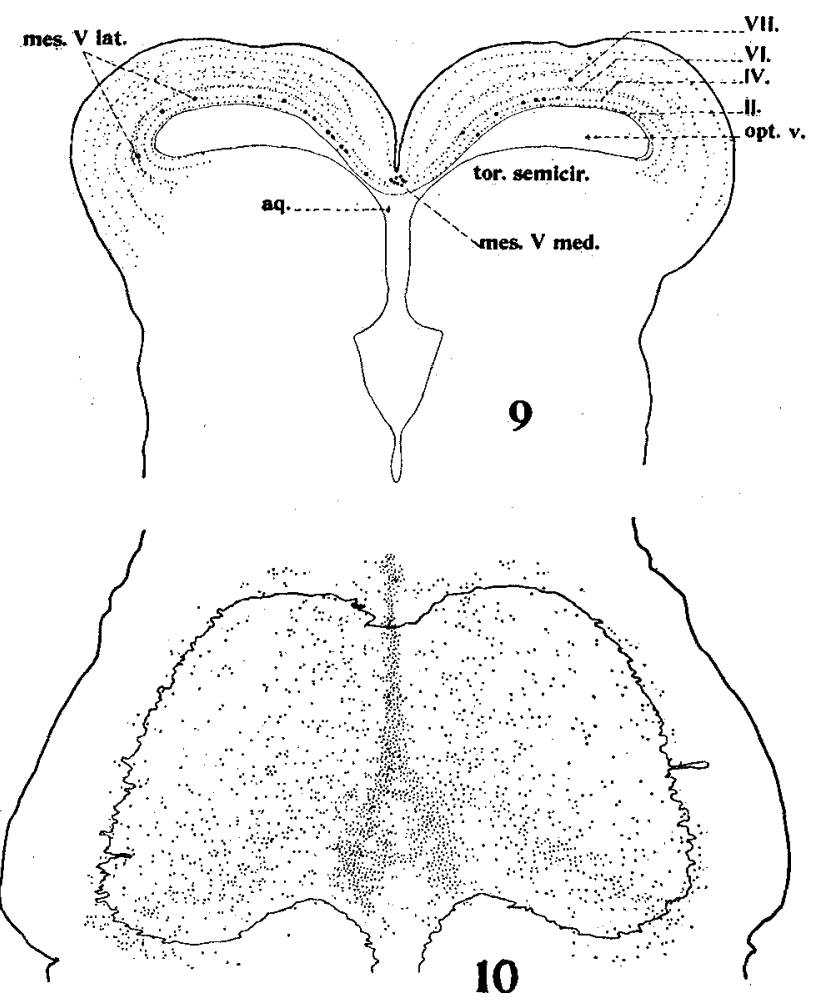

Fig. 9 Cross-section through the midbrain of Alligator mississippiensis at the level of the caudal portion of the nucleus of the mesencephalie root of $V$. Toluidin-blue preparation. $\times 10$. aq., aqueduct; mes.Vlat., lateral cells of the mesencephalic root of $\mathrm{V}$; mes.Vmed., medial cells of the mesencephalic root of $\mathrm{V}$; opt.v., optic ventricle; tor.semicir., torus semicircularis; $I I ., I V ., V I ., V I I$., layers of the tectum.

Fig. 10 Graphic reconstruction of the nucleus of the mesencephalic root of $\mathrm{V}$ of Alligator mississippiensis. The outlines of the nuclear masses and of the ventricles are projected on a horizontal plane. $\times 10$. The outer (thicker) line indicates the outline of the tectum; the inner (thinner) line indicates the outline of the optic ventricles. The dots represent the cells of the mesen. cephalic root of $V$. 
where the cells can be found mainly in the dorsomedial wall of the optic ventricle.

Another characteristic difference in the lateral group of cells of the nucleus of the mesencephalic root of $\mathrm{V}$ in the alligator as compared with that in the turtle is the arrangement of the cells in the layers of the tectum. In the turtle the more medially lying cells are found generally in the fourth layer of Cajal, while the more lateral ones manifest a tendency to lie in more peripheral layers of the tectum. In the alligator such an arrangement cannot be observed. The more medially situated of the lateral cells lie sometimes in the fifth and sixth layers of Cajal. More laterally the cells are often found in the fourth layer. Generally the cells of the lateral group in the alligator are far removed from each other and located in the fourth to sixth layers. Sometimes single cells can be observed very close to the ependymal layer of the dorsomedial wall of the ventricle. These latter are much smaller in size than the other lateral cells.

The lateral cells extend to near the level of the trochlear decussation or about $0.2 \mathrm{~mm}$. caudal to the optic ventricle (fig. 10). The cells are in general more numerous in the rostral portion of the nucleus, the increase beginning approximately $0.3 \mathrm{~mm}$. from the rostral end of that cell mass (as determined by serial-cell count, giving five to eight cells for each cross-section on either side). They become more scarce in the caudal portion of the tectum, but, in spite of their greater number in rostral parts, the individual cells are not closer to each other. This is partly due to a greater lateral extension of the tectum cephalad and partly to the fact that the cells there frequently lie in the lateral and ventral wall of the ventricle, while in caudal parts they are more strictly confined to the mediodorsal wall.

The position of the nucleus of the mesencephalic root of $\mathrm{V}$ in the Alligator mississippiensis corresponds on the whole to that in the Alligator sclerops, as this is described by van Valkenburg ('11). According to this author the medial cells are, in general, smaller in size than the lateral and inter- 
mediate ones. The medial cells are in a closer relation to each other. However, the number of cells, especially of those of the medial group in its caudal portion, is greater in our material of Alligator mississippiensis than is given in the table of van Valkenburg. Also, in our preparations the greatest number of cells is found in the region of the oculomotor nucleus, while, according to van Valkenburg, this is observed in the Alligator sclerops rostral to this region.

The intermediate group can be distinguished in the Alligator mississippiensis only in the rostral portion of the tectum. This group can be considered as a lateral extension of the medial group in the frontal portion of the nucleus of the mesencephalic root of $V$, since the whole nucleus reveals, in its caudal portion, a tendency to approach the median line (fig. 10).

The cells of the intermediate group (figs. 8 and 10) lie medial to the lateral group among the fibers of the commissura colliculi superioris, chiefly between the latter and the roof of the aqueduct or the communication of the latter with the optic ventricle. In its rostral portion the intermediate group is farther removed from the median line than in the caudal levels. Sometimes the intermediate cells lie close to the lateral ones; however, they are, in general, easily distinguishable from the latter by their size and arrangement. The intermediate cells lie more close to each other, being gathered together into a quite well differentiated nuclear mass and forming no distinguishable cell layers. Though situated sometimes very near to the roof of the aqueduct, the intermediate cells are in general not found close to its ependymal cells.

The intermediate nucleus begins about $0.2 \mathrm{~mm}$. caudal to the lateral nucleus. Caudally the intermediate nucleus approaches more and more the median line and at last lies in so close a relation to the medial nucleus that it is very difficult to distinguish it from the latter (fig. 10). About $1.6 \mathrm{~mm}$. caudad to the rostral limit of the lateral nucleus of the mesencephalic root of $\mathrm{V}$ the intermediate nucleus can no longer be 
differentrated. In this region the medial nucleus is just becoming conspicuous. Thus, the intermediate nucleus does not have any considerable frontocaudal extent, being limited to about $1.4 \mathrm{~mm}$. The lateral group extends in frontocaudal direction to a distance of about $3.2 \mathrm{~mm}$. Its mediolateral extent is likewise much greater than that of the intermediate nucleus.

The medial nucleus of the mesencephalic root of $\mathrm{V}$ (figs. 7, 9 , and 10) is an unpaired cell group, lying in the median line and close to it on both sides. It begins about $0.5 \mathrm{~mm}$. caudal to the frontal limit of the intermediate group. The cells are relatively numerous in the frontal part of the medial nucleus (for a distance of about $0.3 \mathrm{~mm}$.). Through this region from four to seventeen cells can be found in each cross-section. Then they become less numerous for a distance of about $0.6 \mathrm{~mm}$., where in some sections they are even lacking. At a level of termination of the intermediate nucleus, the medial cells again are more numerous and keep a relatively constant number of cells (about five to eight cells per section) until the caudal end of the nucleus. The cells of the medial nucleus are situated relatively close to each other. Like the intermediate cells, they are found ventral to the fibers of the commissura colliculi superioris and are not present near the ependymal layer of the aqueduct. In a more caudal region the medial cells lie in the anterior medullary velum and can be seen down to the beginning of the decussation of the trochlear nerve (fig. 7). They extend distalward from the caudal limit of the lateral cells for a distance of about $0.1 \mathrm{~mm}$.

The cells of the lateral nucleus differ in shape and size from those of the intermediate and medial ones. Their average diameter is about $23 \mu$, that of the intermediate cells about $16 \mu$, and that of the medial about $16 \mu$. The lateral, as well as the medial cells, are, on the average, smaller than the corresponding cells in the turtle (table 2). This difference is especially striking with respect to the medial cells, which are of particularly small size in the alligator. The term 
'vesiculoid,' which has been used by some authors, might be applied only to the lateral cells, which are usually more or less rounded; the predominate outline of the intermediate cells seems to be a smaller, round, or oval one, while that of the medial is apparently polygonal. The size of the lateral cells in the alligator is less constant than in the turtle, a relatively large number of small cells being found in the former. The intermediate and especially the medial cells are often stained very deeply and diffusely in toluidin-blue preparations. This is very rarely the case with the lateral ones, in which the tigroid granulations are well seen. The most frontal of the intermediate cells approach in form the lateral cells, while the most caudal resemble more closely the medial ones. However, in Alligator mississippiensis there is not evident a difference in size between the more frontally and the more caudally situated cells of the nucleus of the mesencephalic root of $\mathrm{V}$.

In chrom-silver preparations the cells of the mesencephalic root of $V$ are not well impregnated. In some of them, nevertheless, there can be observed, as in the turtle, a process directed toward the periphery of the tectum into the deep medullary layer. The other one or two processes arise from the opposite pole of the cell and are seen to run for a short distance in the fourth layer of Cajal. Sometimes small branches can be seen originating from the longer process, while the shorter often ramifies in several fine branches.

The fibers of the mesencephalic root of $V$ leave the tectum opticum to descend behind the corpora quadrigemina posteriora. They are arranged in small bundles which run medialward, ventralward, and quite slightly caudalward. Having thus reached the ventral border of the corpora quadrigemina posteriora, the fibers of the mesencephalic root of $V$ turn caudalward, keeping at the same time a slightly ventral direction. They arrive at the level of the decussation of the trochlear nerve and then the main fiber masses turn, as they run in caudal direction, lateralward and more directly ventralward to pass between the nucleus isthmi and 
the trochlear root, the former lying lateral and the latter medial to the mesencephalic root of $V$. Ventromedial to the mesencephalic root of $\mathrm{V}$ runs the cerebellotegmental tract and lateral to it the vestibulocerebellar tract (Huber and Crosby, '26). In the region of the cerebellum some few fibers run dorsalward for a short distance, lying ventrocaudal with reference to the decussatio veli. Soon they turn lateralward. In following these fibers farther in the sagittal series they can be seen to bend again ventrocaudalward in order to join the main fiber masses of the root. It is not possible to determine in the material available whether or not some branches are given off to the cerebellum from these dorsalwarddeviating fibers of the mesencephalic root of $V$. However, their course itself seems to suggest such a possibility. From the region of the decussatio veli the mesencephalic root of $\mathrm{V}$ runs farther in a ventrolateral and caudal direction and arrives at the level of the motor nucleus of $V$. In the region of the pons the mesencephalic root of $V$ lies close to the dorsolateral angle of the IVth ventricle. It passes on the lateral side of the motor nucleus of $\mathrm{V}$ between the motor and sensory roots of the $V$ th nerve. Whether the fibers of the mesencephalic root of $\mathrm{V}$ join the motor or the sensory fifth root cannot be decided with certainty. The fibers of some of the frontally lying cells of the nucleus of the mesencephalic root of $V$ run caudalward, passing ventral to the corpora quadrigemina posteriora and dorsal to the fibers of the radiation of Meynert. We are unable to show, however, the further course of these fibers, although the supposition is that they are following this more direct course in order to join the root.

THE MESENCEPHALIC ROOT OF $V$ IN BIRDS

In birds, as in reptiles and in the frog, the nucleus of the mesencephalic root of $\mathrm{V}$ is confined to the region of the optic tectum. The cells extend in birds caudalward to the level of the decussation of the trochlear nerve. This is in accordance with the observations on the turtle and on the alligator. 
Due to the fact that the avian optic tectum has undergone a lateral displacement so that the dorsolateral wall of the optic ventricle of birds is the dorsomedial wall of reptiles, a part of the cells of the nucleus of the mesencephalic root of $\mathrm{V}$ are dorsolateral in position in birds, while in reptiles they are mostly dorsomedial. Moreover, several elements of the tectum which in the frog and in reptiles lie inside of the deep medullary layer, between the latter and the ependyma, are situated in birds outside of the deep medullary layer. In birds, between the ependyma and the deep medullary substance, only one layer (the fifteenth ${ }^{5}$ ) has been distinguished by P. ('98) and S. ('09) Ramón y Cajal. In our bird material this fifteenth layer of Cajal is easily separable into two layers. The one of the subdivisions of the fifteenth layer lies immediately outside of the ependyma ( $X V b$., figs. $12,13,17$ ) and is composed chiefly of fine nerve fibers. The other lies immediately at the inner border of the deep medullary layer and contains a great number of small nerve cells ( $X V a$., figs. $12,13,17$ ). It is in this latter layer, among the small cells and close to the inner border of the deep medullary layer, where in birds the lateral cells of the mesencephalic root of $V$ are located. Such a position has invariably been observed by us in birds. In frog and reptiles the cells of the mesencephalic root of $\mathrm{V}$ lie also always inside of the deep medullary layer, but they are here not so definitely confined to the inner border of this layer, being found at different distances between the ventricular cavity and the stratum album profundum and usually more or less removed inward from the latter.

\section{The mesencephalic root of $V$ in the chicken}

In the chicken the cells of the nucleus of the mesencephalic root of $V$ can be separated into two groups: a medial group

${ }^{5}$ In birds P. ('98) and S. ('11) Ramón y Cajal enumerate the tectal layers from without inward-thus in a sense inverse to the enumeration adopted by them for reptiles and frog. Accordingly, the enumeration employed by us in the description of the nucleus of the mesencephalie root of $\mathrm{V}$ in birds is inverse to that used in the description of this nucleus in reptiles and frog. 
situated in the roof of the aqueduct and a lateral one in the optic lobes. The frontal limits of the medial group correspond to those of the tectal commissure, while the medial cells are found on either side very close to the midline. A few of them are present in the midline. In frontal portions of the nucleus the cells lie at quite a distance from the roof of the aqueduct, lying between the dorsal and ventral parts of the posterior commissure and in part between the fibers of the dorsal portion. More caudalward, they approach the aqueduct and lie ventral to the tectal commissure, close to

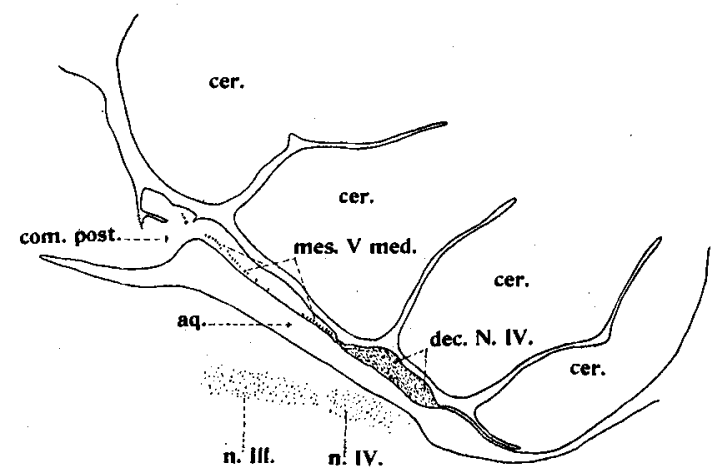

Fig. 11 Sagittal section through the midbrain of chicken near the median plane. Toluidin-blue preparation. $\times 10$. aq., aqueduct; eer., cerebellum; com.post., commissura posterior; dec.N.IV., decussation of the trochlear nerves; mes.Vmed., medial cells of the mesencephalic root of $\mathrm{V}$; n.III., oculomotor nucleus; n.IV., trochlear nucleus.

the ependymal cells of the ventricular roof. They .extend caudalward to the level of the trochlear decussation. In general, the medial cells are relatively close to each other. Only in the caudal three-fourths of the nucleus (fig. 11) do they become less numerous. Just in front of the trochlear decussation their number increases again.

The cells of the lateral group begin frontally at about the same level as those of the medial group. They are found in the dorsolateral wall of the optic ventricle, lying on the external border of the fifteenth layer of Cajal. We have never seen them in other layers of the optic tectum. The lateral cells are much farther apart than the medial ones. 
In single sagittal sections they lie in a curved line which follows the outline of the ventricular cavity. The concavity of this curved cell line is directed ventralward and caudalward in the more lateral regions and ventralward and frontalward in the medial regions. The greater number of the lateral cells are found in the caudal half of the optic lobe, some of them lying even in the caudal wall of the ventricular cavity, so that the cell line surrounds the caudal pole of the optic ventricle in these regions. In the frontal half of the optic lobes the cells of the mesencephalic root of $\mathrm{V}$ are much less numerous. They have never been observed frontal to the anterior pole of the ventricular cavity.

The cells of the medial group are of a polygonal and elongated shape, the longer axis of the cells being oriented in a frontocaudal direction, less frequently in a transverse direction. The average length of the shorter diameter is about $18 \mu$, while that of the longer diameter is $25 \mu$ (table 2 ). In toluidin-blue preparations they appear deeply and diffusely stained, so that tigroid granules are not easily distinguishable. The lateral cells have an oval outline. These cells are larger and less elongated than the medial cells; the average length of their shorter diameter is $27 \mu$ and that of the longer, $31 \mu$. The longer axes of the lateral cells are sometimes oriented in a frontocaudal direction, but this orientation is here less frequent than in the medial cells. They are not stained so diffusely as are the medial cells. Instead, large clumps of tigroid substance are found through the whole cell body, concentrically arranged around the nucleus. In many of the lateral cells a process directed toward the periphery of the optic tectum can be observed in the sagittal sections of toluidin-blue preparations. In some of the cells, in addition to this process, there are one or two shorter processes. The process directed toward the periphery is sometimes seen to give origin to one or two lightly stained, slender branches. Often it can be traced for quite a distance from the cell body. The other processes are large and short, stain more deeply than the long process, and con- 
tain Nissl granules. They are usually directed toward the optic ventricle, but sometimes extend caudalward or frontalward. In toluidin preparations processes can be seen also in medial cells. One of the processes is long, homologous with the similar process in the lateral cells. Usually it is directed caudalward, sometimes frontalward. The other processes are short, but have a large diameter. They likewise may be directed either caudalward or frontalward. In some cells, besides these two kinds of processes, there are very fine and short processes which arise directly from the cell body and which become very delicate before their termination. These fine and short processes, like the long ones, appear pale.

\section{The mesencephalic root of $V$ in the duck}

In the duck, as in the chicken, the cells of the nucleus of the mesencephalic root of $V$ are in the optic lobes and in the roof of the aqueduct (fig. 12). The optic ventricle is a narrow space which presents in cross-sections an approximately semilunar form, with the concavity directed medialward and ventralward, the medioventral wall being occupied in part by the lateral mesencephalic nucleus. The lateral group of cells of the nucleus of the mesencephalic root of $\mathrm{V}$ (fig. 12) are found without exception at the inner border of the deep medullary layer of the optic lobes and mainly in the dorsolateral wall of the ventricular cavity. The extent of the lateral cells corresponds practically to that of the optic ventricle, but none is found in its medial or ventral wall. As the stratum of fine fibers, which lies close to the ependyma in the fifteenth layer of Cajal, is quite large in the duck, the cells of the lateral portion of the nucleus of the mesencephalic root of $\mathrm{V}$ come to lie quite far from the ventricular cavity. They are scattered throughout the whole length of the lateroventral extension of the optic lobes; however, the number of cells in any cross-section of the most frontal part of the nucleus is small (from one to five cells on either side, as per serial count). The lateral cells extend farther rostral than 
do the cells of the medial group found in the roof of the aqueduct. The frontal limit of the lateral group corresponds nearly to that of the frontal pole of the optic ventricle, i.e., about $2.8 \mathrm{~mm}$. caudal to the frontal pole of the optic lobe and about $1.5 \mathrm{~mm}$. frontal to the level of the frontal end of the oculomotor nucleus. In this region, as mentioned, only single cells are found. At the level of the rostral limit of

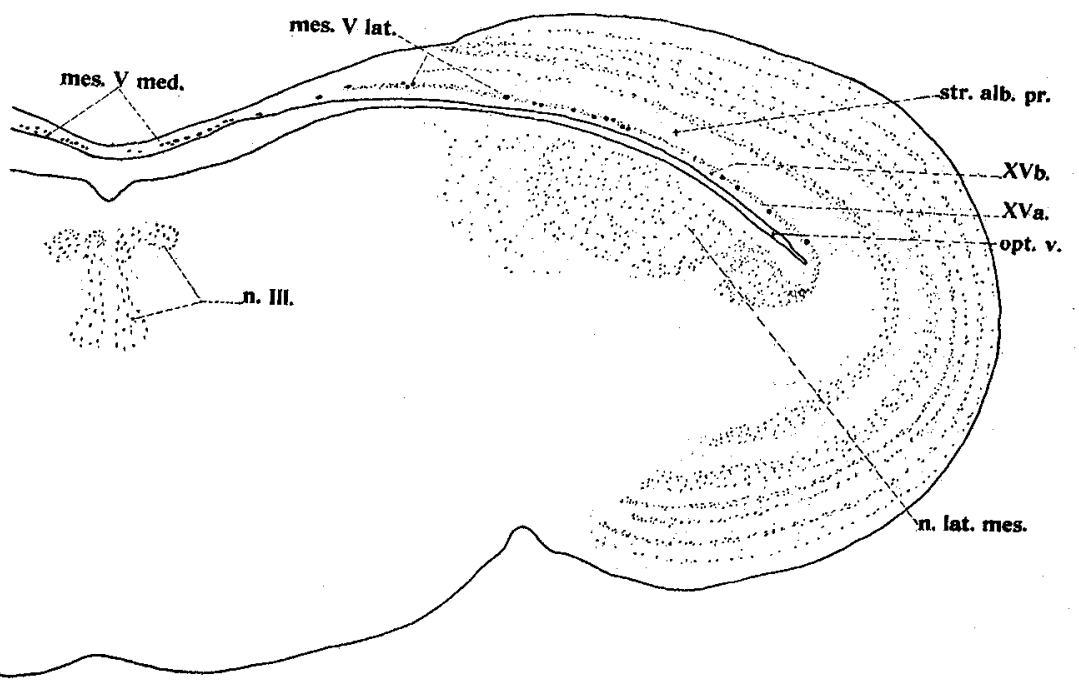

Fig. 12 Cross-section through the midbrain of duck at the level of the oculomotor nucleus. Toluidin-blue preparation. $\times 10$. mes.Plat., lateral cells of the mesencephalic root of $\mathrm{V}$; mes.Vmed., medial cells of the mesencephalic root of $\mathrm{V}$; n.III., oculomotor nucleus; n.lat.mes., nueleus lateralis mesencephali; opt.v., optic ventricle; stralb.pr., stratum album profundum; $X V$ a., cells of the fifteenth layer of Cajal; $X V b$., fibers of the fifteenth layer of Cajal.

the oculomotor nucleus, the lateral cells of the nucleus of the mesencephalic root of $\mathrm{V}$ become more numerous (increasing to twenty cells in each cross-section on either side), but they still remain far apart. Here, with the enlargement of the optic lobes, the cells extend in lateroventral direction from near the midline. About $0.6 \mathrm{~mm}$. farther caudal the number of lateral cells in each cross-section decreases slightly. The frontocaudal extension of the lateral group corresponds 
nearly to the longitudinal extent of the optic ventricle. Their caudal end is about $0.4 \mathrm{~mm}$. frontal to the caudal end of the trochlear nucleus. They thus extend, in frontocaudal direction, to a distance of about 3 to $3.5 \mathrm{~mm}$.

The medial cell group (fig. 12) is located in the roof of the aqueduct, the cells lying in more frontal regions among the fibers of the posterior commissure and farther caudad, ventral to those of the tectal commissure, sometimes quite close to the ependymal cells of the aqueduct. The frontal limit of the medial group corresponds nearly to that of the oculomotor nucleus, i.e., about $1.7 \mathrm{~mm}$. caudal to the beginning of the lateral group, and at the level (in cross-sections) where the aqueduct is passing over into the optic ventricles. In this place the separation of the lateral group from the medial becomes somewhat difficult, the cell line in the wall of the optic ventricle being continued without interruption with the cell group in the roof of the aqueduct. The slightly curved cell line of the lateral group makes a more abrupt turn medialward just above the communication of the aqueduct with the optic ventricle and here the lateral cells are also more numerous and lie closer to each other. At the same place, the medial cells extend farther lateralward, some of them lying in the periventricular gray of the ventricle, dorsal to the ventricle. About $0.4 \mathrm{~mm}$. farther caudalward the lateral and medial cell groups are easily distinguishable from each other, the cell line being clearly discontinued in the region of the transition of the aqueduct into the optic ventricle.

The arrangement of the medial cells is somewhat different from that of the lateral ones (fig. 12). While the latter are arranged in one layer, thus forming a single line, the medial cells appear, in cross-sections, as lying in two or three layers and frequently form a nuclear group without any regular arrangement within layers. The number of the medial cells is relatively high, to the extent of approximately eighty cells per section, from almost the beginning of the medial nucleus to a distance of about $0.5 \mathrm{~mm}$. in longitudinal direction. This 
augmentation of the medial group is evident only slightly farther caudal (from two to three sections) than the region where the increase in number of the lateral cells is noted. About $0.6 \mathrm{~mm}$. from the rostral beginning of the oculomotor nucleus the number of the medial cells begins to decrease, and the cells are less numerous for a distance of about $1 \mathrm{~mm}$. (about thirty cells in each section), at which level the lateral cells disappear and the optic ventricle begins to close. At a level which corresponds approximately to the frontal end of the trochlear nucleus, the cells of the medial group again become more numerous, increasing to approximately ninety cells in each section. Near the caudal end of the IVth nucleus, the medial group begins to diminish and disappears entirely about $0.25 \mathrm{~mm}$. caudal to this nucleus. The medial group extends thus from the frontal end of the oculomotor nucleus to the caudal end of the trochlear nucleus. The cells in the frontal portion of the medial nucleus are situated ventral to the dorsal part of the posterior commissure and, more caudally, ventral to the tectal commissure. The frontocaudal extension of the medial nucleus is about $2.4 \mathrm{~mm}$. This nucleus extends farther caudal than the lateral by about $0.7 \mathrm{~mm}$. The medial group reveals two enlargements-one just at its beginning at the level of the frontal end of the IIIrd nucleus, and another beginning in the region of the frontal limit of the trochlear nucleus where the lateral cells disappear. This latter augmentation ends quite closely frontal to the trochlear decussation. The more frontal cells of the medial group lie away from the ependymal layer of the aqueduct, while in more caudal portions, they often lie very close to the ependymal cells.

Three kinds of cells can be distinguished in the nucleus of the mesencephalic root of $\mathrm{V}$ in the duck (fig. 34) : a polygonal, an elongated, spindle-shaped form, and one with an oval outline. The oval or nearly round type (fig. $34, a$. and $b$.) predominates in the lateral group, while the medial group is composed mostly of the cells of the other two types. The oval or round cells of the lateral group are much larger than 
the cells of the medial group, the average diameter of the former being about $31 \mu$ and that of the latter, about $25.9 \mu$. The medial cells are, in general, much more elongated than the lateral, the difference between the longer and the shorter axes being on an average nearly $20 \mu$ for the medial cells and $12 \mu$ for the lateral. The lateral cells lie with their longer axis extending in a lateromedial direction; the medial usually have a similar orientation, but this is not invariably the case. The lateral cells have a more nearly smooth outline, their size is, in general, more constant than that of the medial cells. In the lateral cells are found relatively large clumps of tigroid substance in concentric rings around the nucleus. Sometimes it has been possible to see in these cells relatively large processes containing tigroid. Usually but one process can be observed and this is directed outward toward the periphery of the optic lobes. In some few cases the process divides into two thin branches also containing tigroid. In cells lying nearer to the median line the direction of the processes is dorsomedialward. More rarely, there are two or three large processes containing tigroid. In the most frontal portion of the medial group the cells resemble those of the lateral group, but this is true in our material for only the four sections which pass through the most frontal levels of the medial group. By the time the fourth section through the medial group is reached, somewhat different cells appear, which are situated more ventral and nearer to the roof of the aqueduct. These cells are of a more elongated spindle shape (fig. 34, a.). The body of these cells appears darker and the tigroid granules lie closer to each other, so that sometimes the cell seems to be stained diffusely, since the pale spaces between the tigroid substance almost entirely disappear. Very often in these cells two processes are seen emanating from the two opposite poles of the cell body; both processes are deeply stained and one is directed medialward, the other lateralward, the longer axis of the cell being oriented in a transverse direction. Beside these spindleshaped, deeply stained cells, cells of a polygonal shape are 
also found in the medial group (fig. 34, $a^{\prime}$.). They differ from the other cells in having a less pronounced elongation of their cell body and sometimes a relatively greater size. Their tigroid is more pale than even in the lateral cells, and the tigroid masses are not so close together. They differ further from the lateral cells in having a less regular shape. The size of these pale cells is variable, sometimes they are even larger than the lateral cells. The relatively greater number of the large cells is in the frontal portion. In the duck an intermediate group cannot be distinctly separated. However, a hint of such a group is given by certain medial cells which lie in the region of the dorsolateral angle of the aqueduct, partly among the fibers of the commissures of the tectal regions, partly in the periventricular gray. These cells are of the same dark, spindle-shaped type as those which are found in the ventral part of the medial nucleus. They are seen as far caudad as the medial group. In caudal portions they are the more easily distinguishable from the medial cells, since the spindle-shaped type among the latter are less numerous in this region. Also in the caudal end of the nucleus of the mesencephalic root of $\mathrm{V}$ there are 'intermediate' cells lying lateral to the lateral angle of the ventricle. The rest of the medial group lies in the roof of the ventricle. The cells of the 'intermediate' group are not numerous (from three to six in each section), and in the serial counts which have been made they were included in the number of the medial cells.

The average size of cells is greater in the duck than in the chicken, especially as regards the medial cells. This greater average of size is due to the fact that the medial group in chicken, for the most part, is composed of cells similar in form and size to the elongated spindle-shaped type. The proportional number of such spindle-shaped cells is less in the duck. The number of the cells in the mesencephalic root of $\mathrm{V}$ in the duck is nearly the same as in the chicken (table 1). However, a quite evident difference exists between the duck and chicken in respect to the relation between the 
cell number of the medial and lateral group; i.e., in the chicken the lateral and medial groups are almost equally developed (the relation of the number of the lateral cells to that of the medial being about $1: 1.25$ ), while in duck the lateral group is relatively scarce in comparison with the medial (the relation of the number of lateral cells to that of the medial being about $1: 2.5$ ).

\section{The mesencephalic root of $V$ in the dove}

The position of the nucleus of the mesencephalic root of $\mathrm{V}$ in the optic tectum and in the roof of the aqueduct, on the main, corresponds in the dove to that described for the chicken and the duck. The cells of the optic tectum (the lateral group) begin about $2 \mathrm{~mm}$. caudal to the frontal pole of the tectum, i.e., about $0.7 \mathrm{~mm}$. frontal to the beginning of the main oculomotor nuclei and about $0.25 \mathrm{~mm}$. caudal to the commencement of the posterior commissure. Thus, they appear in cross-sections approximately at the same time as the ventricular cavity of the optic lobes. The position of the lateral cells of the dove corresponds to that of these cells in the chicken and duck. Some differences exist between the dove and the duck, however, in respect to the mediolateral (or dorsoventral) extension of the lateral group. Thus, in duck the lateral cells are situated throughout the whole dorsolateral wall of the optic ventricle, in the dove they are seen mostly in the medial part of the tectal wall; no cells of the nucleus of the mesencephalic root of $\mathrm{V}$ have been found in dove in the lateral half of the tectum (figs. 13 and 16). In the dove, as in the duck, the lateral group extends as far medialward as do the small nerve cells of the fifteenth layer of the tectum (fig. 13), being very often continuous with the medial group. The differentiation of the lateral cells from the medial ones is here made possible by the difference in shape of the two kinds of cells; as well as by the difference in their situation, for the lateral cells lie among the tectal cells, while the medial ones lie either among the fibers of the commissures between the tectal regions or in the periventricular 
gray about the ventricle. The lateral cells are few in number in each section and usually far apart (fig. 13). They are more numerous and lie relatively nearer to each other in the medial part of the lateral nucleus, close to the medial cells.

The medial cells begin in the adult dove nearly at the same level as the lateral ones (fig. 16). They are relatively numerous at the beginning of the medial group and in sections

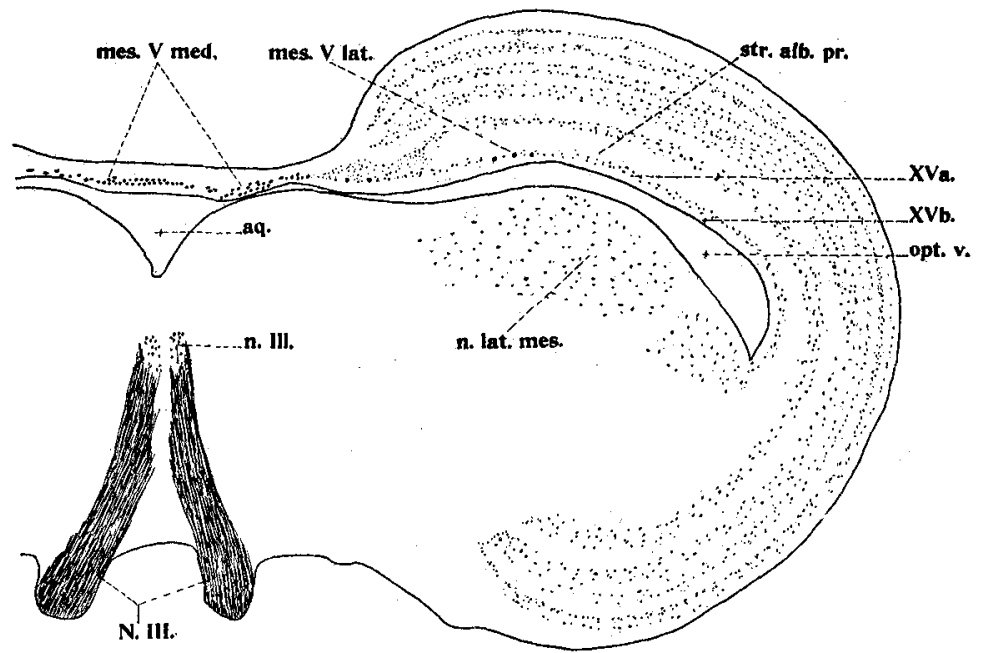

Fig. 13 Cross-section through the midbrain of dove at the level of exit of the oculomotor nerve. Toluidin-blue preparation. $\times 10$. aq., aqueduct; mes.Flat., lateral cells of the meseneephalic root of V; mes.Vmed., medial cells of the meseneephalic root of $V_{;}$n.III., oculomotor nucleus; N.III., oeulomotor nerve; n.lat.mes., nucleus lateralis mesencephali; opt.v., optic ventricle; str.alb.pr., stratum album profundum; $X V a$., cells of the fifteenth layer of Cajal; $X V b$., fibers of the fifteenth layer of Cajal.

passing through the frontal end of the oculomotor nucleus; forty-five to ninety cells are found in a cross-section, as evidenced by serial counts. However, quite soon (about 0.8 $\mathrm{mm}$. from the frontal limit of the nucleus of the mesencephalic root of $\mathrm{V}$ ) the medial cells become less dense, though they extend caudad to the level of the trochlear nucleus and disappear only at the beginning of the decussation of this nerve, 
being situated in their caudal portion in the anterior medullary velum.

The lateral cells disappear nearly at the level of the caudal end of the oculomotor nucleus, relatively few cells being found caudal to this latter cell mass. The medial cell group extends to the caudal end of the trochlear nucleus. The whole longitudinal extension of the medial group is thus about $2.2 \mathrm{~mm}$, that of the lateral about $1.6 \mathrm{~mm}$., the medial group extending the more caudal of the two (fig. 16). The medial cells are about three times more numerous than the lateral ones, the medial group being thus much more massive than the lateral (fig. 16). The chief mass of the medial nucleus lies at the level of the frontal end of the oculomotor nucleus and close in front of it. The cells of the lateral group decrease caudally, and here the nuclear mass does not lie so near to the medial cells as it does in its frontal part (fig. 16). It is located chiefly laterodorsal to the optic ventricle.

In the lateral group the cells are oval (fig. 35, d.), while the medial cells are more elongated. The difference between the average longer and shorter axes in the lateral cells is about $7.6 \mu$, this difference in the medial cells is about $13.5 \mu$. The medial cells are also smaller and less constant in size than the lateral ones, the average diameter of the lateral cells being $28.7 \mu$ (average shorter axis, $24.9 \mu$; average longer axis, $32.5 \mu$ ), that of the medial cells, $22.3 \mu$ (average shorter axis, $15.5 \mu$; average longer axis, $29.0 \mu$ ). The medial cells are larger in the frontal portion of the nucleus than in the caudal part. In some sections through the frontal part of the nucleus, the medial cells surpass in size the largest of the lateral cells. The tigroid substance is more highly differentiated in the lateral cells than it is in the medial ones. Among the medial group, cells of quadrangular and polygonal shapes are much more frequent than they are among the lateral group.

In the lateral part of the medial group, in the region of transition from the aqueduct to the optic ventricle, the predominating cells are elongated in shape and have two proc- 
esses (fig. 35, e.). The one process of these cells is directed medialward, the other lateralward. These cells may be considered as the homologue of the so-called intermediate group, as it was present in the alligator. However, in dove they are even less clearly separable from the medial cells than in the duck, being often found in the former bird quite close to the median line and intermingled with polygonal and ovoid cells. They lie either among the fibers of the posterior commissure or in the periventricular gray around the ventricle. An indication of such an intermediate group is therefore given only by the special aspect of the cells and not by any strict topographical limitations.

In those young doves of one, eight, and ten days studied by us the situation of the nucleus of the mesencephalic root of $\mathrm{V}$ is nearly the same as that described for the adult dove. In the one-day dove the lateral and medial cells are already well differentiated, the medial cells being more darkly stained and of a more angular shape in toluidin-blue preparations than the lateral. The number of the cells of the mesencephalic root of $\mathrm{V}$, as well as the relation between the number of lateral and the number of medial cells, is nearly the same in the young dove as it is in the adult.

In Cajal preparations the medial cells are not as deeply impregnated as the lateral ones. In most of the lateral cells (fig. $35, d$.) there can be seen but one process, which extends for a short distance dorsalward toward the periphery of the tectum; however, it is traceable only to the deep medullary layer. In some cells the process is seen to divide into two branches, both of which run to the deep medullary layer, the one turned medialward, the other lateralward (as seen in cross-sections). Sometimes the one branch is turned frontalward and the other caudalward (as seen in sagittal sections). In one case (a cross-section) the process could be observed to run lateralward for a short distance in the deep medullary layer and then, turning dorsalward and medialward, to end outside of the deep medullary layer in the thirteenth layer of Cajal. It divides in this layer into three short branches, which 
latter divide again into two or three short and thinner branches. In a few lateral cells two processes are present: the thick one usually, but not invariably, is directed medialward, the thin one lateralward. Sometimes a thick process is seen to run toward the ventricular cavity, being traceable, however, not farther than the cell row of the fifteenth layer of Cajal. The thin process is then directed toward the periphery of the tectum. In some cases a single process is seen to run for a short distance toward the ventricular cavity and then to divide into a short thin process and another short thicker one, which is approximately of the same size as the main process. In a few lateral cells more than two processes are observed. All these processes originate often from the same pole of the cell body; they are short and thick and are directed toward the periphery of the tectum, but are not traceable out of the fifteenth layer of Cajal. In the dove it is possible to see that the thicker process enters the bundles formed by the root fibers of the mesencephalic root of $\mathrm{V}$.

The smaller cells of the caudal portion of the medial group, as well as those few cells that are situated more laterally (between the medial and lateral cells, the 'intermediate' group (fig. $35, e$.$) ), are better impregnated than the larger medial$ cells in the frontal portion of the group. The small caudal cells are often provided, as can be seen in sagittal sections, with two processes, originating from two opposite poles of the elongated cell body. The one process is turned caudalward, the other frontalward. The two processes of the 'intermediate' cells (fig. 35, e.) arise also from the two opposite poles of the cells, the one being here directed medialward and the other lateralward. One of these two processes is usually slender, the other is thick. It is sometimes the thicker process which is turned medialward; again, the more slender has that direction. It would seem probable that the medialward-running process passes to the other side by way of the tectal commissure. However, if there be any crossed fibers, their number cannot be great, since the main fiber masses seem to be uncrossed. Of the two processes of the 
caudomedial cells, the one running caudalward is usually coarser than the one directed frontalward. Both processes are quite short. The larger polygonal and oval medial cells are more faintly impregnated and their processes are not so easily distinguishable. A slender process, sometimes two processes-one slender and one coarse-can be seen in the cross-sections. In sagittal sections the cells often appear to be provided with two or more very slender and short processes, emanating from opposite poles of the cell body.

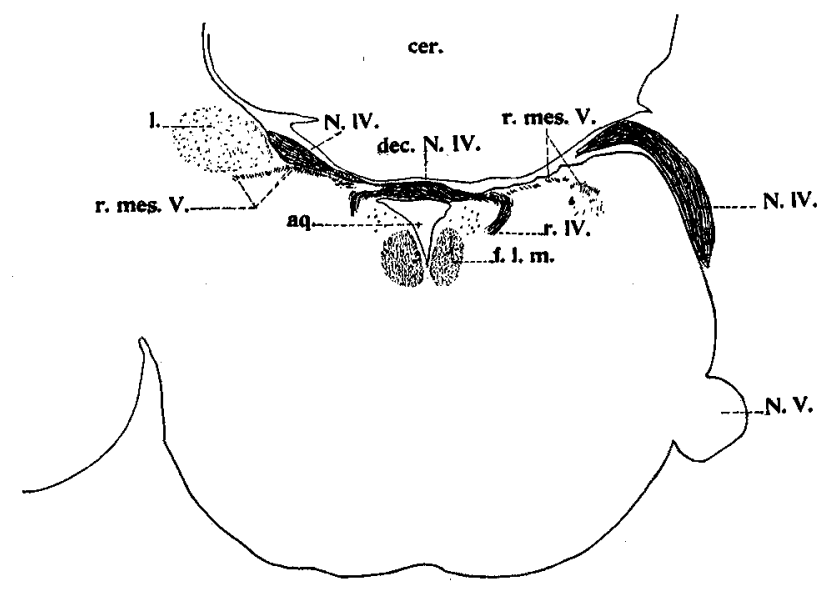

Fig. 14 Cross-section through the region of the trochlear decussation of dove. The section is farther caudal on the right side of the figure than on the left. Chrom-silver preparation. $\times 10 . a q$. ., aqueduct; cer., cerebellum; $d e c . N$. $I V$., decussation of the trochlear nerves; f.l.m., faseiculus longitudinalis medialis; $l$., laminated gray mass at the level of the trochlear decussation; N.IV., trochlear nerve; N.V., trigeminal nerve; r.IV., trochleax root; r.mes.V., mesencephalic root of $V$.

The fibers of the cells of the mesencephalic root of $\mathrm{V}$ leave the nucleus in several bundles. In the median line and close to it, some fibers derived probably from the medial cells are seen to descend (in the sagittal series) sharply caudalward, being situated ventral to the tectal commissure, between the latter and the roof of the aqueduct. They continue caudalward in the anterior medullary velum to the level of the trochlear decussation. Here, they turn lateralward and so 
lie just in front of the trochlear root. Another small bundle of the root fibers of the mesencephalic root of $V$ makes a turn lateralward approximately halfway distant between the caudal end of the tectal commissure and the trochlear decussation, and still another bundle turns lateralward closely caudal to the tectal commissure. The more medially situated fibers, before their lateral turn, run in a longitudinal direction for a greater distance than do the lateral ones. Having made this turn lateralward in the anterior medullary velum, all these fiber bundles run farther in a longitudinal direction, being situated lateral to the trochlear root.

It would seem that some of the fibers running in the anterior medullary velum enter the trochlear crossing and so join the trochlear nerve. However, a certain proof for it cannot be given in normal preparations, since the possibility cannot be entirely eliminated that these fibers of the mesencephalic root of $\mathrm{V}$ may still detach themselves from the trochlear fibers in their further course. Having passed the region of the trochlear root, some of the fibers of the mesencephalic root of $\mathrm{V}$ descend to the decussatio veli, run for a short distance caudalward, ventral to the fibers of the decussatio veli, and then turn again lateralward. Other fibers turn lateralward before reaching the decussatio veli at the level of the trochlear root. The fibers situated in the ventral part of the decussatio veli run in a lateral direction for a distance of about $0.36 \mathrm{~mm}$, after which they make an acute turn ventralward toward the motor nucleus of $V$. They are joined here by the more laterally lying fibers, which descend along the anterior medullary velum, and also by the fibers turning lateralward at the level of the trochlear root. All these fibers are spread out in the region of the motor nucleus of $\mathrm{V}$ and cannot be followed farther in our preparations.

The fibers of the lateral nucleus (fig. 15) collect also in several small bundles, which in cross-sections are easily distinguishable from other tectal fibers at the level of transition of the aqueduct into the optic ventricle. The small bundles are situated in the inner part of the deep medullary layer 
in the medial half of the optic tectum. The root fibers of the mesencephalic root of $V$, coarser than other fibers, at first are directed medialward for a short distance and then slightly ventralward. Soon, however, they turn caudalward. The most medial of these bundles are joined by fibers which come from the frontal portion of the medial nucleus. Such fibers run at first lateralward and then, after having reached the region of the medial part of the tectum at the plane of transition between the aqueduct and optic ventricle, pass caudalward to descend in company with the fibers from the

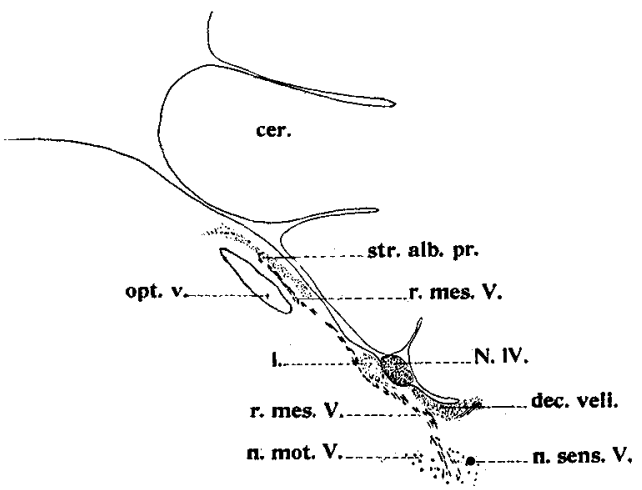

Fig. 15 Sagittal section through the midbrain and pons of dove at a level lateral to the aqueduct and to the fourth ventricle. Chrom-silver preparation. $\times 10$. cer., cerebellum; dec.veli., decussatio veli; $l$., laminated gray mass at the level of the trochlear decussation; N.IV., trochlear nerve; n.mot.V., motor nucleus of $\mathrm{V}$; n.sens.V., sensory nucleus of $\mathrm{V}$; opt.v., optic ventricle; r.mes.V., mesencephalic root of $\mathrm{V}$; str.abb.pr., stratum album profundum.

lateral group. In regions caudal to the communication of the aqueduct with the optic ventricle, several fiber bundles can also be seen coming from the deep medullary layer of the tectum (fig. 15). They lie ventral to the tectal commissure and run medialward and slightly ventralward toward the periventricular gray of the ventricle. At some levels of the cross-sections the root fibers of the mesencephalic root of $\mathrm{V}$ are seen in the roof of the aqueduct among the fibers of the tectal commissure. These root fibers of the mesencephalic root of $\mathrm{V}$ have, for a very short distance, a dorsoventral 
course; the more lateral of these fibers have a mediolateral course. The fiber bundle emanating from cells of the root of $\mathrm{V}$ is thus composed of several bundles and, throughout the whole region between the optic ventricle and the aqueduct, it is situated inside the deep medullary layer and also in the roof of the aqueduct among the fibers of the posterior commissure and, more caudad, ventral to the fibers of the tectal commissure. The root fibers of the mesencephalic root of $\mathrm{V}$ are easily distinguishable from all other fibers of this region because of their typical appearance, especially their coarseness and staining reaction.

A little more caudalward, the laterally lying bundles are situated dorsomedial and then caudal to the lateral mesen-

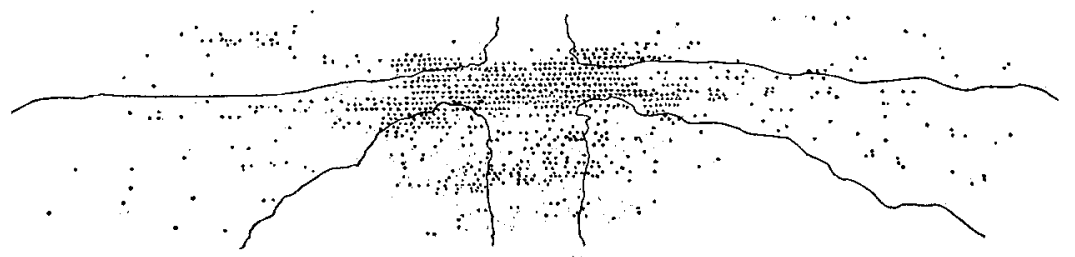

Fig. 16 Graphic reconstruction of the nucleus of the mesencephalic root of $\mathrm{V}$ of dove. The cells of the meseneephalic root of $\mathrm{V}$ and the outlines of the ventricles are projected on a horizontal plane. $\times 10$. The line indicates the outline of the ventricles. The dots represent the cells of the mesencephalic root of $\mathrm{V}$. The outline of the tectum is not indicated.

cephalic nucleus; the more medial fibers are ventral to the tectal commissure in the periventricular gray of the ventricle. Here, all these fibers are directed ventralward and medialward. Still more caudalward, the bundles lie closer and closer to each other. At the level of the trochlear decussation the mesencephalic root of $V$ lies lateral to the trochlear root and partly medial, partly ventral, to a laminated gray mass (fig. 14, l.), the description of which is not found in the literature. Here, the root in cross-sections has a curved outline with its concavity directed ventromedialward toward the dorsolateral angle of the aqueduct (fig. 14). The medial fibers, lying in the anterior medullary velum, run in a longitudinal direction at levels frontal to the trochlear decussa tion. They turn into a transverse direction just in front of 
this decussation, as has been described above. Caudal to the trochlear decussation, the fibers of the mesencephalic root of $\mathrm{V}$ turn ventralward and slightly lateralward to scatter out in the region of the motor nucleus of $\mathrm{V}$. They lie partly between the sensory and motor nucleus of $V$ (fig. 15). According to the observations of Wallenberg ('04), made by means of the degeneration method, some fibers of the mesencephalic root of $V$ of the dove should enter the cerebellum in order to end in the medial cerebellar nucleus. We cannot deny the possibility of some few fibers of the root or their collaterals taking such a course, since some of them run very close to the fibers of the cerebellar peduncle. Our dove preparations, however, do not show such a connection, since most of these fibers, at least, seem after a short course in the ventral part of the decussatio veli to turn lateralward and ventralward into the region of the motor nucleus of $V$. Neither is it possible to observe the fibers of the mesencephalic root of $V$ running caudalward from the region of the motor nucleus of $\mathrm{V}$, as was described by Probst ('99) for mammals and by Wallenberg ('04) for birds.

\section{The mesencephalic root of $V$ in the English sparrow}

In the English sparrow, as in all other birds studied by us, the cells of the nucleus of the mesencephalic root of $V$ are differentiated into a lateral and a medial group, but in the sparrow the lateral cells are relatively more numerous than in duck and dove, in fact, almost equal in number to the medial cells as evidenced by serial-cell count (table 1 ). In this respect the relations resemble those found in the chicken, while in the duck and dove the lateral group is less developed than the medial one. In the sparrow, as in the duck, single lateral cells are seen frontal to the medial ones, while in the dove both types of cells begin nearly at the same level. Unlike those in the duck, the lateral cells in the sparrow extend as far caudal as the medial cells. The mediolateral extension of the lateral group in the sparrow-throughout the whole length of the dorsolateral wall of the optic ventriclecorresponds to the situation of this group in the duck. 
The following measurements based on a cross-section series of sparrow give an idea of the relative extent of the nuclei. Some single lateral cells are found in the sparrow about $0.4 \mathrm{~mm}$. frontal to the posterior commissure. They begin to increase in number at the place where the posterior commissure appears in cross-sections. They are most numerous in sections passing just in front and through the frontal part of the oculomotor nucleus (the frontal limit of the latter being about $0.4 \mathrm{~mm}$. caudal to the beginning of the posterior commissure) and remain so for a distance of about $0.5 \mathrm{~mm}$. (about fifteen to twenty cells in each section, as determined by cell count). They disappear entirely at a level about $0.2 \mathrm{~mm}$. in front of the trochlear decussation. The lateral cells are situated in the dorsolateral wall of the optic ventricle. However, some few cells can be found ventromedial to this ventricle, amid the cells of the dorsal part of the lateral mesencephalic nucleus.

The frontal limit of the medial cells corresponds to that of the posterior commissure, i.e., about $0.4 \mathrm{~mm}$. frontal to the oculomotor nucleus. These medial cells lie first in the posterior commissure and begin to increase rapidly here until they reach a relatively great number. They decrease again after the disappearance of the posterior commissure. Caudal to the posterior commissure, the medial cells are situated ventral to the tectal commissure and still farther backward in the anterior medullary velum, where they extend as far caudalward as the lateral cells.

As seen in horizontal sections, the medial cells are located more dorsally than the lateral ones. They appear in horizontal sections in the roof of the aqueduct about $0.25 \mathrm{~mm}$. below the upper surface of the tectum opticum or $0.65 \mathrm{~mm}$. dorsal to the aqueduct. At this level only three cells are seen on either side near the median line. Farther ventralward the medial cells become more and more numerous. The group extends in a lateral direction toward the optic tectum so that, when the lateral cells make their appearance-at a level about $0.16 \mathrm{~mm}$. ventral to that of the medial cells in the 
horizontal sections-both groups are occasionally continuous with each other. The medial cells are still more numerous than the lateral at each horizontal level. They are arranged, in these sections, in a single, slightly curved line, the concavity of the line being directed caudalward (fig. 17). The greatest number of cells of the medial group is found in the horizontal series in sections between the ventral border of the tectal commissure and a plane about $0.35 \mathrm{~mm}$. above that

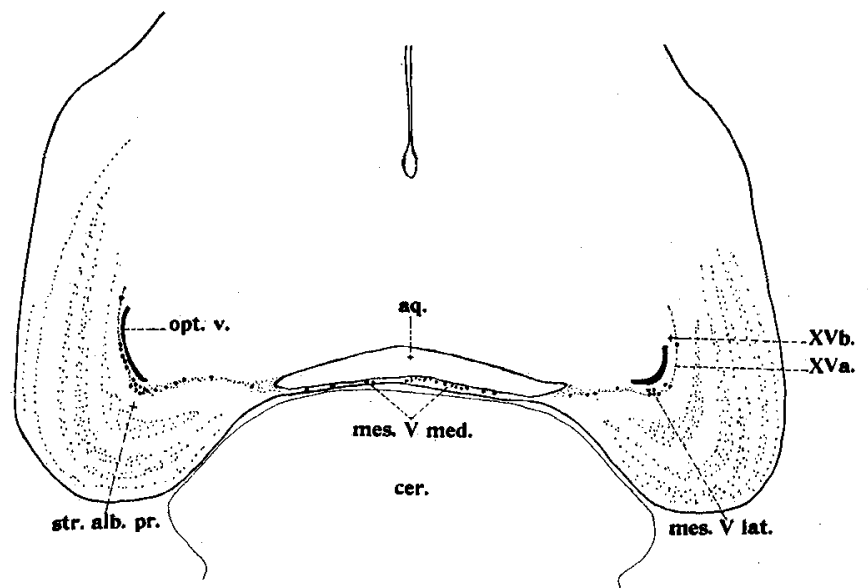

Fig. 17 Horizontal section through the optic tectum of the English sparrow. Toluidin-blue preparation. $\times 10$. aq., aqueduct; cer., cerebellum; mes.Vlat., lateral cells of the mesencephalic root of $\mathrm{V}$; mes.Vmed., medial cells of the mesencephalic root of $\mathrm{V}$; opt.v., optic ventriele; str.alb.pr., stratum album profundum; $X V a$., cells of the fifteenth layer of Cajal; $X V b$., fibers of the fifteenth layer of Cajal.

border. In horizontal sections passing ventral to the tectal commissure the medial cells lie in the anterior medullary velum and gradually decrease in number. Some few cells are found also close to the ependymal layer of the roof of the aqueduct. The lateral extension of the medial group is largest in sections passing at a level about 0.2 to $0.25 \mathrm{~mm}$. above the ventral border of the tectal commissure. Dorsalward and ventralward from this level the lateral extension of the medial group decreases, so that in sections passing 
either through the ventral part or through the dorsal part of the group, the cells are found chiefly close to the median line, only a few cells being situated more laterally. The medial cells are situated mostly very near to one another. In horizontal sections their shape is usually a polygonal or a quadrangular one; cells with an oval outline are less frequent.

The lateral group appears in horizontal sections a little (about $0.16 \mathrm{~mm}$.) more ventral than the medial group. The lateral cells lie in front of the dorsal part of the posterior commissure. They are arranged in a curved line that is situated dorsal, caudal, and lateral to the optic ventricle (fig. 17). The concavity of the line is directed frontalward and medialward. The most dorsal cells are found in levels passing about $0.4 \mathrm{~mm}$. above the ventricular cavity. In horizontal sections these cells are arranged in a single laver, forming a continuous line. Caudal to the optic ventricle the lateral cells are more numerous. The cell line is here not so regular, the cells being collected into small groups. This is especially the case in the region where the optic ventricle makes a curve in turning frontalward. Lateral to the optic ventricle the cells of the nucleus of the mesencephalic root of $V$ extend rostralward until the frontal pole of the ventricle. In sections passing ventral to the level of the ventral border of the tectal commissure the lateral cells are less numerous. Ventral to the upper surface of the spiriform nucleus only single cells are found lateral to the optic ventricle.

In the lateral group the predominant type of cells is one having a more rounded outline. Medial to the lateral group, between the latter and the medial group, cells of a somewhat fusiform shape are often seen. These cells are either intermingled with the lateral or with the medial cells and the separation of these cells into a special ('intermediate') group is therefore, as in other birds, very difficult. The number of these cells is not great. Those round cells of the lateral group which have the most regular outline are found in the 
horizontal series in sections passing from $1 \mathrm{~mm}$. to $1.4 \mathrm{~mm}$. below the upper surface of the tectum, i.e., at levels where the lateral group has its greatest extent and the medial group is beginning to decrease.

As has been already mentioned, the medial cells are mainly of a polygonal shape. This polygonal outline is shown best in sections from $0.4 \mathrm{~mm}$. to $0.65 \mathrm{~mm}$. below the upper surface of the tectum, where the medial group is most numerous. The most dorsal of the medial cells (they are also the most frontal) approach the lateral cells in form and size. The medial cells are usually deeply stained in toluidin-blue preparations. It is very difficult to distinguish in them the welldifferentiated tigroid granulations, which are, in general, very clear in the lateral cells. In sagittal sections the oval medial cells are often oriented with their long axis in a frontocaudal direction. They are provided with two processes, the one of which is turned caudalward, the other frontalward. Such cells are mainly found near the median line, between the ventral and dorsal part of the posterior commissure. Cells with more than two processes are very rare among the medial cells; none of them is observed among the lateral ones. In sagittal sections the latter cells are sometimes seen to have a single, quite thick, well-stained process directed toward the deep medullary layer. The size of the lateral cells is about $22 \mu$ on the average, that of the medial about $17 \mu$. The difference between the longest and shortest diameter of the cells is much greater for the medial cells (table 2). This is especially well seen in sagittal sections, since the shortest axis of the cells is the dorsoventral one.

In chrom-silver preparations the medial cells are so faintly impregnated that no processes can be seen in them. The lateral cells are well impregnated. In some cells the intracellular fibrillar network is clearly seen. The fibrils are dark, almost black, and thin at the periphery of the cell body; they are not so heavily impregnated but are thicker in the central part of it. The cell nucleus is paler than the protoplasm. In 
many cells a quite large process can be seen. In none of them is it possible to observe with certainty more than one process. The single processes of the cells of the mesencephalic root of $V$ turn caudalward and slightly medialward in the deep medullary layer of the tectum, lying at the inner border of this layer. Having reached the caudal pole of the optic ventricle, the fibers turn more medialward-some of them slightly ventralward-and form several small fiber bundles (as seen in horizontal sections). At the same time they swing slightly frontalward in order to lie in front of the tectobulbar fibers. Having passed this latter tract, the root fibers of the mesencephalic root of $\mathrm{V}$ turn again slightly caudalward. They lie in front of and ventral to the tectal commissure. Thus the fiber bundles of the mesencephalic root of $\mathrm{V}$ follow, in horizontal sections, a slightly curved line, which passes around the optic ventricle (fig. 18). The concavity of this curved line is directed frontalward. A second curve, in the line which is observable in the horizontal section, has its concavity caudalward (fig. 18). This second curve is due to the frontal course of the fibers with reference to the bulbar tract, so that they lie between the latter and the lateral mesencephalic nucleus. The bulbar tract lies caudal and the lateral mesencephalic nucleus frontal to the root fibers of the mesencephalic root of $V$. The fibers run thus medialward and ventralward toward the dorsolateral angle of the aqueduct. Having arrived there, they turn caudalward at the side of the anterior medullary velum. During their whole descent along the anterior medullary velum the lateral fibers are joined by the medial ones, which latter run for a distance in the velum in longitudinal direction and then turn lateralward. The root fibers of the mesencephalic root of $V$ increase in bulk until the beginning of the trochlear decussation, at which level the mesencephalic root of $\mathrm{V}$ is completely formed. It lies now lateral to the trochlear root and ventral to the crossed part of the trochlear nerve. Farther caudalward, in the region of the pons, the mesencephalic root of $V$ lies lateralward to the periventricular gray of the IVth ventricle, 
and, having reached the level of the motor nucleus of $V$, the mesencephalic root of $\mathrm{V}$ turns ventralward and medialward. It lies then caudal and lateral to the motor root of $V$, between the latter and the sensory root of $V$. The fibers of the mesencephalic root of $\mathrm{V}$ apparently intermingle with the motor root of $V$, though some of them possibly may join the sensory root. However, such a union cannot be observed with certainty in our preparations.

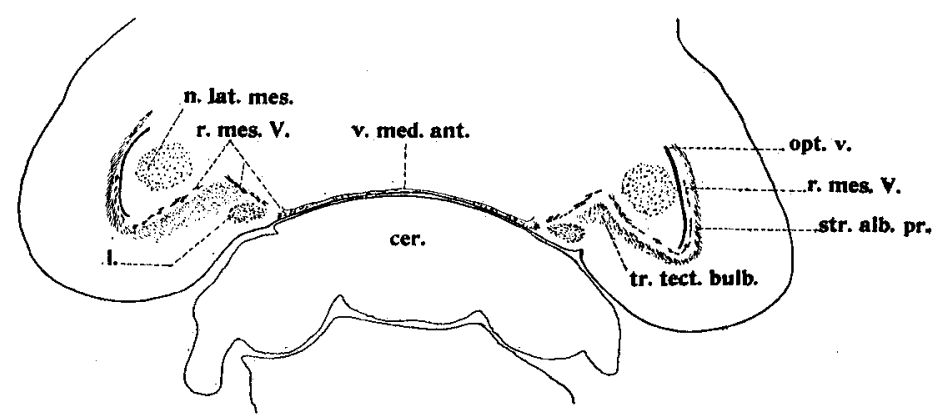

Fig. 18 Horizontal section through the optic tectum of the English sparrow. Chrom-silver preparation. $\times 10$. cer., cerebellum; l, laminated gray mass at the level of the trochlear decussation; n.lat.mes., nuelens lateralis mesencephali; opt.v., optic ventricle; r.mes.V., mesencephalic root of $\mathrm{V}$; str.alb.pr., stratum album profundum; tr.tect.bulb., tractus tectobulbaris; v.med.ant., velum medullare anterius.

\section{THE MESENCEPHALIC ROOT OF V IN MAMMALS}

In higher mammals the nucleus of the mesencephalic root of $\mathrm{V}$ extends from the region of the corpora quadrigemina anteriora (or tectum) into the region of the pons-thus more caudalward than in submammalian forms. The relations in Marsupialia, and especially in Monotremata, remind us, however, of those in submammals (van Valkenburg, '11). The structure of the midbrain has undergone in mammals considerable modification. In the adult forms studied by us the aqueduct is, in general, relatively narrow and does not present a large recess, as is the case for the optic ventricle in submammals. However, in certain embryonic forms the lateral recess of the aqueduct attains quite noticeable dimen- 
sions. In adult mammals the cells of the mesencephalic root of $V$ lie then chiefly lateral to the aqueduct. In rabbit embryos of $3 \mathrm{~cm}$., where the lateral recess of the aqueduct is relatively large, the cells lie dorsal, lateral, and ventral to this recess in a position similar to that of the lateral group of cells of the mesencephalic root of $\mathrm{V}$ in certain submammals. In mammals, as in birds, those cells of the mesencephalic root of $\mathrm{V}$ which lie in the region of the corpora quadrigemina anteriora are situated close to the inner border of the stratum album profundum. However, in mammals they are usually farther removed from the ventricular cavity. This is due to the fact that the periventricular gray, which lies between the stratum album profundum and the ependyma and which was, considered by Cajal ('09) as the homologue of the fifteenth layer in birds, is in mammals quite extensive. In the region of the fourth ventricle the cells of the mesencephalic root of $\mathrm{V}$ of mammals sometimes are bordered on their inner side by the cells of the nucleus loci coerulei, which in these forms lies between the periventricular gray and the cells of the mesencephalic root of V. Cells in a medial position similar to that of the medial cells in reptiles and birds, are in higher mammals relatively very rare and in some forms not present at all.

The mesencephalic root of $V$ in the rabbit

A detailed description of the nucleus of the mesencephalic root of $\mathrm{V}$ as observed in the rabbit has been given by Willems in his work on the trigeminus of this animal ('11). According to this author, the nucleus extends very far frontalward at early stages of development, a few cells of the nucleus having been observed by him in an embryo of $22 \mathrm{~mm}$. even in the region of the thalamus opticus. The frontal limit of the nucleus of the mesencephalic root of $\mathrm{V}$ is found in the adult animal in the region of the inferior part of the corpora quadrigemina anteriora, while its caudal limit corresponds in the adult, as in the embryo, to the level of the motor nucleus of $\mathrm{V}$. 
Our observations on the nucleus of the mesencephalic root of $V$ as pertains to the rabbit are based on studies of several sagittal series of chrom-silver preparations of embryos and young animals. In two series of embryos of $3 \mathrm{~cm}$. crownbreech length, the frontal limit of the nucleus of the mesencephalic root of $\mathrm{V}$ is observed in the region of the posterior commissure, no cells having been found frontal to this level. It is possible that the few cells seen by Willems in the region of the thalamus opticus in an embryo of $22 \mathrm{~mm}$. are not impregnated in our silver material.

In the embryo of $3 \mathrm{~cm}$. length the aqueduct has a relatively large recess, extending lateralward into the corpora quadrigemina and corresponding to the optic ventricle of lower forms. In sagittal sections passing through the most medial part of the nucleus of the mesencephalie root of $\mathrm{V}$, the cells of the nucleus are scattered in the periventricular gray frontal, dorsal, and ventral to the recess of the aqueduct. They are bordered on the outside by the stratum album profundum. No cells are found in sections passing through the median line or close to it. A clustering into small groups of two or three cells is already evident. The root fibers usually lie lateral to the cells. In addition to these cells in the region of the corpora quadrigemina anteriora, a few cells are seen in the region of the corpora quadrigemina posteriora and in the anterior medullary velum. In the former the cells lie ventral to the recess of the aqueduct and in a nearly vertical row, which turns, forming a genu, caudalward into the anterior medullary velum. The angle of the genu is open dorsalward. The cells in the anterior medullary velum lie ventral to the trochlear decussation and to the decussatio veli. In sections passing through levels slightly more lateralward another row of cells of the nucleus of the mesencephalic root of $\mathrm{V}$ appears in addition to the above-described cells. This second row lies more ventrally and caudally, and is seen at this level ventral to the IVth ventricle and dorsal to the major fiber bundles of the region. The cell row extends in a longitudinal direction from the region of the caudal part 
of the corpora quadrigemina anteriora into the region of the pons, but it has not yet reached the level of the motor nucleus of $V$. The fibers of the mesencephalic root of $V$ usually lie ventral to the cells. Farther lateralward, the cavity of the IVth ventricle disappears in the region of the anterior medullary velum. The dorsal and the ventral rows approach each other more and more and at last fuse together in their middle portions (fig. 19). The shape of the caudal portion of the nucleus of the mesencephalic root of $V$ at this level resembles somewhat the letter $\mathrm{X}$, the frontodorsal extremity of which is located in the region of the corpora quadrigemina posteriora, the caudodorsal is directed toward the cerebellum, while the caudoventral, the longest one, follows the course of the root toward the motor nucleus of $V$ (fig. 19). The frontoventral portion is less pronounced and contains the smallest number of cells. It continues into the cell row which is situated ventral to the lateral recess of the aqueduct, in the region of the corpora quadrigemina anteriora. The trochlear root passes medial to the frontal portion of the dorsal row, a few cells of this dorsal line being situated among the fibers of this root. The place of junction of the dorsal and ventral row of cells of the nucleus of the mesencephalic root of $V$ corresponds approximately to the level of the brachium conjunctivum. In more lateral sections the cells disappear just in the region of the brachium conjunctivum; the cells are most numerous then at levels caudal to the brachium conjunctivum and the nucleus consists here of two portions joined together at a sharp angle. The one portion is directed dorsocaudalward toward the cerebellum, the other ventrocaudalward toward the motor nucleus of $V$. The cells in the regions of the corpora quadrigemina anteriora are not numerous; they lie dorsal, frontal, and ventral to the lateral recess of the aqueduct. An arrangement into a regular line with longitudinal direction is evident in the ventral part of the nucleus, while the dorsal cells are more scattered. The line lies at the outer border of the periventricular gray. It is sometimes continuous with the above- 
described frontoventral portion of the $\mathrm{X}$-shaped caudal masses of the nucleus of the mesencephalic root of $\mathrm{V}$.

In sagittal sections passing through the level of exit of the motor root of $\mathrm{V}$ the nucleus of the meseneephalic root of $\mathrm{V}$ is composed of two cell groups: a frontal, lying in

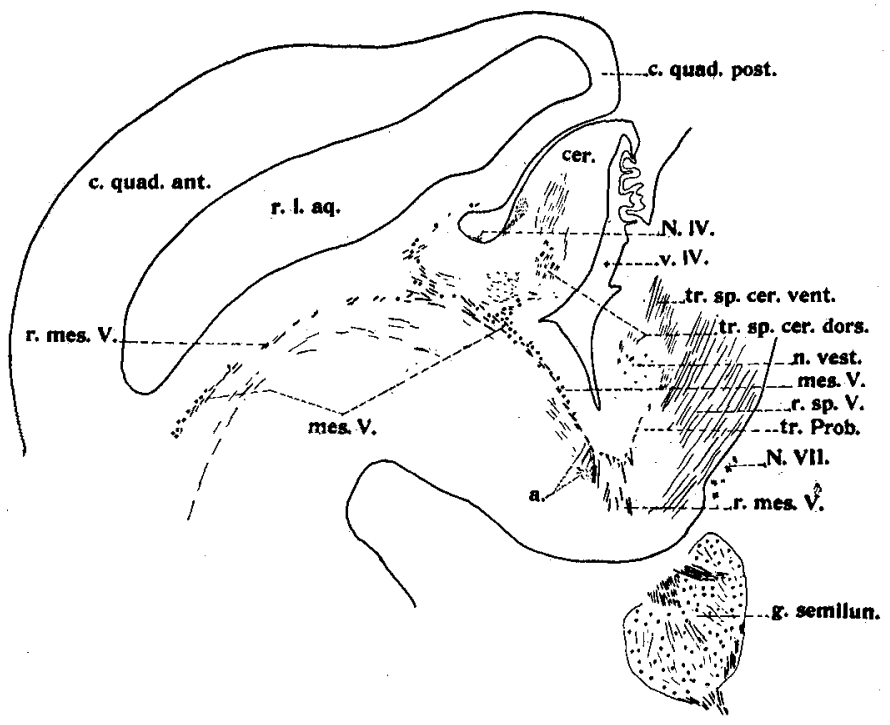

Fig. 19 Sagittal section of the tectum and pons of a rabbit embryo of $3 \mathrm{~cm}$. The seetion passes lateral to the aqueduct. Chrom-silver preparation. $\times 20$. $a$., fine branches from the fibers of the mesencephalic root of $V$ to the motor nucleus of $\mathrm{V}$; cer., cerebellum; c.quad.ant., corpus quadrigeminum anterius; c.quad.post., corpus quadrigeminum posterius; g.semilun., ganglion semilunare; mes.V., cells of the meseneephalie root of $\mathrm{V} ; N . I V$., trochlear nerve; $N . V I I$, , seventhi nerve; n.vest., nucleus nervus vestibularis; r.l.aq., lateral recess of the aqueduct; r.mes.V., mesencephalic root of V; r.sp.V., spinal root of $\mathrm{V}$; tr.Prob., caudalward-running fiber bundle of the mesencephalic root of $\mathrm{V}$ (tractus Probsti) ; tr.sp.cer.dors., tractus spinocerebellaris dorsalis; tr.sp.cer.vent., tractus spinocerebellaris ventralis; v.IV., fourth ventricle.

the region of the corpora quadrigemina anteriora and a caudal group, situated caudal to the region of the brachium conjunctivum, in the region of the pons. The pontine portion of the nucleus is richer in cells and more compact. It is larger in its proximal part, becomes gradually narrower farther distalward, and extends as a single row to the level 
of the motor nucleus of $V$. Ventral to the cells lie fibers of the mesencephalic root of $V$ and the formatio reticularis pontis; medial to the nucleus of the mesencephalic root of $\mathrm{V}$, in this region, is located the nucleus loci coerulei (Willems, '11). Dorsal and frontal to the pontine portion of the nucleus lies the brachium conjunctivum, lateral and dorsocaudal, the ventral spinocerebellar tract. The pontine portion of the nucleus of the mesencephalic root of $V$ begins now to decrease lateralward and disappears entirely as soon as the level of exit of the sensory root of $V$ is reached.

In sagittal sections passing through a plane where the lateral recess of the aqueduct is smaller and seen only in the caudal part of the midbrain, the cells of the midbrain portion of the nucleus of the mesencephalic root of $\mathrm{V}$ lie in a curve at the inner border of the stratum album profundum. The concavity of this eurve is directed caudalward, toward the recess. In still slightly more lateral sections the cells of the ventral part of the curve form just in front of the recess a more compact cell mass. The cells in the more frontal and in the dorsal portion of the curve remain scattered.

Lateralward, the cavity of the recess decreases more and more in its proximal part, but the caudal limit is the same as before. The compact cell mass retains its relation to the frontal pole of the recess and lies thus more caudally with reference to the proximal limit of the nucleus. In sections where the fibers of the stratum album profundum begin to appear in a more vertical direction, the nucleus of the mesencephalic root of $\mathrm{V}$ is interrupted by the passing ventralward of the fibers of this stratum. One part of it lies now frontal to these fibers and is composed of scattered cells in the periventricular gray; the other part lies caudal to the fibers and consists of a vertical and a sagittal cell row, which rows come together at a sharp angle, open caudalward toward the recess of the aqueduct. Farther lateralward, the frontal and the caudal portions of the nucleus in this region become more and more separated from each other. The 
caudal lies now in the region of the corpora quadrigemina posteriora and the frontal in that of the corpora quadrigemina anteriora. The last portion becomes smaller and smaller and disappears at last. The caudal portion retains its angular shape as long as the recess of the aqueduct is seen in sagittal sections. After the disappearance of the latter, the angle smooths out and becomes a curved line, with the concavity turned dorsocaudalward. The cells disappear soon in sections lateral to the recess.

The fibers of the mesencephalic root of $\mathrm{V}$, in a position ventral to the cells, course to the region of the motor nucleus of $\mathrm{V}$. The fiber bundle is situated dorsal to the latter and its greater part enters this nucleus in many small bundles joining the motor root of $\mathrm{V}$. A part of the root leaves the brain caudal and lateral to the motor nucleus of $V$, being located between the motor and sensory roots, apparently more intimately associated with the sensory than with the motor division.

The cells of the nucleus of the mesencephalic root of $V$, in the embryo, are of a relatively small size (fig. $35, g$.). In our silver material they appear round or of an irregularly polygonal shape with a smooth surface. Monopolar, as well as multipolar and bipolar, cells occur. The processes of the latter arise either from two opposite or from one pole of the cell body. All processes, except one thick one forming the root, are short and traceable not far from the cell body. Sometimes slender branches are seen to be derived from the root fibers. Some of these branches, arising from the caudal part of the root, are seen to run caudalward (fig. 19). Often the thick process of the cell is directed toward the cerebellum and ean be traced quite far upward into the cerebellum, lying caudal and ventral to the fibers of the ventral spinocerebellar path. Sometimes a slender process arises from the opposite pole of the cell and is directed ventralward.

In one of our chrom-silver series of rabbit embryos of $3 \mathrm{~cm}$. length, the cells of the nucleus of the mesencephalic root of $\mathrm{V}$ can be seen very far down among the root fibers, between 
the sensory and motor roots of $V$. Some of them are found even among the sensory fibers just at their exit. These cells (we could count twenty-four of them on one side) are mostly bipolar, with a process at either end and with the thick process directed outward.

A very few cells lie outside of the brain, between the latter and the semilunar ganglion. They are similar in appearance to the cells of this ganglion; however, their relation to the cells of the mesencephalic root of $\mathrm{V}$ suggests their belonging to the system of the latter.

Allen ('25) has described for the cat round or oval ganglionic cells in the motor root of $\mathrm{V}$. These cells are always unipolar and mostly provided with capsules. He considers these cells as proprioceptive sensory cells of the same character as the cells of the mesencephalic root of $V$. The destruction of these cells, caused by the extirpation of the ganglion semilunare, produces, according to this author, an ascending degeneration in the mesencephalic root of $V$. Ganglionic cells in the portio minor of the $V$ th nerve have been found also by Takeda ('25), who regards them as neurones of the ganglion semilunare, which have migrated into the portio minor. Nerve cells have been observed also in the roots of the IIIrd (Nicholls, '15) and the VIth (Nicholson, '24) nerves, and in the anterior roots of the spinal nerves (Takeda, '25). Nicholson ('24) has seen them even in the IIIrd and VIth nerves in the orbita. The explanation of Allen as to the character of the cells found by him in the motor root of $\mathrm{V}$ seems to us sound. The position of the cells of the mesencephalic root of $\mathrm{V}$ at the point of emergence of the Vth nerve in our preparations of rabbit embryos suggests a migration of the cells of the mesencephalic root of $\mathrm{V}$ from the brain along the course of the root fibers.

In two sagittal series of rabbit foetus a week before birth, the position and arrangement of the cells of the nucleus of the mesencephalic root of $V$ are found essentially the same as given for rabbit embryos of $3 \mathrm{~cm}$. length. The recess of the aqueduct does not extend as far lateralward in the for- 
mer as in the latter. Also, in the former no cells are seen in our material dorsal to the recess. Some cells of the pontine portion of the nucleus enter into a very close relationship to the cerebellum, being seen very far dorsally in the cerebellar peduncles, caudal to the ventral spinocerebellar path. Certain thick processes of these cells are directed at first dorsalward and turn then into other directions. In the foetus of one week before birth the proportion of bipolar (fig. 35, h.) and multipolar cells, as compared with the number of unipolar cells, is smaller than in the embryo of $3 \mathrm{~cm}$. This agrees with the findings of S. Ramón y Cajal ('96).

In young rabbits of one day after birth the cells of the mesencephalic root of $\mathrm{V}$ (fig. $35, i$.), are in general larger than in the embryos and foetuses studied, though quite a large proportion of small cells are still found in the one-day rabbit scattered among the larger ones. The majority of the cells appear to be provided with only one process; bipolar and multipolar cells occur but rarely. The position and extension of the nucleus of the mesencephalic root of $\mathrm{V}$ in the one-day rabbit is the same as in the foetus of one week before birth. The cells in the anterior medullary velum lie in the ventral part of the latter and extend quite close to the cerebellum. Many fibers of the mesencephalic root of $\mathrm{V}$ are seen in the velum. In the more lateral sections the caudal portion of the nucleus, behind the brachium conjunctivum, is more rich in cells than in the embryos above discussed and in certain sagittal sections, the nucleus is noted as a quadrangular nuclear mass, the two caudal ends of which are stretched out, the one extending into the cerebellar peduncles, the other toward the motor nucleus of $\mathrm{V}$ and lying dorsal and partly lateral to this latter. The cells in the midbrain lie lateral to the aqueduct, in a one-day rabbit the recess of the aqueduct being already very small.

A small fiber bundle, consisting probably of collaterals, is seen to arise from the caudal part of the mesencephalic root of $V$ and to run caudalward. According to Probst ('99), not all fibers of the mesencephalic root of $V$ are exhausted at 
the level of exit of the Vth nerve. Some of them run farther caudalward until the level of the glossopharyngeal-vagal nucleus. This author based his statements on studies of Marchi preparations of cat after a lesion of the mesencephalic root of $V$ in the midbrain, especially at the level of exit of the IVth nerve. He located the bundle ventral to the acoustic nucleus, then between the substantia gelatinosa and the genu of the VIIth nerve, and finally ventral to the glossopharyngealvagal nucleus and the fasciculus solitarius. Collaterals of this bundle have been seen by Probst to enter the Deiters' nucleus and the motor and sensory glossopharyngeal nuclei. Lewandowsky ('04) could identify the bundle at the place designated by Probst. He designated it as the tractus Probsti, but derived it from the nucleus spinalis tecti intratrigeminalis of Kohnstamm ('00). However, Kohnstamm and Quensel ('08) have denied the possibility of such an origin of the bundle, as suggested by Lewandowsky, since after a lesion of the tractus Probsti in rabbit no alterations of the nucleus intratrigeminalis cells could be observed, and vice versa. Therefore, these authors considered the tractus Probsti as a bulbar continuation of the mesencephalic root of V. Economo and Karplus ('09) and Wallenberg ('04) arrived at a similar conclusion. The former based their statements on Marchi preparations of eat and monkey prepared after a section of the pes pedunculi, while the latter had seen the tract in Marchi preparations of birds after a lesion of the nucleus of the mesencephalic root of $V$ in the midbrain. However, Wallenberg could not prove direct connections with the nuclei of vagus and glossopharyngeus nerves. According to May and Horsley ('10), the fibers described by Probst and Lewandowsky constitute two different paths, neither of which originates from the roots of $V$. They stated that no fibers arose from the mesencephalic root of $V$ to extend to any nucleus lower than the oral plane of the vestibular nuclei. The observations of these authors were made on material prepared by the Marchi method, after a severing of the mesencephalic root of $\mathrm{V}$ in cat and monkey in the 
region of the posterior colliculus, or just in front of it or just behind it. Thelander ('24), who also studied the Marchi preparations of cat after a lesion of the mesencephalic root of $V$ in the midbrain, found that the root fibers apparently bifureate at the level of the motor nucleus of $\mathrm{V}$ and that some of these branches can be traced to the upper level of the inferior olivary nucleus. The bundle of Probst has been observed also by Willems ('11), in Cajal preparations of rabbit, to take its origin from collateral branches of the mesencephalic root of $V$. As has been already stated, we have been able to identify collaterals emanating from the mesencephalic root of $\mathrm{V}$ in the region of the motor nucleus of $\mathrm{V}$ and running caudalward (to lie ventral to the VIIIth nucleus), but we are unable in our material to follow these fibers farther distalward or to establish thus their farther course and connections.

In a sagittal series of young rabbit of six days, almost all cells of the nucleus of the mesencephalic root of $V$ seem to us to be of unipolar form. The proportion of larger cells is here greater than in the one-day rabbit. This is the case especially in the caudal part of the nucleus. Collaterals are very well seen in this series. They arise from the thick cell processes in all portions of the nucleus. Often, they are seen to divide after a longer or shorter course into two or three branches. The usual course of the main process is a caudal one. However, sometimes the process is directed dorsocaudalward toward the cerebellum. In some cases it runs in this direction for a certain distance, after which it makes a bend in order to turn ventralward (fig. 20). The fiber is usually more or less straight immediately after its emergence from the cell body. However, it becomes more tortuous in its farther course, especially after it bends. It was possible for us to observe slender branches arising from the process (fig. 20, a.). These branches are traceable quite far into the cerebellum. However, their terminations within the cerebellum cannot be definitely established in our preparations. The slender fibers are very tortuous. Apparently 
the close relationship of the cells of the mesencephalic root of $\mathrm{V}$ with the cerebellum and the deviation of the thick processes from their original caudal course is determined by these collaterals. The process runs toward the cerebellum in order to give off these branches, after which it returns to enter the mesencephalic root of $V$. The collaterals arise either
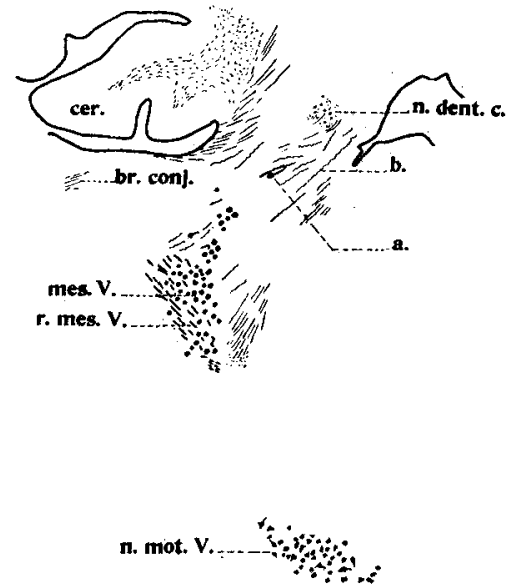

Fig. 20 Sagittal seetion through the caudal portion of the nucleus of the mesencephalie root of $\mathrm{V}$ in a rabbit, six days old. The section passes through the brachium conjunctivum, just medial to the inferior and middle cerebellar peduncles. Chrom-silver preparation. $\times 20$, a., cell of the mesencephalic root of $V$, the thick process of this cell forms a loop which in turn gives off a branch toward the cerebellum; $b$., thin fibers, similar in appearance to the branches from the thick process of the cell $a$. ; br.conj., brachium conjunetivum; cer., cerebellum; mes.V., cells of the mesencephalie root of $V$; n.dent.c., nucleus dentatus cerebelli; n.mot.V., motor nucleus of $\mathrm{V}$; r.mes.V., mesencephalic root of $\mathrm{V}$.

from the ascending portion of the thick fiber or from the place where the fiber makes its bend. A definite proof of the connection of the thick fiber with the cells of the mesencephalic root of $V$ and, at the same time, with the described branches can be given only in a very few cases. However, fibers of the nucleus of the mesencephalic root of $V$ running toward the cerebellum as well as fibers of the same aspect, as the collaterals in question (fig. 20, b.), are relatively 
numerous. A direct connection of the nucleus of the mesencephalic root of $V$ with the cerebellum seems to us, therefore, at least very probable. This connection has also been considered very probable by Willems, though this author could not show it with certainty in his rabbit material. A loop of fibers of the mesencephalic root of $V$ toward the cerebellum is described also by Johnston ('05) in fish. (Scyllium canicula) and the close relation of the root to the cerebellum in amphibians has been noted by many observers (Osborn, '88; Norris, '13, and others). Fibers detached from the mesencephalic root of $\mathrm{V}$ and running toward the cerebellum are quite clear in the silver preparations of our reptile material. The previously referred-to work of Wallenberg ('04), which is concerned with the cerebellar fibers of the mesencephalic root of $V$ in birds, as shown in Marchi preparations, does not entirely eliminate the possibility that other paths to the cerebellum may have been destroyed. The fibers of the mesencephalic root of $\mathrm{V}$ to the cerebellum are quite evident in one of our chrom-silver series of rabbit material and provide thus a relatively certain proof for the existence of such a connection in mammals.

\section{The mesencephalic root of $V$ in the mouse}

The nucleus of the mesencephalic root of $\mathrm{V}$ is situated in the mouse lateral to the aqueduct and to the IVth ventricle. The most frontal cells are found in sagittal sections of chromsilver preparations passing lateral to the aqueduct, through a level where the fibers of the brachium conjunctivum begin to turn medialward, to their crossing. The cells are scattered in the periventricular gray of the aqueduct, caudal to the posterior commissure and ventral to the layer of transverse fibers (the stratum album profundum). The nucleus of the mesencephalic root of $V$ is found in sections near the midline only in the region of the midbrain. Its caudal part is situated more laterally and is, therefore, not seen in sections near the midline. It makes its appearance in sections where the fibers of the trochlear root, as well as those of the 
brachium conjunctivum, are cut more nearly longitudinally. Two separate portions of the nucleus can now be distinguished. The one is located in the caudal part of the corpora quadrigemina anteriora and in the region of the corpora quadrigemina posteriora. The other portion lies caudal to the trochlear root, in the region of the brachium conjunctivum. The frontal portion is formed, as before, of scattered cells lying in the periventricular gray. However, these cells are more concentrated along the ventral and caudal border of the stratum album profundum. Therefore, the shape of this portion of the nucleus is somewhat that of a half-circle, open caudalward. In front of the nucleus the fibers of the decussation of Meynert pass ventralward.

The caudal portion of the nucleus lies at the level of the brachium conjunctivum, and, at its medial part, partly dorsal and partly a little caudal to the latter. The cells are here few in number and situated quite close to the lateral angle of the IVth ventricle.

Farther lateralward, at a level where the trochlear root is seen to leave the brain, the frontal portion of the nucleus of the mesencephalic root of $\mathrm{V}$ lies a little more caudal and more ventral. It still has the same relations and form. The caudal portion of the nucleus has increased quite noticeably. The cells are observed now among the fibers of the trochlear root and those of the edge of the brachium conjunctivum. The latter is situated here more dorsally.

At a level immediately lateral to the exit of the trochlear root, the frontal portion of the nucleus of the mesencephalic root of $\mathrm{V}$ forms a smaller and more nearly complete circle, which is open only toward the brachium conjunctivum. The two extremities of the curve, formed by cells, continue caudalward into two cell rows, which soon fuse together to constitute the caudal portion of the nucleus. This latter portion lies partly among the fibers of the brachium conjunctivum, partly caudoventral to the latter (fig. 21). The cells of both portions are now more numerous. . The caudal portion represents a compact nuclear mass; in the frontal part the cells are still scattered. 
Farther lateralward in our sagittal sections the form of the nucleus of the mesencephalic root of $V$ resembles somewhat that of an hourglass. The frontal portion of the nucleus is situated above the brachium conjunctivum, the caudal below the latter. Both are joined together by a few cells lying among the fibers of the brachium conjunctivum. In
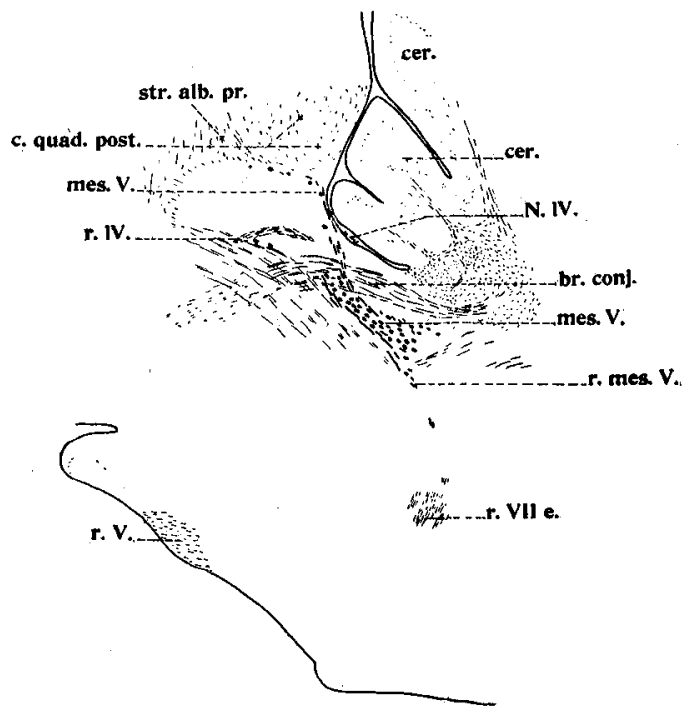

Fig. 21 Sagittal section through the tectal and pontine regions of an adult mouse, at the level of the brachium conjunctivum and the trochlear root. Chromsilver preparation. $\times 20 . \quad b r . c o n j$. , brachium conjunctivum; cer., cerebellnm; c.quad.post., corpus quadrigeminum posterius; mes.V., cells of the mesencephalic root of V; $N . I V$., troehlear nerve; r.IV., trochlear root; r.mes.V., mesencephalie root of $\mathrm{V} ; r . V$., trigeminäl root; r.VII.e., exiting portion of the seventh root; str.alb.pr., stratum album profundum.

the upper portion an arrangement of cells into small groups of two to four cells is evident, while the lower one forms a single compact nuclear mass. The upper is more rounded, the lower of a nearly triangular shape. One angle of the latter triangle is directed frontalward, one caudalward, toward the cerebellum, and one ventralward. The upper side of the triangle is oriented parallel to the brachium conjunctivum. The position of the caudal part of the lower 
portion of the nucleus corresponds to that of the frontal portion of the motor nucleus of $\mathrm{V}$.

Proceeding still farther lateralward in our sagittal series, we see that the two portions of the nucleus of the mesencephalic root of $\mathrm{V}$ become entirely separated from each other by the brachium conjunctivum. The upper portion decreases more and more and at last disappears. The lower portion remains still massive. It begins to decrease quite slowly in sections farther lateralward and disappears in the sagittal sections which pass approximately through the level of exit of the motor root of $\mathrm{V}$.

The fibers of the upper portion of the nucleus of the mesencephalic root of $\mathrm{V}$ are gathered into two larger bundles, one of which lies dorsal, the other ventral to the nucleus. The dorsal bundle is bordered by cells along its ventral side, the ventral bundle by cells along its dorsal portion. The direction of the fibers corresponds to the curved outline of the nucleus, which appears thus surrounded by the root. Each of the larger bundles consists of several smaller ones. Therefore, the fibers run in caudal direction and are eut longitudinally in sagittal sections. The main fiber masses of the mesencephalic root of $V$ are observed lateral to the trochlear root, only a few medial fibers being intermingled with this root. The roots cross each other almost at a right angle. Farther caudalward, the mesencephalic root of $\mathrm{V}$ crosses the brachium conjunctivum, piercing its way among the fibers of the latter. The cells of the nucleus of the mesencephalic root of $V$, which are located in this region, lie between the two bundles of the root. Caudal to the brachinm conjunctivum, at the level of the lower portion of the nucleus of the mesencephalic root of $\mathrm{V}$, the two bundles fuse together and turn lateralward. They run in this direction for a very short distance, after which they turn again caudalward and slightly ventralward toward the motor nucleus of $V$. The lower portion of the nucleus of the mesencephalic root of $\mathrm{V}$ lies, in greater part, dorsocaudal to the root; a portion of the cells are situated among the fibers. Having reached the 
level of the motor nucleus of $\mathrm{V}$, the mesencephalic root of $\mathrm{V}$ passing dorsal to this nucleus spreads out into several small bundles. These bundles turn sharply ventralward and enter successively the motor nucleus of $V$. Some of them swing ventralward around the caudal limit of this nucleus. The mesencephalic root of $V$ thus appears to join the motor root of $\mathrm{V}$.

The cells of the frontal portion of the nucleus of the mesencephalic root of $\mathrm{V}$ appear in our sagittal series nearly round in outline; the shape of those of the caudal portion is a more elongated one. The long axis of the caudal cells is oriented in a frontocaudal direction. In the frontal portion many cells of a relatively small size occur. All cells seem to be unipolar (fig. $35, k$.). The single process of the frontal cells is directed caudalward. This is also the case in caudal cells situated among the root fibers, while the processes of those cells, which lie dorsocaudal to the root, are directed frontalward. The root fibers are quite coarse and slightly tortuous. Very slender branches are seen to emanate from the fibers in the region of the motor nucleus of $V$.

In a sagittal and a horizontal series of chrom-silver preparations of a mouse embryo near term, the nucleus of the mesencephalic root of $\mathrm{V}$ is found, as in the adult animal, at the outer border of the periventricular gray of the aqueduct and of the IVth ventricle. In the region of the midbrain the cells are not numerous. Closely lateral to them lies the stratum album profundum. The root lies between this stratum and the cells of the mesencephalic root of $V$. In the region of the anterior medullary velum the nucleus of the mesencephalic root of $V$ of the embryo occupies, as in the adult, a more lateral position. The caudal limit of the nucleus reaches just the level of the motor V. Thus, it extends nearly as far caudalward as in the adult mouse. Dorsal and lateral to the nucleus in this region lies the brachium conjunctivum, medial to it passes the trochlear root. The nucleus of the mesencephalic root of $V$ in the embryo is also more massive in its caudal part. In some horizontal sections 
passing obliquely and just below the level of the trochlear decussation, the nucleus of the mesencephalic root of $V$ can be seen in its entire longitudinal extent (fig. 22). The frontal portion of the nucleus is formed by cells lying behind each other in a single row, which is slightly curved lateralward and extends from the region caudal to the posterior commissure into the pons to the level of the anterior medullary

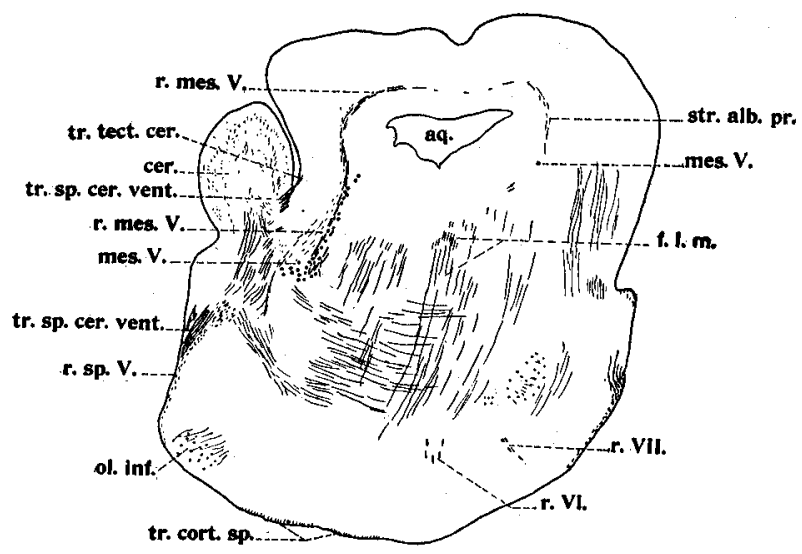

Fig. 22 Oblique horizontal section through the tectum and pons of a mouse embryo near term. On the right side of the figure the section is farther dorsal than on the left side. Chrom-silver preparation. $\times 20$. aq., aqueduct; cer., cerebellum; f.l.m., fasciculus longitudinalis medialis; mes.V., cells of the mesencephalie root of $\mathrm{V}$; ol.inf., oliva inferior; r.mes.V., meseneephalie root of $\mathrm{V}$; r.sp.V., spinal root of $\mathrm{V} ; r . V I$., root of the sixth nerve; r.VII., root of the seventh nerve; str.alb.pr., stratum album profundum; tr.cort.sp., tractus corticospinalis; tr.sp.cer.vent., tractus spinocerebellaris ventralis; tr.tect.cer., tractus tectocerebellaris.

velum. Lateral to the row, lie the fibers of the mesencephalic root of $\mathrm{V}$ and the stratum album profundum. The caudal extremity of the cell line deviates slightly lateralward and ends in a compact round nuclear mass representing the caudal portion of the nucleus (fig. 22).

The root fibers of the mesencephalic root of $\mathrm{V}$ lie in the region of the $I V$ th ventricle, ventral to the caudal portion of the nucleus. Its farther course is the same in the em- 
bryonic as in the adult mouse. As in the adult, the fiber masses run in the embryo dorsal to the motor nucleus of $V$ and are very clearly seen to split into several small bundles as they turn sharply ventralward, and so to enter the nuclear mass of motor $V$. A part of the fibers pass ventralward caudal to the motor nucleus of V. All fibers turn then lateralward and run in a ventrolateral direction to leave the brain apparently together with the fibers of the motor root of $V$.

In the embryo most of the cells of the nucleus of the mesencephalic root of $\mathrm{V}$ (fig. $35, f$.), are of an approximately round or ovoid form and provided usually with more than one process. The one process of the cell is relatively thick; it enters the root, which seems to be formed by these fibers. As the cells are situated either dorsal or medial to the root, the thick process runs at first for a very short distance ventralward or lateralward and then turns at a right angle to run caudalward. This process is often seen to give off slender branches, which run either in an opposite direction or accompany the main branch in its course caudalward. The slender branch arises, sometimes, from the thick process at the place where the latter makes its abrupt turn. The ramification is then a T-shaped one. Sometimes, the thick process gives origin to the slender branch only after its turn. The pole of the cell, from which the thick process arises, bears often a cone-shaped elongation. Occasionally, two or three processes can be observed to arise from this elongation, one of which processes is the above-described thick one. In addition to this process, the cell also gives origin to two to four very slender processes arising from all surfaces of the cell body and without apparent modifications of its more or less regularly rounded outline. In general, the processes are relatively short and extend in all directions, giving off in turn slender branches. Sometimes, however, the slender processes are traceable frontalward or dorsalward to distances relatively far from the cell body. Sometimes, they are seen to join the fibers of the stratum album profundum. Occasionally, they bifurcate at the end of their course. 
The cells of the nucleus of the mesencephalic root of $\mathrm{V}$ in mouse embryo appear multipolar in both sagittal and horizontal sections of our chrom-silver material (fig. $35, f$.). Cells in which only one process is observable are very infrequent in embryos. This is in marked contrast to the adult animal, where only unipolar cells were found. This observation of ours is in complete accord with the work on cell type of the nucleus of the mesencephalic root of $V$ carried out by Ramón y Cajal ('96), who states that the cells of the nucleus of the mesencephalic root of $\mathrm{V}$ are multipolar at early stages of development, while later they become unipolar, all processes except one gradually disappearing. In contradistinction to our observations and to those of the above-quoted author are the statements of Terterjanz ('99), according to whom the processes are more numerous and better developed in adult individuals than in young. It is possible that the latter author has considered as the cells of the nucleus of the mesencephalic root of $V$ those cells which, as Bickel ('02) and S. Ramón y Cajal ('09) suggest, do not belong exactly to this nucleus. Bickel points out that only the 'pear-shaped' or 'balloon-shaped' or 'vesiculoid' cells, the appearance of which corresponds to the description given by Meynert, can be regarded as neurones of the nucleus of the mesencephalie root of $V$. They are often intermingled with multipolar cells of quite a different aspect, the fibers of which are not seen to enter the mesencephalic root of $\mathrm{V}$ (Bickel; Ramón $\mathrm{y}$ Cajal). Terterjanz seems to have described and reproduced in his figures some of these multipolar cells, designating them as the neurones of the nucleus of the mesencephalic root of $V$. We agree with Bickel to this extent, that in adult mammals the cells of the mesencephalic root of $\mathrm{V}$, as seen in our material, are often-but not invariably-unipolar, and that some of the cells reproduced in the figures of Terterjanz do not resemble the cells of the mesencephalic root of $V$, but remind us more of those of the cells of the nucleus intratrigeminalis. Further, according to Ramón y Cajal, in mice the cells of the nucleus of the mesencephalic root of $V$ have 
a border of short spines which are always present in animals of three to four and also of eight to fifteen days, at which stages the short processes are already lacking. We could not observe these 'spines,' either in the adult mouse or in the embryo, the surface of the cell, in our preparations, appearing relatively smooth.

\section{The mesencephalic root of $V$ in the rat}

The nucleus of the mesencephalic root of $\mathrm{V}$ is found in the adult albino rat from the region just caudal to the posterior commissure to the level of the motor nucleus of V. It extends thus in longitudinal direction for a distance of about $3.25 \mathrm{~mm}$. Single cells of the nucleus of the mesencephalic root of $\mathrm{V}$ begin to appear in cross-sections passing just behind the posterior commissure, the frontal limit of the nucleus corresponding thus to that of the oculomotor nucleus. However, the cells of the mesencephalic root of $\mathrm{V}$ in this region are very few in number, not being present in certain of the sections. Caudalward, the number of cells increases. About $0.6 \mathrm{~mm}$. caudal to the first appearance of the cells of the mesencephalic root of $V$, their number becomes relatively constant to the number of four to eight cells in each cross-section, as observed in serial-cell count, and continues thus for a distance of about $0.8 \mathrm{~mm}$. in longitudinal direction, i.e., until a level about $0.25 \mathrm{~mm}$. caudal to the caudal limit of the trochlear nucleus. Serial counting here again evidences a slight increase. However, a more conspicuous increase is observed still farther caudalward at the level of the decussation of the trochlear nerve. Between this level and the region of the motor nucleus of $\mathrm{V}$, the mass of the nucleus of the mesencephalic root of $V$ is greatest as enumerated, about twenty to thirty cells for each side per section. Here also the cells are located most closely to each other. Their number begins to decrease quite rapidly soon after the motor nucleus of $V$ appears.

In the region of the midbrain the cells of the nucleus of the mesencephalic root of $\mathrm{V}$ are situated on both sides of the 
aqueduct, lateral to the latter. They can never be seen near the medial line nor dorsal to the aqueduct. Medial to the nucleus of the mesencephalic root of $\mathrm{V}$ lies the periventricular gray and lateral to it the transverse fibers of the corpora quadrigemina anteriora (stratum album profundum), a part of which forms the fountain decussation of Meynert (dorsal tegmental decussation). The dorsoventral extension of the nucleus of the mesencephalic root of $\mathrm{V}$ corresponds approximately to that of the aqueduct. In the frontal part of the nucleus the cells lie one above the other, the more dorsal ones being located, in general, slightly more laterally than the ventral ones. More caudalward, at levels where the number of cells of the nucleus of the mesencephalic root of $\mathrm{V}$ is increasing, the cells are arranged in small groups of two or three cells, which groups lie one above the other. The nucleus appears thus in cross-sections as a cell column lying' by the side of the periventricular gray of the aqueduct, descending sometimes lower than the ventral limit of the latter. The dorsal limit of the cell column lies usually below the level of the dorsal border of the aqueduct, but occasionally some cells are found slightly dorsal to this level. In general, the cell column of the nucleus of the mesencephalic root of $\mathrm{V}$ is situated in a nearly vertical or sometimes slightly oblique plane, since its dorsal end deviates a little lateralward. Some sections behind the caudal limit of the trochlear nucleus, the position of the cell column changes: its dorsal end lies now more medially, the ventral more laterally. In certain places the column is slightly curved, its concavity being directed medialward in the caudal part, while more frontally, where occasionally it is curved, the concavity is directed lateralward. Sometimes, the nucleus appears as a single oblique or curved cell line instead of a column and, in such cases, is composed of cells in a single row lying above each other. In some sections the nucleus is formed by a single cell line in its dorsal part, while the ventral part has the appearance of a column, being composed of small groups of two to three or four cells, lying above each other. The root 
fibers are located lateral to the nucleus. Beginning about $0.5 \mathrm{~mm}$. behind the caudal limit of the trochlear nucleus and extending for a distance of about $0.5 \mathrm{~mm}$., the nucleus of the mesencephalic root of $\mathrm{V}$ appears as a slightly curved line lying around the lateral limit of the periventricular gray of the aqueduct, chiefly at the level of the ventral half of the latter. Often the ventral limit of the nucleus lies lower than that of the aqueduct. About $1 \mathrm{~mm}$. caudal to the trochlear nucleus, its. form becomes that of a quite straight, vertical cell column, lying medial to the root fibers of the mesencephalic root of $\mathrm{V}$, at the outer border of the periventricular gray. The upper end of the column corresponds usually to the half of the dorsoventral extension of the aqueduct. The one half of the column lies thus by the side of this latter, while the other half is situated below the level of its ventral border. The nucleus of the mesencephalic root of $\mathrm{V}$ keeps such a position for a distance of about $0.45 \mathrm{~mm}$., i.e., to a level about $0.2 \mathrm{~mm}$. frontal to the anterior medullary velum, at which level the ventral end of the nucleus begins to deviate lateralward. The nucleus has now in cross-sections an approximately triangular shape, the base of the triangle is turned lateralward and ventralward, the apex medialward and dorsalward. The apex lies beside the ventrolateral angle of the aqueduct and, farther caudalward, beside the lateral border of the IVth ventricle. The triangular shape of the nucleus is due to the fact that its dorsal part is formed of a single row of cells, while, in its ventral part, the cells lie in two to four rows which spread out ventralward in fan shape. Sometimes, no regular cell rows are distinguishable in the ventral part of the nucleus, this latter forming a quite dense cell mass with a narrower upper part. In the caudal part of the midbrain the nucleus of the mesencephalic root of $V$ lies more ventral in relation to the aqueduct than it does in its more frontal part. In the region of the colliculus inferior, where the aqueduct begins to enlarge, the dorsal portion of the nucleus corresponds almost to the ventral limit of the aqueduct. In the region of the frontal part of the 
anterior medullary velum the nucleus loci coerulei ${ }^{6}$ begins, which nucleus lies medial to the nucleus of the mesencephalic root of $V$. The dorsal part of the nucleus of the mesencephalic root of $V$ lies close to the nucleus loci coerulei, so that the cells of the former cover somewhat those of the latter on the dorsolateral side. Farther caudalward, the nucleus loci coerulei increases in bulk and extends in ventral direction, forming, at the side of the IVth ventricle, a very distinct cell mass. The upper and lower borders of the nucleus loci coerulei, as seen in cross-sections, correspond approximately to those of the nucleus of the mesencephalic root of $V$. Both cell masses are in quite close relation to each other in their dorsal portions. They diverge ventralward, the nucleus loci coerulei maintaining a vertical position, while the nucleus of the mesencephalic root of $\mathrm{V}$ is directed lateralward. Both nuclei are traversed at first by some of the fibers of the brachium conjunctivum, which farther caudalward lies lateral to them. At the level of the motor nucleus of $V$, the nucleus of the mesencephalic root of $\mathrm{V}$ lies dorsal to the latter and medial to the sensory nucleus of $V$, the nucleus loci coerulei being always situated medial to the nucleus of the mesencephalic root of $\mathrm{V}$, between the latter and the IVth ventricle.

In sagittal sections passing through the region of the brachium conjunctivum and through that part of the nucleus of the mesencephalic root of $\mathrm{V}$ found at the level of the motor nucleus of $\mathrm{V}$, the former nucleus appears, as it does in cross-sections, of a somewhat triangular shape. However, in this plane the base of the triangle lies dorsally, being

- The formation lying ventral to the aqueduct, or of the floor of the fourth ventricle, and composed of irregular cells (pigmented in man) is termed by some authors (Meynert, '72; Forel, '77) 'substantia ferruginea,' by others 'nucleus loci coerulei' (Held, '93; Cajal, '09). Willems ('11) applies with regard to the rabbit the term 'substantia ferruginea' to the cell masses situated outside of the mesencephalic root of $V$, and the term 'nucleus loci coerulei' to the cell masses lying medial to this root. We have not made such a distinction, since no differences exist in the appearance or arrangement of the cells of this group located in certain forms partly lateral to the mesencephalic root of $V$, and those lying medial to it. Moreover, often the lateral and medial cell masses are continuous with each other. 
turned toward the brachium conjunctivum, while the apex is directed ventralward and caudalward toward the motor nucleus of $V$, following somewhat the course of the mesencephalic root of $V$.

In the rat the cells of the nucleus of the mesencephalic root of $V$ are mostly round or slightly elongated-of an oval or pear shape. Sometimes their form is slightly irregular or polygonal. Occasionally, a few kidney-shaped cells can be seen. The size of the cells varies between 15 and $30 \mu$. The average size is about $23 \mu$. A few cells of smaller size are found (about 13 to $15 \mu$ ). These smaller cells are not confined to any definite region of the nucleus, but are scattered throughout. Except for their size, they do not differ from the other cells of the nucleus. The tigroid substance is well differentiated and is more or less equally distributed in the form of granules throughout the whole cell body, giving it a granular appearance. The periphery of the cell body sometimes appears darker than the center. Although the cells of the nucleus loci coerulei lie in very close relation to those of the nucleus of the mesencephalic root of $V$, and although the cells of both nuclei are sometimes intermingled with each other, a differentiation of the two kinds of cells is very easy. The cells of the nucleus loci coerulei are usually smaller and mostly of a triangular shape, while those of the nucleus of the mesencephalic root of $V$ are usually round or oval. On the cells of the nucleus loci coerulei can be observed one to three processes, while on the cells of the nucleus of the mesencephalic root of $\mathrm{V}$ no processes are distinguishable in our toluidin-blue preparations. The cells of the nucleus of the mesencephalic root of $V$ have further a well-pronounced granular appearance, the clumps of tigroid substance being more or less equally distributed throughout the whole cell body. In the cells of the nucleus loci coerulei the tigroid clumps are less numerous, larger in size, and darker. Some cells of the nucleus loci coerulei are stained more or less diffusely, some reveal, beside a diffuse staining of the whole cell body, two to three dark tigroid clumps at the periphery. 
In some cells of the nucleus loci coerulei, the dark clumps form a continuous circle at the periphery of the cell, while other cells have a striped appearance. Neurones of a regular granular aspect can never be observed among the cells of the nucleus loci coerulei as is the rule in the cells of the nucleus of the mesencephalic root of $\mathrm{V}$.

In the region of the midbrain the cells of the nucleus of the mesencephalic root of $\mathrm{V}$ are intermingled with the small cells of the periventricular gray of the aqueduct and sometimes, also, with large multipolar cells. These latter correspond to the nucleus intratrigeminalis of Kohnstamm ('00). These latter cells are also very clearly distinguishable from the cells of the nucleus of the mesencephalic root of $V$. The cells of the nucleus intratrigeminalis are multipolar, of a triangular or irregular shape; the cell processes are always well seen. The tigroid substance does not form granulations equally disseminated throughout the cell body and often the cell has a striped appearance. The number of the cells of this kind, which come into a close contact with the cells of the nucleus of the mesencephalic root of $V$, is relatively small. An intermingling of both kinds of cells takes place mostly in the ventral part of the nucleus of the mesencephalic root of $V$, though a quite close relation can of ten be observed in its dorsal part, where the cells of the nucleus intratrigeminalis lie chiefly lateral to the nucleus of the mesencephalic root of $\mathrm{V}$, but sometimes also dorsal to its upper limit. According to Kappers ('20), the cells of the nucleus intratrigeminalis may be considered as a possible origin of the posterior commissure or of descending tectal paths. Edinger ('11) thinks that the axons of these cells are sent into the most caudal parts of the medulla oblongata.

In our chrom-silver preparations the cells of the nucleus of the mesencephalic root of $\mathrm{V}$ of the adult albino rat appear strictly unipolar. In a young rat of three days after birth, cells with more than one process occur, although the greater part of the cells seem to be unipolar. In bipolar cells of the young rat the processes arise often from the opposite poles 
of the cell body. The thicker of them enters the root. Cells with more than two processes are less frequent. Sometimes, the two or more processes take their origin from the same pole of the cell body. In the adult rat the single process of the cell is relatively thick and cannot be followed far from the cell body. However, it is seen to enter the mesencephalic root of $\mathrm{V}$. Ramifications of the cell process are not observed with certainty in our material. The root fibers generally are located lateral to the cells, lying close to and between the latter and the layer of transverse fibers of the corpora quadrigemina anteriora. However, some cells are located among the root fibers, but only a very few of them are found lateral to the root. In order to reach this root, the processes of most cells run lateralward. Having reached the root, they turn sharply caudalward, swinging at the same time slightly ventralward. They run then farther in a longitudinal direction, so that in cross-section they are cut mostly transversely or appear as very short fibers. At the level of the exit of the IVth nerve from its nucleus, some of the fibers of the mesencephalic root of $\mathrm{V}$ begin to turn into a slightly ventral direction. The root appears in cross-sections to be composed of several small bundles cut transversely and lying above each other. These bundles form thus a slightly curved line with the concavity turned medialward. The ventral extremity of this line is more curved and directed toward the trochlear root. The fibers of this latter run lateralward and dorsalward, after their exit from the nucleus. Farther caudalward, the root fibers of the mesencephalic root of $\mathrm{V}$ and the trochlear root are in a very close relation to each other. The former fibers are here directed ventralward and slightly medialward. As they continue in a longitudinal direction they appear shorter in cross-sections than do those of the trochlear root. Both roots form together a curve, lying around the periventricular gray of the aqueduct at its ventrolateral angle. However, the fibers of the trochlear root soon turn into a longitudinal direction and they are then cut transversely in cross-sections (fig. 23). At the same 
time the root fibers of the mesencephalic root of $\mathrm{V}$ begin to turn more noticeably ventralward (fig. 23). A portion of them runs medial to the trochlear root, but the main fiber masses interlace with the trochlear root (fig. 23). In sections passing thus just in front of the anterior medullary velum the trochlear root is, in cross-sections, cut transversely, while the fibers of the meseneephalic root of $V$ are

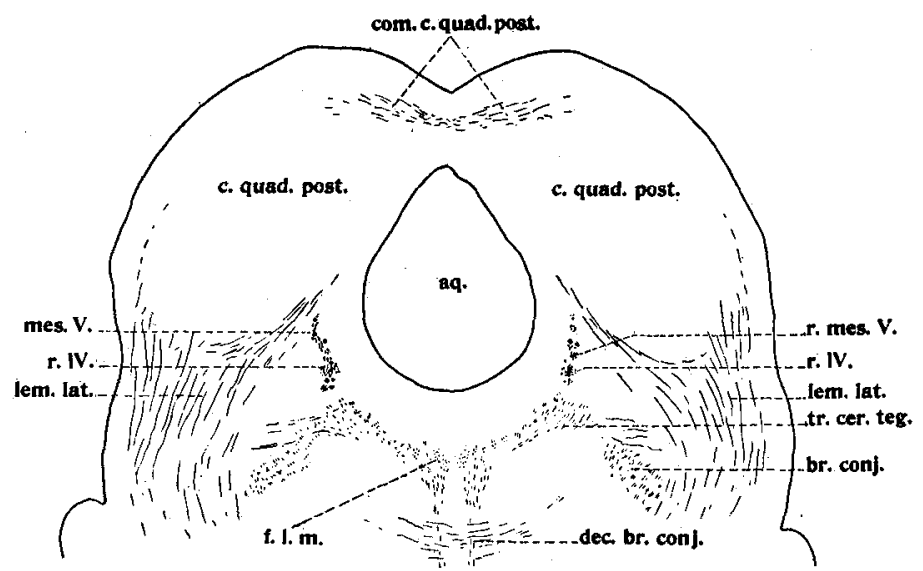

Fig. 23 Cross-section through the corpora quadrigemina posteriora of an adult rat. The section is caudad to the trochlear nucleus. Chrom-silver preparation. $\times 12$. aq., aqueduct; br.conj., brachium conjunetivum; com.c.quad.post., commissura corporum quadrigemin. posteriorum; c.quad.post., corpus quadrigeminum posterius; dec.br.conj., decussatio brachii conjunctivi; f.l.m., fasciculus longitudinalis medialis; lem.lat., lemnisens lateralis; mes.V., cells of the mesencephalic root of $\mathrm{V} ; r . I V$., trochlear root; r.mes.. ., mesencephalie root of $\mathrm{V}$; tr.cer:teg., tractus cerebellotegmentalis.

seen to traverse these fibers and to run ventralward. Ventral to both roots lies the brachium conjunctivum. At the level of the beginning of the anterior medullary velum, the fibers of both roots appear still more intermingled with each other. This is due to the fact that the trochlear root turns here into a dorsal direction and its fibers, as well as those of the meseneephalic root of $\mathrm{V}$; are cut longitudinally in cross-sections. The most ventral fibers of the mesencephalic 
root of $\mathrm{V}$ in this region cross the fibers of the brachium conjunctivum. They turn slightly medialward, maintaining at the same time their ventrocaudal direction. Behind the level of the decussation of the trochlear nerve, the root fibers of the mesencephalic root of $\mathrm{V}$ lie medial to the greater part of the brachium conjunctivum and lateral to the nucleus of the mesencephalic root of $\mathrm{V}$. Medial to this latter lies the nucleus loci coerulei. A part of the fibers of the brachium conjunctivum are still situated medial to the root and nucleus. Farther caudalward the brachium conjunctivum lies entirely lateral to the root fibers of the mesencephalic root of $V$. The fibers of this latter turn here very slightly lateralward and take again a more longitudinal direction. They reach thus the level of the motor nucleus of $\mathrm{V}$. Slender branches are seen to arise in this region from the fibers of the mesencephalic root of $V$. However, the course of these branches cannot be traced far from their place of origin. From here on, the root takes a ventral course. Some of its fibers are clearly seen to run toward the motor nucleus of $V$, joining thus the motor root of $V$. Some of them pass in a slightly curved line (as seen in sagittal sections) between the motor and the sensory nucleus of $V$. They leave the brain lying between the two roots. Whether the root fibers of the mesencephalic root of $V$ also join the sensory root of $\mathrm{V}$ cannot be decided with certainty in our material.

\section{The mesencephatic root of $V$ in the cat}

In the cat the nucleus of the mesencephalic root of $V$ extends from the region of the distal part of the posterior commissure backward until the level of the frontal part of the motor nucleus of $V$. Its whole frontocaudal extension is about $11 \mathrm{~mm}$. The most proximal cells of the nucleus of the mesencephalic root of $\mathrm{V}$ are found about $0.45 \mathrm{~mm}$. in front of the caudal limit of the posterior commissure or about $1 \mathrm{~mm}$. in front of the proximal limit of the magnocellular portion of the oculomotor nucleus. However, only a few cells of the nucleus of the mesencephalic root of $V$ are located 
frontal to the caudal limit of the posterior commissure. The number of cells begins to increase quite noticeably distal to the posterior commissure, and the main cell masses are found at the level of the oculomotor nucleus, where there are from ten to twenty cells in each cross-section. In the region of the caudal part of the oculomotor nucleus the number of cells of the nucleus of the mesencephalic root of $\mathrm{V}$ begins to decrease; however, they are still quite numerous in sections passing through the frontal part of the trochlear nucleus, but are few in sections through the caudal part of this nucleus. Distal to the trochlear nucleus and in the proximal part of the region of the anterior medullary velum, i.e., for a distance of about $2.5 \mathrm{~mm}$., the number of cells of the $\mathrm{nu}$ cleus of the mesencephalic root of $\mathrm{V}$ is relatively small, perhaps one to five cells on either side, as seen in crosssection. Just in front of the trochlear decussation, the nucleus of the mesencephalic root of $\mathrm{V}$ increases again quite abruptly and the number of its cells is great again for a distance of about $1.25 \mathrm{~mm}$. Here, there are found ten to fifteen cells on either side in each section, as determined by serial count.

Caudal to the exit of the trochlear nerve, the number of cells of the nucleus of the mesencephalic root of $V$ begins to decrease quite slowly. Although few in number, these cells can be observed until the level of the motor nucleus of $\mathrm{V}$, and even in some sections through the frontal part of this nucleus.

The largest relative number of cells of the nucleus of the mesencephalic root of $\mathrm{V}$ is observed, thus, in the region of the oculomotor and the frontal part of the trochlear nucleus. This augmentation begins about $1 \mathrm{~mm}$. caudal to the frontal limit of the nucleus of the mesencephalic root of $V$ and extends backward for a distance of about $3.5 \mathrm{~mm}$. Another augmentation of the nucleus is found at the level of the trochlear decussation. The latter augmentation does not extend so far as the former, reaching in longitudinal direction only $1.25 \mathrm{~mm}$., but the number of cells in each section is here almost as great as in the region of the oculomotor nucleus. 
The most frontal cells of the nucleus of the mesencephalic root of $V$ are situated at the medioventral border of the posterior commissure, at the outer limit of the periventricular gray of the aqueduct. They do not lie here in very close relationship to one another and are, in general, arranged in a curved line along the medioventral border of the posterior commissure. In relation to the aqueduct, the situation of the nucleus of the mesencephalic root of $V$ corresponds here approximately to the middle third of the dorsoventral extension of the former. Besides cells located at the outer limit of the periventricular gray, there are found, in some sections passing through the caudal part of the posterior commissure, a few cells of the nucleus of the mesencephalic root of $\mathrm{V}$ which lie dorsal to this commissure, between it and the transverse fibers of the corpora quadrigemina anteriora (the commissura corporum quadrigeminum anteriorum). These cells are situated close to the ventral border of the latter fiber masses. This part of the nucleus of the mesencephalic root of $V$ thus lies on a level dorsal to the aqueduct. The cells of this region also form a curved line with the concavity turned medialward and mostly ventralward. The orientation of this line is thus mediolateral, while the cell line below the posterior commissure is nearly vertical. The appearance and size of cells of both parts of the nucleus are the same.

Caudal to the level of the posterior commissure, the nucleus of the mesencephalic root of $\mathrm{V}$ is found at the ventral border of the layer of transverse fibers of the corpora quadrigemina anteriora. The cells are here already more numerous and form, as before, a curved line along this layer. They are located at a level dorsal to the aqueduct, but do not reach the median line. The inward-curved cell row extends in a ventrolateral direction and its ventral limit corresponds approximately to the level of the small lateral recess of the aqueduct (this recess is found approximately at the ventral limit of the upper third of the aqueduet). At the level of this recess the cell line makes a quite abrupt turn 
medialward. The cells are, in general, more removed from each other in the dorsal part of the nucleus than in the ventral. In the former part the cells are mostly arranged in a single row, while more ventrally the row becomes less regular, the cells being often organized into small groups of two to four cells. Therefore, the nucleus appears larger in its ventral part. It is especially so in the place where the line bends medialward. The cells lie here not only above each other, but also side by side. Farther caudalward, the dorsally situated cells of the nucleus of the mesencephalic root of $\mathrm{V}$ more nearly approach the median line; they are found sometimes relatively near to it, but are never located in the median line itself, a distance of about 0.3 to $0.5 \mathrm{~mm}$. or more being usually noticeable between the latter and the most medially placed cells. The abrupt bend in the curve at the level of the lateral recess of the aqueduct becomes smoother in more distal sections and, beginning at the frontal limit of the oculomotor nucleus, the nucleus of the mesencephalic root of $\mathrm{V}$, as it extends backward, represents a quite regular curve around the periventricular gray at the ventral and medial border of the layer of transverse fibers of the corpora quadrigemina anteriora. The lower end of the nucleus corresponds to the level of the upper limit of the ventral third of the aqueduct. At the same time the arrangement of cells into small groups, comprising two to four cells, becomes more pronounced. However, this grouping remains more evident in the ventral part of the nucleus, while in its dorsal portion the cells are, in general, still more scattered. The situation of the cells is, for the most part, confined quite definitely to the border of the periventricular gray. Occasionally, however, on either side of the line they are seen either among the transverse fibers of the corpora quadrigemina anteriora or deeper in the periventricular gray. This variation in position is found especially with cells lying in groups. The deviation of cells from the line of the outer border of the periventricular is not great, and it does not influence essentially the almost regularly curved outline of 
the nucleus. In the region of the caudal part of the oculomotor nucleus the cells of the nucleus of the mesencephalic root of $\mathrm{V}$ begin to swing away from the median line. The nucleus lies here on both sides of the aqueduct in the same relation to the periventricular gray as before, and its upper limit is still dorsal to the level of the aqueduct. The lower limit of the nucleus now is situated farther ventralward, sometimes it corresponds to the ventral border of the aqueduct. The cells are still often arranged in small groups, but as they extend caudalward they decrease in number and this grouping becomes less pronounced. Likewise, the curvature of the cell line straightens out more and more and takes a more vertical position at these levels, while in more frontal regions the inward-curved cell line was directed ventrolateralward in its dorsal part and ventromedialward in its ventral portion.

Caudal to the oculomotor nucleus, the nucleus of the mesencephalic root of $\mathrm{V}$ lies lower and lower in relation to the aqueduct. At the beginning of the trochlear nucleus, the cells are seen still dorsal to the aqueduct. At the level of the middle of the trochlear nucleus, where the nucleus of the mesencephalic root of $\mathrm{V}$ is decreasing, the most dorsal cells are located at the level of the upper surface of the aqueduct. In the region caudal to the trochlear nucleus, the upper limit of the nucleus of the mesencephalic root of $V$, in general, corresponds to the ventral third of the dorsoventral extension of the aqueduct. The nucleus of the mesencephalic root of $\mathrm{V}$ is situated here between the corpora quadrigemina posteriora and the periventricular gray. Closely lateral to the nucleus of the mesencephalic root of $V$ lies the root of this complex, and lateral to this latter and near to the medial side of the nucleus colliculi inferioris, is a narrow band of white substance representing the inner part of the lateral lemniscus.

In the region of the anterior medullary velum, especially at levels immediately in front of the trochlear decussation, the nucleus of the mesencephalic root of $V$ becomes more 
compact. The cells lie here in a more close relationship to each other and the groups into which they are organized are larger, consisting of five to seven cells. Also, the groups are situated nearer to each other, so as apparently to fuse together to form a single cell mass. In this region lateral to the nucleus, lies the trochlear root, medial, as yet, to the periventricular gray of the aqueduct, which latter opens here into the IVth ventricle and is already considerably larger in transverse direction, but narrower in the vertical. Ventral to the lower limit of the nucleus of the mesencephalic root of $\mathrm{V}$ lies the nucleus loci coerulei. This latter nucleus is medial with reference to the nucleus of the mesencephalic root of $\mathrm{V}$, therefore coming in contact with the nucleus of the mesencephalic root of $\mathrm{V}$ only on its lateral border (fig. 24, left side). Lateral to the nucleus loci coerulei, but also in very close relationship with the ventral limit of the root and nucleus of the mesencephalic root of $V$, lies the brachium conjunctivum, which in more caudal regions is situated more dorsally and thus lateral to the root fibers of the mesencephalic root of $V$ (fig. 24, right side). The form of the nucleus of the mesencephalic root of $\mathrm{V}$ is here somewhat different. In most cross-sections through this region the nucleus represents a vertical cell column; sometimes this column is slightly curved, the concavity being directed either lateralward or medialward. In some cross-sections the upper extremity of the nucleus of the mesencephalic root of $\mathrm{V}$ is situated laterally and above the level of the anterior medullary velum in the medial part of the corpus quadrigeminum posterius (fig. 24, left side), while the lower end is turned medialward toward the nucleus loci coerulei. In this region the ventral part of the nucleus represents usually a more compact cell mass, while the dorsal part is often found as a single cell row. Sometimes the upper part of the nucleus, instead of being directed lateralward, is directed medialward toward the lateral angle of the aqueduct. It lies ventral and medial to the trochlear root. In some sections the nucleus of the mesencephalic root of $\mathrm{V}$ appears as a quadrangular or 
round mass lying by the side of the lateral angle of the aqueduct.

Farther caudalward, the nucleus of the mesencephalic root of $\mathrm{V}$ lies in a more close contact with the nucleus loci coerulei. The latter is situated now partly medial to the former and lateral to the IVth ventricle. However, the greater part of the nucleus loci coerulei is situated lower than the nucleus of the mesencephalic root of $\mathrm{V}$, partly ventral to this nucleus, partly ventral to the root fibers of the mesencephalic

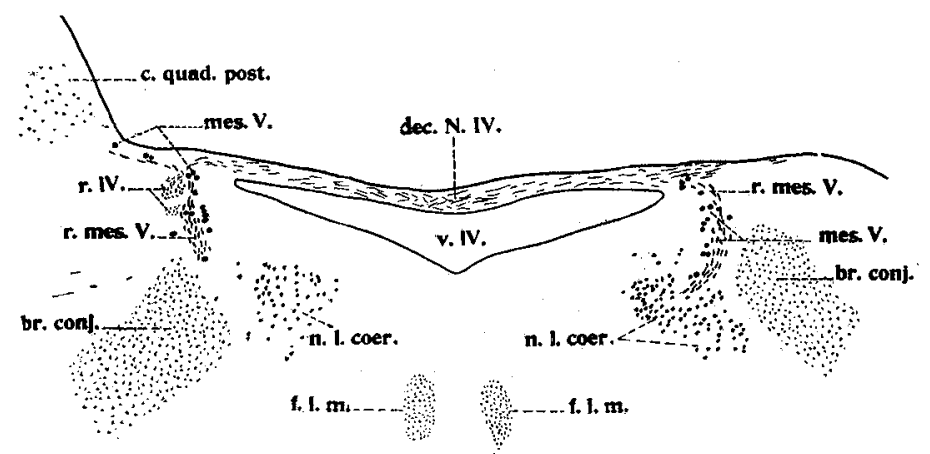

Fig. 24 Cross-section through the level of the trochlear decussation of cat. The section is farther caudal on the right side of the figure than on the left side. Toluidin-blue preparation. $\times 11$. br.conj., brachium conjunetivum; c.quad.post., corpus quadrigeminum posterius; dec.N.IV., decussation of the trochlear nerves; f.l.m., fascieulus longitudinalis medialis; mes.V., cells of the mesencephalic root of $\mathrm{V}$; n.l.coer., nucleus loci coerulei; r.IV., trochlear root; r.mes. $F$. , mesencephalic root of $\mathrm{V}$; v.IV., fourth ventricle.

root of $V$. The nucleus loci coerulei lies thus in its frontal part below the aqueduct and the IVth ventricle, while more caudally, it is partly at the side of the IVth ventricle, its main masses, however, being located lower than the lateral angle of the latter.

At the level of the motor nucleus of $\mathrm{V}$ and immediately in front of it, the cells of the nucleus loci coerulei are less in number and the nucleus of the mesencephalic root of $\mathrm{V}$, lying by the side of the lateral angle of the IVth ventricle, is limited medially partly by these cells and partly by the 
periventricular gray. Lateral to the nucleus of the mesencephalic root of $\mathrm{V}$ lies the root, and lateral and partly also dorsolateral to this latter, the brachium conjunctivum. The cells of the nucleus of the mesencephalic root of $V$ are not numerous in this region and they do not descend ventralward, as in the rat, but form mostly a short vertical line of cells, situated above each other.

In general, the root fibers of the mesencephalic root of $V$ are situated lateral to the cells. A few cells are seen only occasionally among the root fibers or lateral to the same (fig. 24). The lateral position of cells in relation to the root fibers is a little more frequent in the caudal part of the nucleus than in the frontal portion.

In the cat the cells of the nucleus of the mesencephalic root of $V$ vary somewhat in size and shape, according to the region considered. In the frontal part of the nucleus, from its frontal limit until the region of the proximal part of the trochlear nucleus, the cells are mostly oval or round. As concerns their size, there can be distinguished two types of cells in this portion. The one (fig. 34, d.) represents an average size of 20 to $30 \mu$ and is found chiefly in the dorsal. part of the nucleus. These cells have an approximately round outline in the sections. In this dorsal part of the nucleus cells of larger size are found only occasionally. The small cells lie mostly in a row dorsal to the aqueduct, along. the ventral border of the transverse fibers of the corpora quadrigemina anteriora. Sometimes, they are found arranged in small groups. The larger cells (fig. 34 , e.), of a diameter of 25 to $35 \mu$ in their shorter axis and of 30 to $50 \mu$ in their longer axis, are located mostly at the level of the aqueduct. Their shape is, in general, more elongated and they, more frequently than the small cells, are found arranged into groups. All degrees of transition in size occur from the small cells to the large ones. Van Valkenburg ('11), who also has observed the small cells of the nucleus of the mesencephalic root of $V$ in the cat and in rodents, considers them as less differentiated forms. This author 
expresses himself in favor of the opinion that the small cells also give origin to root fibers of the mesencephalic root of $\mathrm{V}$, since by their typical position and appearance they do not differ from the larger ones. This seems to us to be at least very probable. The arrangement of tigroid substance is the same in both types of cells. It is equally distributed throughout the whole cell body. Usually no darker circles can be observed, either at the periphery or at the center of the cell. The tigroid appears mostly in the form of small granules, thus giving to the cell a granular aspect. Occasionally the center of the cell body, around the nucleus, can be found diffusely stained. The cell nucleus is relatively pale. The multipolar cells of the nucleus intratrigeminalis of Kohnstamm in the eat do not intermingle so much with the cells of the nucleus of the mesencephalic root of $V$, as observed and noted for the rat. In the cat they are usually situated more laterally.

In the region of the distal part of the trochlear nucleus and caudalward until the level of the trochlear decussation, the form and aspect of the cells of the nucleus of the mesencephalic root of $V$ have changed somewhat. The cells here being few in number, are of a relatively smaller size and of an elongated, fusiform shape (fig. 34, e.). Their shorter axis is from 12 to $26 \mu$, their longer from 30 to $42 \mu$. They appear in our toluidin-blue preparations as very darkly and diffusely stained, so that the tigroid granules are not easily distinguishable in their cell body. Occasional cells of this type can be observed in regions frontal and caudal to levels where the type is predominant; in such locations these cells are found among the others usually in the ventral part of the nucleus of the mesencephalic root of $V$. However, these fusiform cells apparently are lacking in the most frontal, as well as the most caudal, part of the nucleus of the mesencephalic root of $\mathrm{V}$.

The cells of the nucleus of the mesencephalic root of $V$, caudal to the frontal limit of the trochlear decussation, are also quite deeply stained in our preparations; however, 
tigroid granulations are more easily distinguishable in them. A more deeply stained circle is sometimes seen surrounding the cell nucleus. The cells are mostly of a round or oval shape, less elongated than even the most frontal cells. Their diameter is about 30 to $40 \mu$. These cells are sometimes intermingled with the multipolar cells of the nucleus loci coerulei, from which they can be readily distinguished. The cells of the latter nucleus are, in general, smaller, multipolar, of irregular shape, and often of a striped appearance.

In our toluidin-blue preparations there can be seen occasionally in cells of all parts of the nucleus of the mesencephalic root of $\mathrm{V}$ a single process directed toward the root. The process is relatively thick and short and does not contain tigroid, either in cells of the frontal or in those of the caudal part of the nucleus. However, it appears sometimes stained in the fusiform cells of the middle portion. In the round small cells of the frontal part of the nucleus of the mesencephalic root of $V$, cell processes cannot be observed in our material.

The long axis of the cells is orientated mostly ventralward and lateralward. The ventral direction of the long axis is more pronounced in the fusiform cells of the region of the corpora quadrigemina posteriora, where its orientation is often almost vertical, while the more caudal cells in the region of the trochlear decussation are situated sometimes with their long axis in a transverse direction.

In comparison with the rat, the nucleus of the mesencephalic root of $\mathrm{V}$ in the cat reveals the following differences. The position of the nucleus in cat is more dorsal in the region of the corpora quadrigemina anteriora and, partly, posteriora. While in the rat the upper limit of the nucleus of the mesencephalic root of $\mathrm{V}$, in general, did not extend above the level of the aqueduct, a part of the cells are located in the cat dorsal to this latter, and approach the median line more nearly than in the rat. In the adult rat the main nuclear masses were found between the level of the trochlear decussation and the motor nucleus of $V$. In the cat the cells 
are more numerous in the region of the oculomotor nucleus, though an augmentation is evident also in the region of the trochlear decussation. In the cat the cells in the region of the corpora quadrigemina posteriora are fewer in number and of an elongated shape. Such a decrease, as well as such a difference in shape, was not evident in this region in the rat. Further, in the region of the motor nucleus of $V$ the cells of the nucleus of the mesencephalic root of $V$ are more numerous in the rat than in the cat. The small round cells of the frontal portion of the nucleus in the cat are more or less concentrated within the dorsal region of the nucleus. Such a localization of the small cells was not so obvious in the rat, where they were more scattered throughout the whole nuclear mass.

In the relation to the nucleus loci coerulei the nucleus of the mesencephalic root of $\mathrm{V}$ in the cat lies more dorsally, while in the rat both nuclei were situated at the same level. The trochlear root in the rat was partly interlaced with the root fibers of the mesencephalic root of $\mathrm{V}$, partly located lateral to it. In cat, as in some other Carnivora, in Artiodactyla, and in Chiroptera (Hulles, '07), the mesencephalic root of $\mathrm{V}$ lies medial to the trochlear root. Duval ('78) found in rodents studied by him (rat and rabbit) that the trochlear root is traversed by the mesencephalic root of $V$. This agrees with our observations in the rabbit, mouse, and rat.

The mesencephalic root of $V$ in monkey

In the monkey the nucleus of the mesencephalic root of $\mathrm{V}$ extends caudalward from the level of the frontal limit of the posterior commissure and of the oculomotor nucleus to the beginning of the motor nucleus of $\mathrm{V}$. Its whole longitudinal extent is thus about $9.5 \mathrm{~mm}$. A very few cells of the nucleus of the mesencephalic root of $\mathrm{V}$ are found slightly (about $0.15 \mathrm{~mm}$.) frontal to the level of the posterior commissure, at the outer border of the periventricular gray of the IIIrd ventricle. The cells are still quite few in number 
in the region of the proximal third of the corpora quadrigemina anteriora, i.e., for a distance of about $1.7 \mathrm{~mm}$. beginning from the frontal limit of the nucleus of the mesencephalic root of $\mathrm{V}$, as determined by serial-cell count. Only one to four cells are observed in each section through this region, and in many sections they are not present. at all. The situation of this portion of the nucleus corresponds, in general, to the middle third of the dorsoventral extension of the aqueduct. However, occasional cells are seen ventral to the level of the latter and in quite close relationship to the nucleus of the posterior commissure. The cells of the most frontal region of the midbrain are situated medial to the fibers of the posterior commissure, between the latter and the periventricular gray of the aqueduct. Caudal to the posterior commissure the cells lie between the periventricular gray and the stratum album profundum. They are found mostly in the place where the fibers of this stratum curve ventromedialward. The cells lie either just in the angle formed by this bend of fibers or closely dorsal or ventral to it. Lateral and ventral to the nucleus of the mesencephalic root of $\mathrm{V}$, the large multipolar cells of the nucleus intratrigeminalis of Kohnstamm ('00) are frequent. They are located among the fibers of the posterior commissure and those of the stratum album profundum.

In the region of the proximal part of the middle third of the corpora quadrigemina anteriora the cells of the nucleus of the mesencephalic root of $\mathrm{V}$ begin to increase in number. For a distance of about $1 \mathrm{~mm}$. in this region, about five to seven cells are found on either side in each cross-section The main accumulations of cells are observed, as before, close to the bend of the fibers of the stratum album profundum, corresponding to the level of the middle third of the dorsoventral extension of the aqueduct. However, some cells are located dorsal to the level of the aqueduct, and cells in a more ventral position are also more frequent in this region, the ventral limit of the nucleus corresponding often to that of the aqueduct. Ventral to the level of the latter, 
the cells are still very scarce. The cells at the level of the middle third of the aqueduct are arranged in closer relationship to one another than those of the rest of the nucleus. Sometimes, they form groups of two to seven cells and are not always strictly confined to the outer border of the periventricular gray, but lie sometimes slightly farther lateralward among the fibers of the stratum album profundum or a little deeper in the periventricular gray. The more ventral, as well as the more dorsal, cells are limited quite clearly to the inner border of the stratum album profundum. They are more scattered and do not form larger groups. Only occasionally a clustering into small groups of two cells is observable in the dorsal part of the nucleus. The whole nucleus represents thus a curve with the concavity turned toward the aqueduct and reveals a more abrupt bend at the level of the middle third of the latter.

About $2.7 \mathrm{~mm}$. caudal to the frontal limit of the nucleus of the mesencephalic root of $V$, i.e., in the proximal part of the distal half of the corpora quadrigemina anteriora, the number of cells begins to increase more noticeably. This increase is observable for a distance of about $0.5 \mathrm{~mm}$., after which from twenty to thirty-five cells are present on either side in each cross-section for a distance of about $2.9 \mathrm{~mm}$., i.e., in the caudal part of the corpora quadrigemina anteriora and in the frontal part of the corpora posteriora, as determined by serial-cell count. At the same time that the number of cells increases, the nucleus extends farther dorsalward. The ventral border of the nucleus corresponds to that of the aqueduct, but its dorsal limit lies now above the level of the latter without reaching, however, the median line. The cells form thus a curved line at the inner border of the stratum album profundum with an enlargement at the level of the middle third of the dorsoventral extension of the aqueduct. The groups of cells are here already larger than in the frontal half of the corpora quadrigemina anteriora. In the region where the nucleus of the mesencephalic root of $\mathrm{V}$ is largest, the cells extend still farther dorsalward. The curved cell 
lines of both sides approach each other above the aqueduct, their dorsomedial extremities being situated sometimes very close to the median line (fig. 25). A few cells are observed

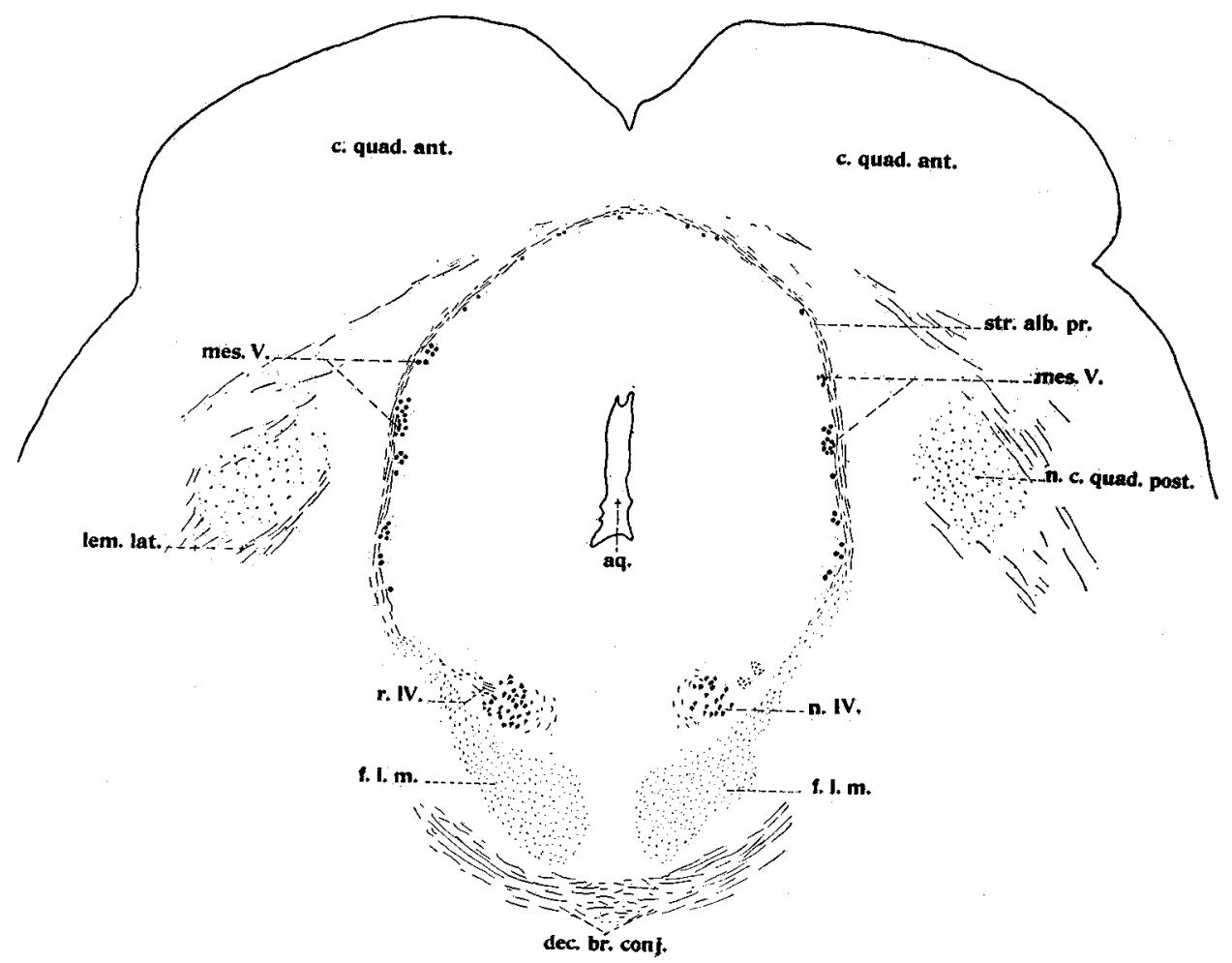

Fig. 25 Cross-section through the level of the trochlear nucleus of monkey (Macaeus rhesus). Toluidin-blue preparation. $\times 11$. aq., aqueduet; c.quad.ant., corpus quadrigeminum anterius; dec.br.conj., decussatio brachii conjunctivi; f.l.m., fasciculus longitudinalis medialis; lem.lat., lemniscus lateralis; mes.V., cells of the mesencephalic root of $\mathrm{V}$; n.c.quad.post., nucleus corporis quadrigemini posterioris; n.IV., trochlear nucleus; r.IV., trochlear root; str.alb.pr., stratum album profundum.

even in the median line itself and the two curves form then together an arch dorsal and lateral to the aqueduct. The ventral limit of this arch corresponds in general to that of the aqueduct; only occasionally are cells found ventral to this level. These cells approach closely the oculomotor nu- 
cleus and the trochlear nucleus. Large cell groups are now observed at the level of the dorsal half of the aqueduct. They are composed of ten to fifteen cells, lying very close to each other. The shape of the groups is round or angular. They represent, in general, quite compact nuclear masses, but sometimes the cells are arranged in the form of a rosette at the periphery of the group, the center being occupied by the corresponding root fibers. Sometimes, a group is formed by two vertical cell rows lying parallel to the aqueduct, a fiber bundle of the mesencephalic root of $\mathrm{V}$ being situated between the two rows (fig. 25). Sometimes, the shape of a group suggests that of a horseshoe, open lateralward. The cells of the dorsal part of the nucleus are scattered (fig. 25). The groups are here smaller and not in such a close relationship to one another. The cells of the ventral part of the nucleus (at the level of the ventral half of the aqueduct) are still more scattered and a grouping is here even less pronounced, except in the region of the corpora quadrigemina posteriora, where relatively large groups can be found occasionally in the ventral portion of the nucleus.

Approximately at the level of the frontal limit of the tuberculum quadrigeminum posterius, the more abrupt bend in the curved cell line of the nucleus of the mesencephalic root of $\mathrm{V}$ corresponds nearly to the level of the dorsal limit of the aqueduct. Caudalward, this bend is situated still farther dorsally, while in more frontal regions of the midbrain its position corresponded, as has been described, approximately to the middle third of the aqueduct. The cells by the side of the aqueduct are arranged now in a vertical column parallel to the latter, while the dorsal cells form a curve with the concavity turned ventralward (fig. 25). Both parts join at a smooth angle-representing the above-described bend. The cells of the vertical part are still the more numerous and form the larger and more compact groups. Lateral to these cells lie the root fibers of the mesencephalic root of $V$, and lateral to these the stratum album profundum. The relation of the cells to the deep medullary substance 
and to the periventricular gray is here the same as in more frontal portions of the nucleus; the dorsal cells being more exactly confined to the outer border of the periventricular gray. Farther caudalward in the region of the corpora quadrigemina posteriora, the dorsal cells disappear almost entirely. The nucleus of the mesencephalic root of $\mathrm{V}$ represents now two vertical, slightly inwardly curved cell columns lying on each side of the aqueduct, between the periventricular gray and the nucleus colliculi inferioris. The ventral limit of the cell column corresponds in the frontal part of the colliculus inferior to that of the aqueduct. In the caudal part of the colliculus inferior the position of the column corresponds nearly to the dorsal half of the aqueduct, only occasional cells being situated higher than the level of the latter. Sometimes, these are quite close to the ventral border of the commissura colliculi inferioris. In general, the root fibers of the mesencephalic root of $\mathrm{V}$ lie lateral to the cells. However, some cells are located among the fibers and also lateral to them. In the region of the corpora quadrigemina posteriora the cells are more frequently arranged into two parallel cell rows. The root is then enclosed between these two rows. Also in this region a slight decrease of the number of cells is evident for a distance of about $0.5 \mathrm{~mm}$., after which the cells again appear in greater number, when, for a distance of about $0.35 \mathrm{~mm}$. twenty to sixty cells are found then on either side in each cross-section. This last augmentation ceases approximately at the level of the trochlear decussation. The decrease of the cell number is a quite abrupt one in the region of the latter and the number remains then small (five to fifteen cells in each section) until the end of the nucleus-however, without revealing any considerable further decrease for a distance of about $2 \mathrm{~mm}$, i.e., until a level about $0.25 \mathrm{~mm}$. frontal to the motor nucleus of $\mathrm{V}$.

In sections passing caudal to the trochlear nucleus the nucleus of the mesencephalic root of $V$ lies dorsal and lateral to the trochlear root, the fibers of which run here in a longitudinal direction. Still more ventral to this nucleus is situ- 
ated the brachium conjunctivum which, in more caudal sections, lies closer to the former. The root fibers of the nucleus of the mesencephalic root of $V$, in cross-sections, is a vertical band having a slightly inward curve. It lies lateral to its cells of origin and its ventral extremity reaches to the brachium conjunctivum. Lateral to the root, between the latter and the nucleus colliculi inferioris, are located the internal fibers of the lateral lemniscus. These fibers swing medialward and dorsalward around the ventral border of the nucleus colliculi inferioris. They are situated very close to the root fibers of the mesencephalic root of $V$, in the dorsal part of the latter, and form therefore, together with this root, a sharp angle open ventralward. The main cell masses of those cells of the nucleus of the mesencephalic root of $\mathrm{V}$, which lie parallel to the dorsal half of the aqueduct, are limited in general on the lateral side by the internal fibers of the lateral lemniscus. In addition to these, occasional cells are found also in the nucleus tuberculi posterioris, dorsolateral to those fibers of the lateral lemniscus mentioned above. Farther caudalward, the trochlear root, the fibers of which run still in a longitudinal direction, lies medial to the ventral limit of the nucleus of the mesencephalic root of $V$. Here also, occasional cells are seen in the dorsal part of the corpora quadrigemina posteriora, sometimes quite close to the median line. In the caudal part of the corpora posteriora the cell groups of the nucleus of the mesencephalic root of $\mathrm{V}$ begin to fuse together, so that very often the cells lying by the side of the aqueduct form a single nuclear mass.

Just in front of the trochlear decussation the main masses of the nucleus of the mesencephalic root of $V$ lie at a level dorsal to that of the aqueduct. The trochlear root lies medial to the ventral part of the nucleus, at the level of the dorsal limit of the aqueduct. Sometimes in very close relationship to the nucleus of the mesencephalic root of $V$, and ventral to it, lies the medial limit of the brachium conjunctivum. Though the ventral limit of this nucleus usually corresponds 
in this region to the roof of the aqueduct, some cells can be seen at the level of the brachium conjunctivum, following the course of the root toward these fiber masses. The main part of the nucleus represents here an almost vertical cell mass, mostly compact, sometimes consisting of cell groups lying quite close to one another. The dorsal limit of the nucleus corresponds to the medioventral border of the nucleus colliculi inferioris. Sometimes, a group of cells of the nucleus of the mesencephalic root of $V$ lies in its dorsal part in a more lateral position, forming a sort of cap over the root fibers of the mesencephalic root of $V$. These cells are located among the internal fibers of the lateral lemniscus. A few cells are found also in a more dorsal situation, either among the cells of the nucleus colliculi inferioris or close to the commissure of this colliculus, following the abovementioned fibers of the lateral lemniscus. These cells lie thus sometimes very near to the median line, ventral to the commissura colliculi inferioris. The greater part of the root fibers of the mesencephalic root of $\mathrm{V}$ are situated lateral to its nucleus. In passing ventralward the root fibers cross the medial part of the brachium conjunctivum. At the beginning of the trochlear decussation, a part of the nucleus of the mesencephalic root of $\mathrm{V}$ lies dorsal to this crossing, the other part ventral to it. Single cells are seen very far dorsally in the caudal part of the colliculus inferior and also among the trochlear fibers (fig. 26). However, the main masses of the nucleus are found ventral to the trochlear nerve, in a small triangular space limited by the trochlear nerve above, by the root fibers of the mesencephalic root of $\mathrm{V}$ on the lateral side, and by the trochlear root on the medial side (fig. 26). Medial to the trochlear root, and also ventral and ventromedial to the nucleus of the mesencephalic root of $\mathrm{V}$, lies the nucleus loci coerulei. Closely lateral and ventrolateral to this nucleus and its root, is situated the brachium conjunctivum, bordered on its medial and medioventral side by the cells of the nucleus loci coerulei. 
In sections passing through the most caudal part of the corpora quadrigemina posteriora, the cells of the nucleus of the mesencephalic root of $V$ are fewer in number and found only ventral to the trochlear nerve. The nucleus loci coerulei lies with its dorsal limit around the dorsolateral angle of the IVth ventricle, a few of its cells being located in the lateral part of the anterior medullary velum, ventral

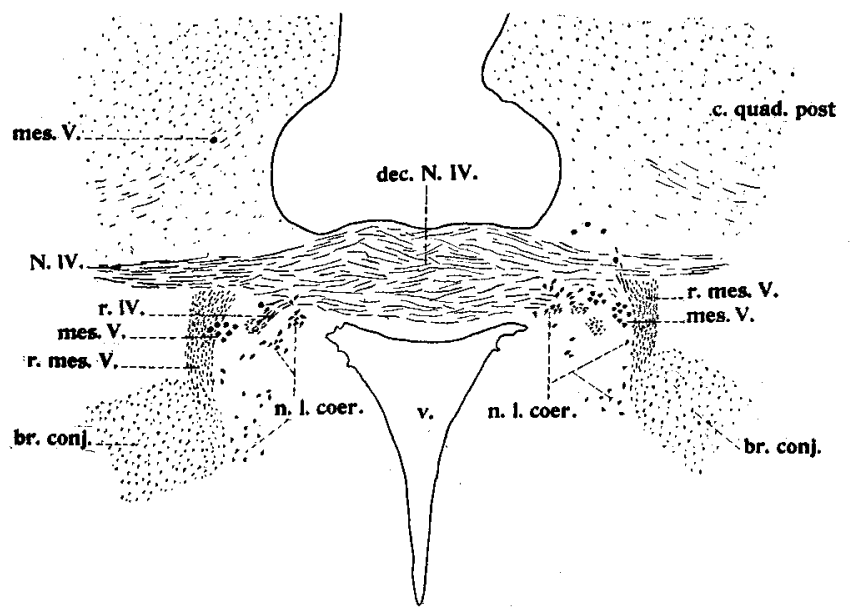

Fig. 26 Cross-section through the level of the trochlear decussation of monkey (Macacus rhesus). Toluidin-blue preparation. $\times 11$. br.conj., brachium conjunctivum; c.quad.post., corpus quadrigeminum posterius; dec.N.IV., decussation of the trochlear nerves; mes.V., cells of the mesencephalic root of V; n.l.coer., nucleus loci coerulei; N.IV., trochlear nerve; r.IV., trochlear root; r.mes. $V$., mesencephalic root of $\mathrm{V} ; v$., ventricle.

to the trochlear crossing. The main cell masses of the nucleus of the mesencephalic root of $V$ lie lateral to the dorsal part of the nucleus loci coerulei. The brachium conjunctivum is seen now closely lateral to the root fibers of the mesencephalic root of $\mathrm{V}$, which latter passes now through the ventral part of the nucleus loci coerulei, dividing this cell mass into a lateral portion, lying ventral to the brachium conjunctivum, and a medial one, lying between the periventricular gray and the root fibers of the mesencephalic root of $V$. Some cells of the nucleus of the mesencephalic 
root of $V$ accompany the root ventralward until the level of the ventral border of the brachium conjunctivum.

In sections caudal to the trochlear decussation the position of the nucleus of the mesencephalic root of $V$ is slightly more ventral. Its dorsal limit is situated a little below the level of the roof of the IVth ventricle, the ventral reaches the level of the ventral border of the brachium conjunctivum. Medial to the cells of the mesencephalic root of $\mathrm{V}$ lies always the nucleus loci coerulei, the dorsal limit of which has a more dorsal position than that of the nucleus of the mesencephalic root of $\mathrm{V}$. Lateral to the latter lies the brachium conjunctivum and, between these two formations, the root fibers of the mesencephalic root of $V$. The nucleus represents still a vertical cell column, composed of small cell groups or of cells lying in a single or double row. Sometimes the column has a slight ventrolateral orientation. The cells in this region are already few in number.

The most caudal part of the nucleus of the mesencephalic root of $V$, just in front of the motor nucleus of $V$, represents a quite compact, round, or irregularly shaped nuclear mass, located lateral and ventrolateral to the nucleus loci coerulei. More dorsally situated cells are here very rare. The ventral part of the nucleus extends sometimes as a single cell row a little farther ventrolateralward in company with the root. The few cells, which are found still at the level of the motor nucleus of $V$, are situated also at the lateral border of the ventral part of the nucleus loci coerulei. The root fibers of the mesencephalic root of $\mathrm{V}$ run in a ventrolateral direction at the level of the motor nucleus of $V$ and pass between the motor and sensory nucleus of $\mathrm{V}$ and the corresponding roots.

The cells of the nucleus of the mesencephalic root of $V$, though very closely intermingled with those of the nucleus intratrigeminalis and especially with those of the nucleus loci coerulei, are very easily distinguishable by their characteristic appearance, which differs from that of the cells of both the other nuclei. In monkey, in our toluidin-blue 
material, the cells of the mesencephalic root of $\mathrm{V}$ appear granular, the Nissl substance being always equally distributed throughout the whole cell body. Only one process is observable in most of the cells of our preparations. This process is sometimes faintly stained with toluidin blue and, occasionally, is divided into two branches. In a very few cases a cell is found with two processes arising from the opposite poles of the cell body. The single cell processes are directed toward the root. In the caudal part of the nucleus some processes are turned dorsalward, others ventralward. The average shorter axis of the cells is $22.4 \mu$, the average longer, $31.6 \mu$. The smallest cells are found also in monkey, mostly in the dorsal part of the nucleus, in the region of the corpora quadrigemina anteriora. The longer axis of the dorsal cells is oriented usually in a dorsoventral direction. The more ventral cells in the frontal part of the nucleus have their longer axes in a transverse plane. The process of such a cell is directed lateralward, but turns ventralward soon, following a hook-like course. The cells in the region of the corpora posteriora are oriented mostly in a dorsoventral direction. The long axis is turned slightly ventrolateralward in those cells of this region, which are located more laterally and dorsally and thus close to the nucleus tuberculi posterioris. In the distal part of the corpora posteriora the orientation of many cells is a transverse one, while in the region of the trochlear decussation and caudal to it the orientation is again a dorsoventral one.

In the monkey, in comparison with the relations found in rat and cat, the proximal limit of the nucleus of the mesencephalic root of $V$ is a slightly more frontal one. In both the rat and cat the proximal limit of the nucleus was observed caudal to that of the posterior commissure, while in monkey this commissure and the nucleus of the mesencephalic root of $\mathrm{V}$ begin frontally at nearly the same level. The caudal limit of the nucleus of the mesencephalic root of $V$ is, in the monkey as in rat and cat, at the level of the frontal portion of the motor nucleus of $V$. However, in both the rat and cat more cells are found at this level than in the monkey. 
The dorsoventral extension of the nucleus of the mesencephalic root of $\mathrm{V}$ in monkey is more suggestive of the relations in cat than of those in the rat, in both cat and monkey cells dorsal to the aqueduct being observed. Furthermore, the small cells are found in monkey, as in cat, chiefly in the dorsal part of the nucleus, in the region of the corpora quadrigemina anteriora. Howevor, a decrease of cells in the region of the corpora posteriora is much more pronounced in cat than in monkey. Also, a difference in the shape of cells in this part of the nucleus is not obvious in the latter. A clustering into groups is more pronounced in monkey than in either cat or rat, and the individual cell groups are much larger in the former.

In monkey the trochlear root lies medial to the nucleus of the mesencephalic root of $V$, in contradistinction to the relations in cat (Hulles, '07). The relation of this nucleus to the nucleus loci coerulei is similar in monkey to that in the cat.

\section{The mesencephalic root of $V$ in man}

In man the cells of the nucleus of the mesencephalic root of $V$ are found throughout the whole longitudinal extension of the midbrain and in the pons to the level of the caudal quarter of the motor nucleus of $V$. The whole frontocaudal extension of the nucleus of the mesencephalic root of $V$ is thus about $25 \mathrm{~mm}$. In the brain studied by us the cells are observed on the right side for a distance of about $24.4 \mathrm{~mm}$. and on the left for a distance of about $26.2 \mathrm{~mm}$. in longitudinal direction, beginning from the region of the posterior commissure. The most frontal cells of the nucleus of the mesencephalic root of $V$ are found about $1.8 \mathrm{~mm}$. in front of the proximal limit of the main oculomotor nucleus. The caudal limit of the nucleus of the mesencephalic root of $\mathrm{V}$ corresponds practically to a level about $1 \mathrm{~mm}$. frontal to the distal limit of the motor nucleus of V. However, sometimes occasional cells can be seen even a little farther caudalward. 
The position of the nucleus of the mesencephalic root of $\mathrm{V}$ in the region of the midbrain corresponds on the whole to the relations in monkey and eat. In man the most frontal cells are few in number, as in the other forms studied. They lie at the inner border of the stratum album profundum. Their situation corresponds, in general, to the level of the dorsal half of the aqueduct. Occasional cells are seen in a more ventral position, but not ventral to the level of the aqueduct. Some cells are observed also dorsal to the aqueduct. These cells are located more medially than the more ventral cells of the nucleus of the mesencephalic root of $V$. However, there are very few cells which lie less than about $2.5 \mathrm{~mm}$. from the midline. Since the most frontal cells are few in number, they do not form any groups and are scattered around the periventricular gray of the aqueduct. They are here more or less strictly limited to the outer border of this gray. In sections passing only a little frontal to the oculomotor nucleus the cells of the nucleus of the mesencephalic root of $\mathrm{V}$ are already more numerous, as is evident from serial-cell counts. At the same time, a clustering of cells into small groups of two or three cells is evident and the cells are less regularly limited to the inner border of the stratum album profundum, being situated now a little deeper in the periventricular gray. As in monkey, the grouping is more pronounced in the ventral part of the nucleus. The dorsal cells, being less numerous, deviate less from the outline of the outer border of the periventricular gray. However, neither the dorsal nor the ventral cells are observed among the fibers of the stratum album profundum. The most dorsal cells lie here also dorsal to the level of the aqueduct and usually not very close to the median line, while the ventral limit of the nucleus corresponds approximately to the middle third of the dorsoventral extension of the aqueduct. According to their situation at the outer border of the periventricular gray, the cells form, as in other mammals, a somewhat curved line around this gray. Due to the greater deviation of the cells of the mesencephalic root of $V$ from 
the strict outline of the periventricular gray, this curved cell line is in man less regular than in other mammals.

In sections passing through the proximal part of the oculomotor nucleus the cell groups become larger, being composed of from two to seven cells, and the cells become still a little more removed from the inner border of the stratum album profundum. The ventral limit of the nucleus of the mesencephalic root of $\mathrm{V}$ is formed by the inner curve of the medioventral portion of the stratum album profundum. It is just dorsal to these fiber masses that the larger groups of cells of the mesencephalic root of $\mathrm{V}$ are located and are here often found deeper in the periventricular gray. These groups lie by the side of the aqueduct, especially at the level of the middle third of its dorsoventral extension. The curved line formed by the scattered dorsal cells is concave ventromedialward toward the aqueduct. It is sometimes continuous with the above-described cell groups at the level of the aqueduct.

Farther caudalward, the cells of the nucleus of the mesencephalic root of $\mathrm{V}$ are also observed in more ventral regions (fig. 27). The main cell masses are located, in general, at the level of the aqueduct, but, occasionally, cells are found now ventral to this level. These ventral cells are in a more medial position than the cells of the middle part of the nucleus, being approximately in the same relation to the median line as the cells which lie dorsal to the aqueduct. The most ventral cells are confined more strictly to the outer border of the periventricular gray. A few cells are found in very close relationship to the oculomotor nucleus (fig. 27, a.), a few of them lying even ventral to this nucleus, between the latter and the fasciculus longitudinalis medialis (fig. 28). The single process of such a cell is directed ventralward. Occasionally, a cell of the nucleus of the mesencephalic root of $\mathrm{V}$ can be seen among the cells of the IIIrd nucleus.

Beginning from a region slightly in front of the IIIrd nucleus, the number of cells of the nucleus of the mesencephalic root of $\mathrm{V}$ is relatively constant (about ten to fifteen cells) 
in each cross-section through the greater part of the corpora quadrigemina anteriora. However, in the caudal third of the corpora anteriora a slight decrease of the number of cells of the nucleus of the mesencephalic root of $\mathrm{V}$ is evident. In the caudal region of the corpora quadrigemina anteriora

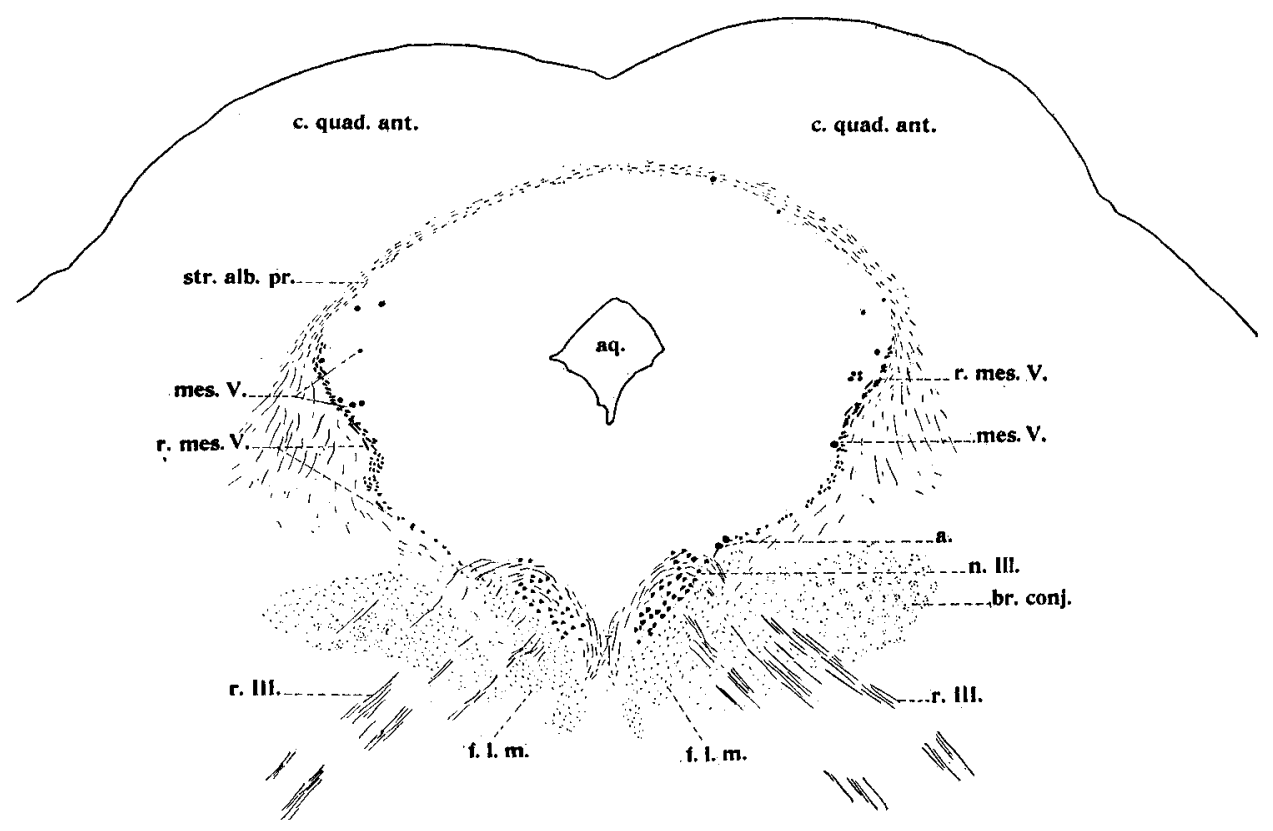

Fig. 27 Cross-seetion through the region of the oculomotor nueleus of man. Chrom-silver preparation. $\times 7 \frac{1}{2}$. a., a cell of the mesencephalic root of $\mathrm{V}$ lying very close to the oculomotor nucleus, the process of this cell is directed toward the root fibers of the third nerve; aq., aqueduct; br.conj., brachium conjunctivum; e.quad.ant., corpus quadrigeminum anterius; f.l.m., fasciculus longitudinalis medialis; mes.V., cells of the mosencephalic root of $\mathrm{V}$; n.III., oculomotor nucleus; r.III., oculomotor root; r.mes.V., mesencephalie root of $\mathrm{V}$; str.alb.pr., stratum album profundum.

and in the corpora posteriora the stratum album profundum is less curved in its ventral part and, therefore, is situated nearly vertically by the side of the aqueduct. The scattered cells of the nucleus of the mesencephalic root of $\mathrm{V}$, or the small groups of these cells, accordingly, are arranged in a vertical line, which line, in the region of the corpora pos- 
teriora, is more strictly confined to the inner border of the stratum album profundum and deviates less deeply into the periventricular gray than in more frontal parts of the nucleus. The position of the whole nucleus is here more ventral, the main nuclear masses lying at the level of the ventral two-thirds of the aqueduct and slightly ventral

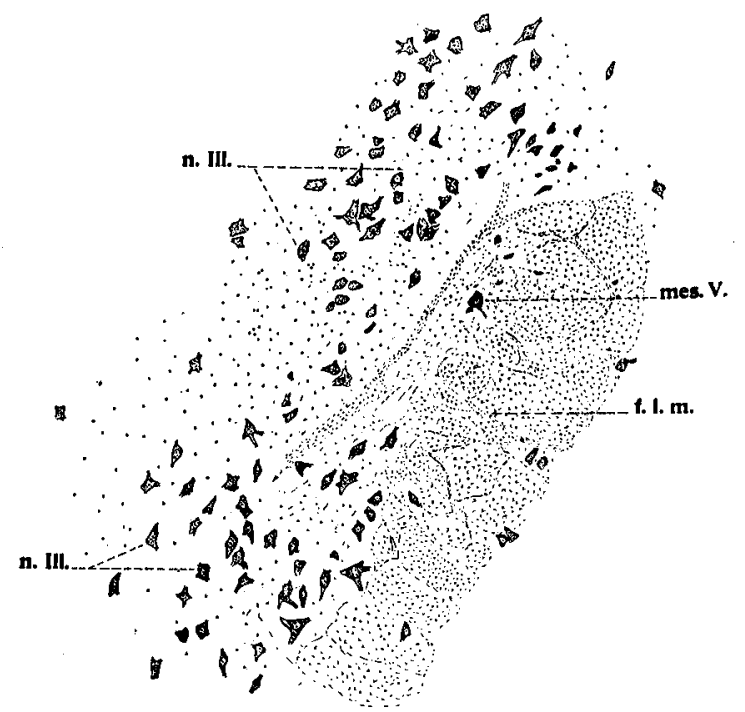

Fig. 28 A cell body of the type of the neurones of the mesencephalie root of $V$, situated dorsal to the medial longitudinal fasciculus and among the cell bodies comprising the oculomotor nueleus. The process of the cell is directed ventralward. Man. Toluidin-blue preparation, $\times 47 \frac{1}{2}$. f.l.m., fasciculus longitudinalis medialis; mes.V., cell of the mesencephalic root of $V$; n.III., oculomotor nucleus.

to the level of the latter. Only in this main part of the nucleus are the cells arranged in small groups. The groups lie above each other in a line parallel to the aqueduct. In addition to this vertical nuclear mass, cells are found also in a more medial and still more ventral position. In sections in which the cells are relatively numerous they form an almost horizontal row, at the outer border of the periventricular gray, the medial limit of this row lying 
but a little more ventrally than the lateral limit. The lateral limit of the cell row is often continuous with the vertical cell masses and both parts of the nucleus together form thus a curve with the concavity turned inward toward the ventrolateral angle of the aqueduct. The most medial of the ventral cells lie very close to the trochlear nucleus. One cell of the nucleus of the mesencephalic root of $\mathrm{V}$ is found even among the cells of the trochlear nucleus (fig. 29). The cells of the horizontal part of the nucleus are less numerous than those of the vertical and usually do not

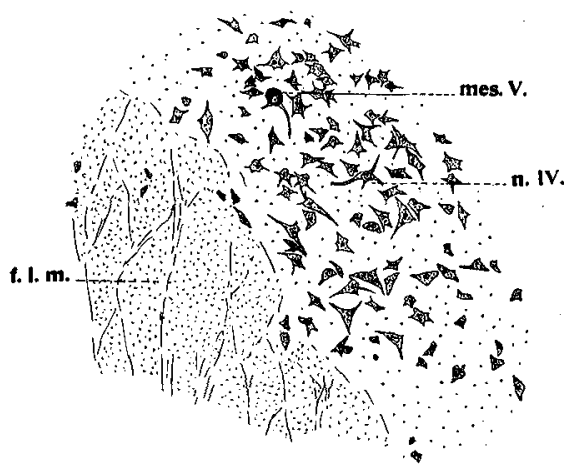

Fig. 29 A cell body of the type of the neurones of the mesencephalic root of $\mathrm{V}$ among the cells of the trochlear nucleus in man. Toluidin-blue preparation. $\times 47 \frac{1}{2}$. f.l.m., fasciculus longitudinalis medialis; mes.V., cell of the mesencephalic root of $\mathrm{V} ; n . I V$., cells of the trochlear nucleus.

form groups. Occasionally, scattered cells can be seen here also dorsal to the aqueduct, sometimes very close to the median line. The dorsal cells are still fewer in number than those of the horizontal ventral part of the nucleus of the mesencephalic root of $V$.

Farther caudalward, in the region of the corpora posteriora, the main nuclear masses of the mesencephalic root of $\mathrm{V}$ are situated still more ventrally. The position of the dorsal half of the nucleus corresponds approximately to the level of the ventral half of the aqueduct, while its lower half is located ventral to the level of the latter. The scattered 
small cell groups lie, as before, above each other in a vertical plane. Cells in a more medial position, close to the trochlear nucleus, occur here also, but are less frequent than in more frontal regions. The same is the case with the cells which are situated dorsal to the aqueduct at the ventral border of the commissura colliculi inferioris. The vertical cell masses of the nucleus of the mesencephalic root of $V$ are limited here, as in the monkey, in their dorsal part at the lateral side by the internal fibers of the lateral lemniscus. Between the cells and these fibers are situated the root fibers of the mesencephalic root of $\mathrm{V}$. However, in monkey a few cells could be seen which, situated lateral to the root fibers of the mesencephalic root of $\mathrm{V}$, were located among the internal fibers of the lateral lemniscus. The long axis of these cells was oriented in the direction of these fibers. In man cells in a similar position are still more rarely seen.

In the distal part of the corpora quadrigemina posteriora, caudal to the trochlear nucleus, the ventral part of the aqueduct stretches out ventralward as a narrow, elongated recess (fig. 30). The aqueduct extends thus farther ventralward than in more frontal regions. The nucleus of the mesencephalic root of $V$, therefore, again lies now with its main nuclear masses at the level of the middle third of the dorsoventral extension of the aqueduct. The dorsal limit of the nucleus corresponds here in general to the ventral border of the nucleus colliculi inferioris, the medial part of which is situated dorsal to the nucleus of the mesencephalic root of $\mathrm{V}$ (fig. 30). Only a very few cells are observed now sometimes dorsal to the aqueduct, at the ventromedial border of the commissura colliculi inferioris. The groups by the side of the aqueduct are larger and situated more closely to each other, so that the nucleus appears on the whole more cormpact. The groups do not lie quite vertically above each other, but some are in a more medial, some in a more lateral position. The pigmented cells of the nucleus loci coerulei begin to appear in this region. They are not numerous yet and are scattered in the periventricular gray medioventral 
to the cells of the mesencephalic root of $\mathrm{V}$. The root fibers of the mesencephalic root of $\mathrm{V}$, lying mostly lateral to its cells of origin, form a bundle which is here slightly curved inwardly and in its dorsal part is in a close contact with the internal fibers of the lateral lemniscus. Both fiber masses diverge ventralward, those of the mesencephalic root of $\mathrm{V}$ maintaining an almost vertical position, while the fibers

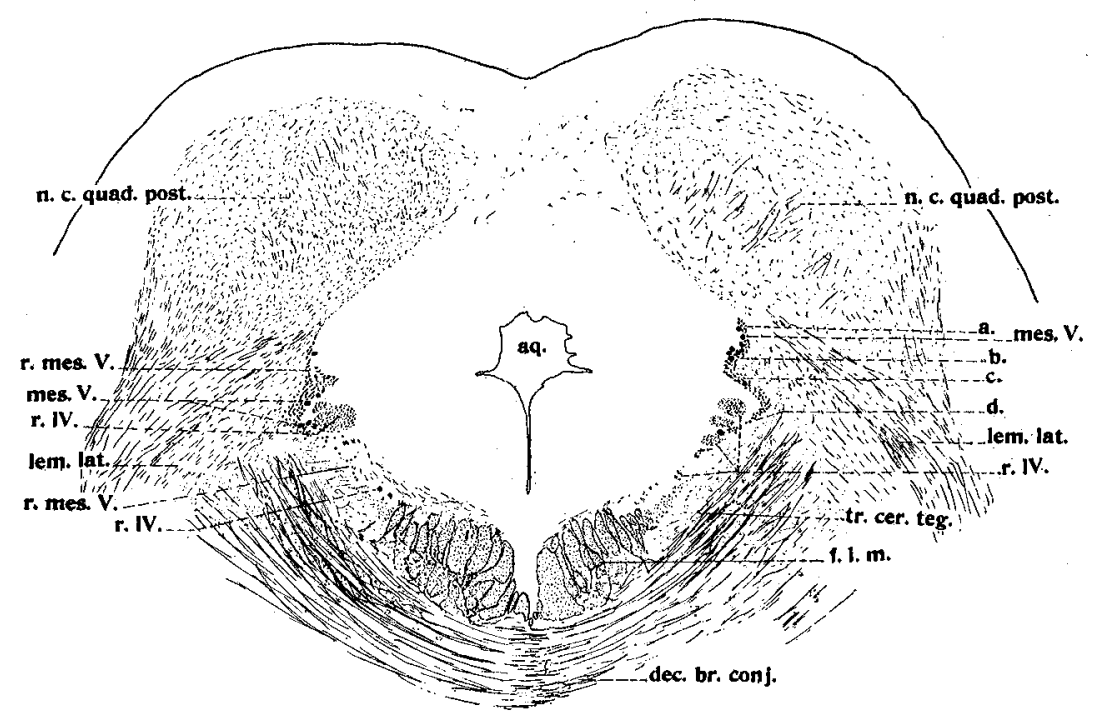

Fig. 30 Cross-section through the region of the corpora quadrigemina posteriora of man, eaudal to the trochlear nucleus. The right side of the figure is slightly farther frontal than the left side. Chrom-silver preparation. $\times 7 \frac{1}{2}$. $a q .$, aqueduct; $a ., b ., c, d .$, portions of the mesencephalie root of $N$ (see description); dec.br.conj., decussatio brachii conjunctivi; f.l.m., fasciculus longitudinalis medialis; lem.lat., lemniscus lateralis; mes.V., cells of the mesencephalic root of $\mathrm{V}$; n.c.quad.post., nucleus corporis quadrigemini posterioris; $r . I V$., trochlear root; r.mes.. ., mesencephalic root of $\mathrm{V}$; tr.cer.teg., tractus cerebellotegmentalis.

of the lateral lemniscus swing lateralward around the ventral border of the nucleus colliculi inferioris in a curve which is concave on the dorsal side. The bundles of the trochlear root lie medial to the ventral part of the nucleus of the mesencephalic root of $V$. They are surrounded by the scat- 
tered cells of the nucleus loci coerulei. Ventral to the root fibers of the mesencephalic root of $\mathrm{V}$, in the most caudal region of the corpora posteriora, lies the lateral part of the brachium conjunctivum, the fibers of which are decussating.

At approximately the same level as the ventral limit of the root fibers of the mesencephalic root of $V$, lies the lateral limit of the medial longitudinal fasciculus. This fasciculus and the root are situated very close to each other and in cross-sections form together a curve concave dorsomedialward. In cross-sections through the most caudal part of the corpora posteriora the nucleus of the mesencephalic root of $\mathrm{V}$ is found in a slightly more dorsal position. The main nuclear masses lie here at the level of the lateral angle of the aqueduct, or of the transition of the aqueduct into the IVth ventricle. They are here less removed from the cavity of the aqueduct than in more frontal regions. A few cells are seen here also dorsal to the level of the aqueduct, being in a slightly more medial position than the other cells. The bundle of root fibers of the mesencephalic root of $\mathrm{V}$ is here more concave medialward; its bend corresponds to the level of the middle third of the aqueduct.

In the region of the trochlear crossing and in the frontal part of the anterior medullary velum, the cells are relatively few in number, numbering about one to ten cells in each cross-section, on either side. The greater part of them lie lateral to the trochlear root. However, some cells are observed dorsal to the fiber bundles of the IVth root at this level where these root fibers run medialward, dorsal to the aqueduct. These cells are located between the trochlear root and the crossed IVth nerve. In man the cells of the mesencephalic root of $V$ are found less frequently in this position than in monkey. 'The length of the 'crescent-shaped' (Meynert, '67; Henle, '79) bundle of root fibers of the mesencephalic root of $\mathrm{V}$ is here about $1.3 \mathrm{~mm}$., its greatest breadth about $0.25 \mathrm{~mm}$. The narrowing ventral end of the root disappears into the cell masses of the nucleus loci coerulei. This nucleus lies ventromedial to the nucleus of the mesencephalic 
root of $V$, its main masses being situated medial to the root fibers of the mesencephalic root of $V$. This part of the brachium conjunctivum, the fibers of which are cut transversely in cross-sections, lies now lateral to the root fibers of the mesencephalic root of $\mathrm{V}$. Those fibers of the brachium conjunetivum which are seen in this region to run to their decussation are, as before, ventral to the mesencephalic root of $\mathrm{V}$ and to the medial longitudinal fasciculus.

Throughout the whole region of the anterior medullary velum the number of cells of the nucleus of the mesencephalic root of $\mathrm{V}$ remains relatively small. The dorsal limit of the root corresponds to the level of the lateral angle of the IVth ventricle. Its dorsoventral extension is here also approximately $1.3 \mathrm{~mm}$. On its medial side it is bordered by its cells of origin. Only occasional cells are found lateral to the root. The most ventral cells of this nucleus are often intermingled with the cells of the nucleus loci coerulei, which latter cells are located also among the root fibers. A part of the nucleus loci coerulei lies lateral and ventrolateral to the ventral third of the mesencephalic root of $V$, while its greater part is situated medial to the ventral third of the root. The greater number of cells of the nucleus of the mesencephalic root of $\mathrm{V}$ are found medial to the middle third of the root; just above the nucleus loci coerulei. In the frontal region of the anterior medullary velum, immediately caudal to the trochlear decussation, a few cells of this nucleus are observed still in the anterior medullary velum, just above the lateral angle of the IVth ventricle. In more distal regions of the anterior medullary velum, no cells can be observed in this velum. The shape of the mesencephalic root of $\mathrm{V}$ undergoes in the caudal region of the anterior medullary velum some slight modifications : its medial border becomes more nearly straight and lies nearly vertical, the lateral border remains convex on the outer side, while in more frontal regions both medial and lateral borders of the root were convex on the outer side. However, farther caudalward, the root again presents in some sections a crescentic form with the concavity directed medialward. 
In sections passing through the lingula cerebelli the bundle of root fibers of the mesencephalic root of $V$ makes a more abrupt bend medialward with its ventral portion, which lies in the nucleus loci coerulei. Therefore, a vertical and a horizontal part, joined together almost at a right angle, can be distinguished in the cross-cut root. In this region the brachium conjunctivum lies lateral and dorsolateral to the nucleus and root fibers of the mesencephalic root of $V$. The cells are here still less numerous, but now, in addition to the cells lying lateral to the IVth ventricle, occasional cells can be seen also in the roof of the latter, just above its dorsolateral angle in a position similar to that occupied by some cells in the most frontal region of the anterior medullary velum. The cells above the dorsolateral angle of the IVth ventricle lie ventral to the fibers of the brachium conjunctivum.

Farther caudalward, the nucleus loci coerulei, representing in more frontal sections a more or less round nuclear mass pierced at its lateral side by the root fibers of the mesencephalic root of $V$, flattens out from above downward and stretches out from the medial limit of the root fibers of the mesencephalic root of $\mathrm{V}$, medialward below the floor of the IVth ventricle. A part of this nuclear mass lies ventral to the horizontal part of the bundle of root fibers of the mesencephalic root of V, another dorsal to it (fig. 31). The main masses of the nucleus loci coerulei appear somewhat as a continuation of the horizontal part of the mesencephalic root of $\mathrm{V}$ medialward (fig. 31). The number and arrangement of the cells of the mesencephalic root of $V$ are here approximately the same as before. Being few in number, the cells do not form large groups.

At the level of the motor nucleus of $V$, the number of the cells of the nucleus of the mesencephalic root of $V$ has increased so as to number about ten to twenty cells, on either side in each cross-section. The increase begins a little in front of this level, where also larger cell clusters make their appearance. The cells are most numerous in the region of 
the frontal third of the motor nucleus of $\mathrm{V}$. The cell groups have often a shape of circles or half-circles (fig. 32) around a fiber bundle of the root. Often, the center of the group is very rich in glia nuclei and sometimes also, small nerve cells of the character of the sensory cells of $V$ can be observed in the center of the group or in its close vicinity. The groups lie by the side of the IVth ventricle, at a distance of about 0.4 to $1 \mathrm{~mm}$. from the ventricular cavity. The largest groups

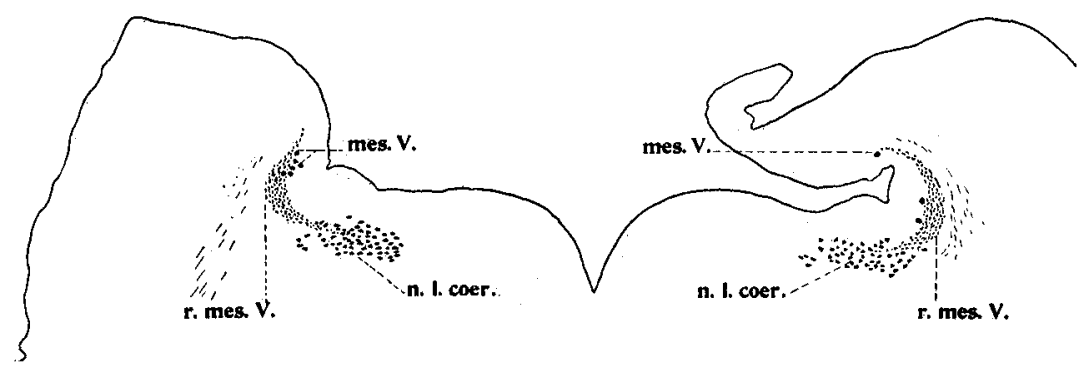

31

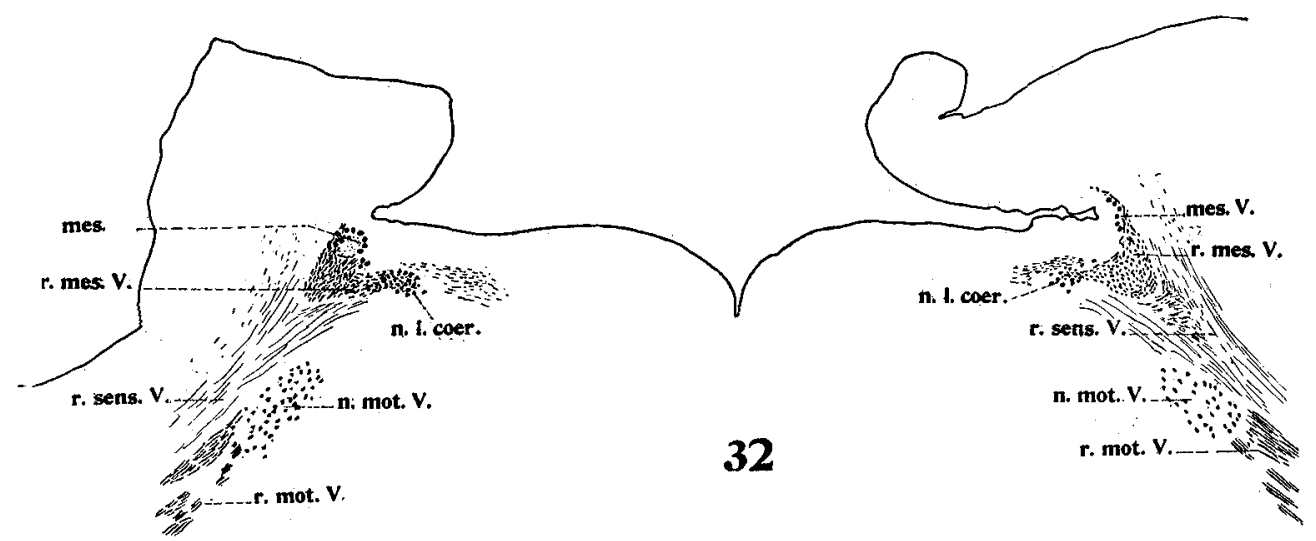

Fig. 31 Cross-section through the frontal portion of the pons in man, showing the relation of the mesencephalic root of $V$ to the nucleus loci coerulei. Chrom-silver preparation. $\times 7 \frac{1}{2}$. mes. $V$., cells of the mesencephalic root of $\mathrm{V}$; n.l.coer, nucleus loci coerulei; r.mes.V., root of mesencephalic $V$.

Fig. 32 Cross-section through the region of the frontal portion of the motor nucleus of $\mathrm{V}$ in man. The right side of the figure is slightly farther frontal than the left. Chrom-silver preparation. $\times 7 \frac{1}{2}$. mes.V., cells of the mesencephalic root of $\mathrm{V}$; n.l.coer., nucleus loci coerulei; n.mot.V., motor nucleus of $\mathrm{V}$; r.mes.. ., mesencephalic root of $V ; r . m o t . V$. , motor root of $V ; r . s e n s . V .$, sensory root of $V$. 
are located at the level of the ventral angle of the lateral recess of the IVth ventricle. Smaller groups and scattered cells are observed very often at a more ventral level. These cells are situated sometimes more medially, just above the motor nucleus of $V$. Sometimes they are found between the motor and sensory nuclei of $V$, among the root fibers of these nuclei and among those of the mesencephalic root of $V$. Cells in such a position are more frequent in the most caudal part of the nucleus of the mesencephalic root of $V$. The orientation of the long axis of these cells corresponds to that of the root fibers, which are directed ventrolateralward. Sometimes the cells of the mesencephalic root of $\mathrm{V}$, between the motor and sensory nuclei of $V$, are arranged into rows of four or five cells, the cells lying close to each other, the orientation of the row corresponding to that of the long axis of the cells. In addition to these, some cells of the mesencephalic root of $\mathrm{V}$ are observed dorsal to the lateral recess of the IVth ventricle. These cells are nearer to the ventricular cavity and form occasionally a row situated around the dorsal angle of said recess of the IVth ventricle, and lying obliquely in a dorsomedial plane. The long axis of these cells is oriented in the same plane. Of more frequent occurrence than the presence of cells situated dorsal to the lateral recess of the IVth ventricle, are cells by the side of this recess. They are either scattered or arranged into almost vertical rows, while the cell clusters at the ventral angle of the lateral recess of the IVth ventricle, where the largest groups are observed, are of a more rounded shape.

Approximately at the level of the middle third of the longitudinal extension of the motor nucleus of $V$, the cells of the mesencephalic root of $V$ become quite abruptly less numerous and disappear almost entirely at the beginning of the caudal third of the region of the motor nucleus of $V$. Only occasional cells are observed in a very few sections passing through the caudal third of this nucleus. However, they are not found at all in sections passing through the most caudal part of it. 
The appearance of the cells of the nucleus of the mesencephalic root of $\mathrm{V}$ (fig. $34, f ., g ., h ., i$, and fig. $35, l$. ) corresponds to that described for lower mammals. In man, in the frontal portion of the nucleus, there can also be observed smaller cells of a diameter of about 18 to $20 \mu$, which are located, as in cat and monkey, chiefly in the dorsal part of the nucleus, dorsal to the level of the aqueduct. On the average, the cells of the mesencephalic root of $V$ in man are

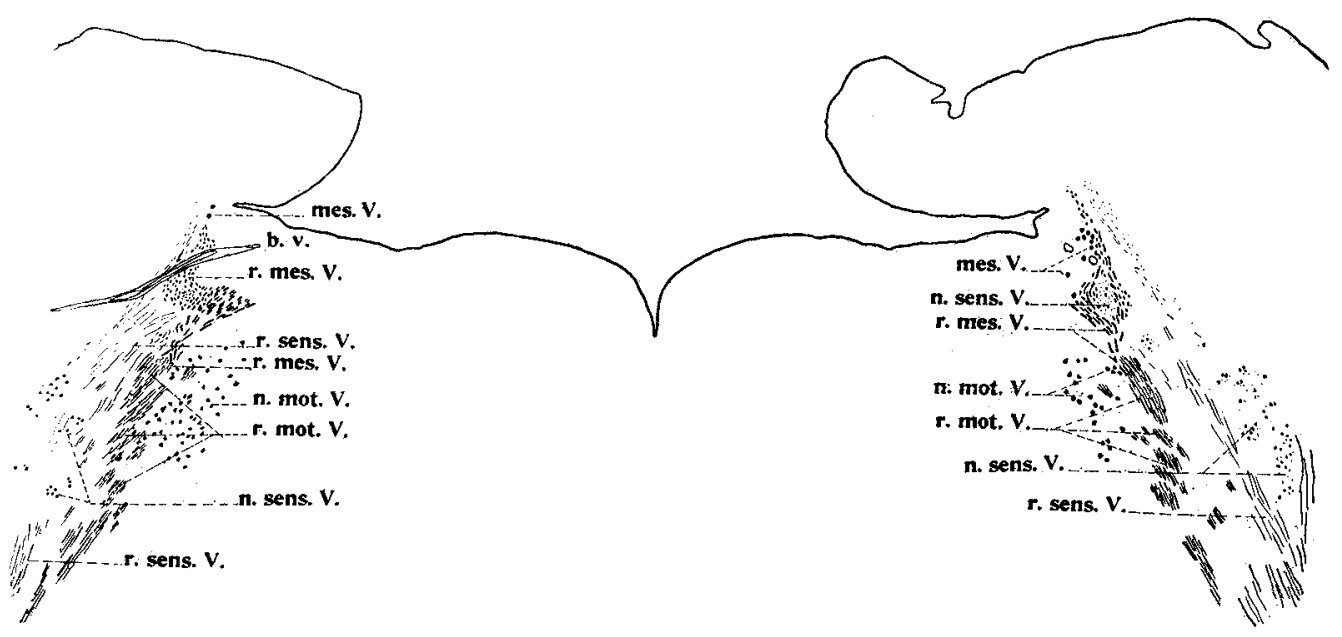

Fig. 33 Cross-section through the region of the motor and sensory nuelei of $\mathrm{V}$ in man, showing the intermingling of the fibers of the mesencephalie root of $\mathrm{V}$ with the fibers of the motor root of $\mathrm{V}$. Chrom-silver preparation. $\times 7 \frac{1}{2}$. $b . v$., blood vessels; mes.V., cells of the mesencephalic root of $\mathrm{V}$; n.mot.V., motor nueleus of $\mathrm{V}$; n.sens. $V$., sensory nueleus of $\mathrm{V}$; r.mes.V., mesencephalic root of $\mathrm{V}$; r.mot.V., motor root of $\mathrm{V}$; r.sens.V., sensory root of $\mathrm{V}$.

about $35 \mu$ in length and $28 \mu$ in breadth. The largest cells in our material are about $30 \mu$ in the short axis and about $50 \mu$ in the long. In toluidin-blue preparations mostly one process to a cell can be seen. However, cells with two processes (fig. $34, f ., h$.) occur occasionally. These latter are observed chiefly in the caudal portion of the nucleus. In cells lying at the level or dorsal to the dorsal angle of the lateral recess of the IVth ventricle the one process is directed dorsomedialward, the other ventrolateralward. One of these proc- 
esses is usually thicker and more stained than the other. In the cells lying between the motor and sensory nuclei of $V$, the single process is easily seen to run directly ventrolateralward, which accords with the direction of the root fibers of the nuclei of $V$. In bipolar cells, found occasionally also between the nuclei of $\mathrm{V}$, the more deeply stained process runs ventrolateralward, the other dorsomedialward. In the latter process an axon hillock is sometimes quite clearly seen. Occasionally, the less stained process is first directed medialward and then bends ventralward toward the motor nucleus of $\mathrm{V}$; the other process is first directed lateralward, but later also curves ventralward. Very rarely, a cell can be found in our toluidin-blue material which is provided with two or three processes arising from one pole of the cell body and directed ventrolateralward, while from the opposite pole a less stained process emanates (fig. 34, g.).

In man the cells of the nucleus of the mesencephalic root of $\mathrm{V}$ are, in general, easily distinguishable from the polygonal cells of the nucleus loci coerulei, even when intermingled with the latter. The cells of the nucleus loci coerulei in man are heavily pigmented, in contradistinction to these cells in lower mammals (S. Kure, '99; Kohnstamm and Quensel, '08). In other respects they are similar in man to the cells of the nucleus loci coerulei in other animals. According to S. Kure ('99), in man the cells of the nucleus of the mesencephalic root of $V$ contain but a small quantity of pigment in the form of small granules on the border of the cell body. In our material this pigment is seen only in a few of the cells of the mesencephalic root of V. According to Obersteiner ('01), the whole cell body is sometimes studded with a fine, yellow pigment, which is darkly stained in Weigert and Marchi preparations.

In chrom-silver preparations in most cells of the nucleus of the mesencephalic root of $\mathrm{V}$ only one process can be shown. This process is usually very darkly impregnated and in our material is either a little enlarged at its point of emergence from the cell body (Bickel, '02) or projects abruptly from it, 
"like the straw from a soap-bubble" (Meynert, '72). In silver preparations cells with two or more processes are seen more frequently than in toluidin-blue material. In these cells the one process is thick and almost black-it resembles

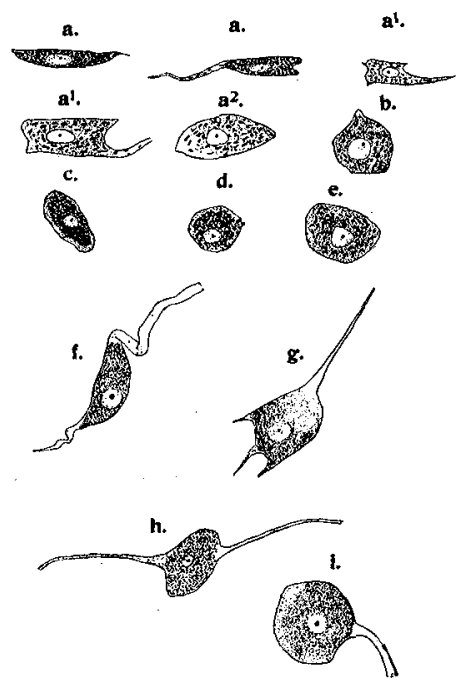

Fig. 34 Cell types of the nucleus of the mesencephalic root of $\mathrm{V}$ in different animals. Camera-lueida drawings. Toluidin-blue preparations. $\times 182 . \quad a$, dark, spindle-shaped medial cells in duck; $a^{1}$., pale, polygonal medial cells in duck; $a^{2}$., oval medial cell in duck; $b$., lateral cell in duck; $c$., cell from the region of the corpora quadrigemina posteriora of cat; $a$., small dorsal cell from the region of the corpora quadrigemina anteriora of cat; e., large ventral cell from the same region as cell $a_{.} ; f_{.}$, cell from the region of the pons, among the fibers of the cerebellar peduncle of man, two processes seen; $g$., cell from the region between the sensory and motor nuclei of $\mathrm{V}$ in man-three short, stained processes, apparently dendrites, turned ventrolateralward, one pale proeess directed dorsomedialward; $h$., a cell from the region just dorsal to the motor nucleus of $\mathrm{V}$ in man-one pale process is directed dorsomedialward, the stained one is direeted ventrolateralward; $i$, an apparently unipolar cell from the region of the midbrain in man.

the above described process in a unipolar cell-and enters the root. The other process, arising for the most part from the opposite pole of the cell body, is usually less heavily impregnated and more slender. They usually arise abruptly from the cell body. Sometimes, the thick process runs 
directly into the root, while in other cases it arises from the pole of the cell opposite to the root and then bends into a loop around the cell body in order to join the root fibers. In some cells which have a kidney- or erescent-shape the two processes, the thick and the thin, run for a short distance parallel to each other. They arise from the horns of the crescent (fig. 35, l.). The slender processes are often seen to divide into still more slender branches.

Some references to the position of the root fibers of the mesencephalic root of $V$ and of its relations to the surrounding formations, as far as this can be seen in toluidin-blue preparations, have already been made during the description of the nucleus. A more detailed description of the course of the root fibers as shown in our silver material may now be presented.

In cross-sections through the frontal region of the midbrain the bundle of root fibers of the mesencephalic root of $\mathrm{V}$ in its dorsal part is in the form of a curve, with the concave side toward the aqueduct. The fibers in this dorsal region are of variable length and are cut mostly longitudinally in cross-sections. The direction of the fibers in the upper part of the curve is ventralward and slightly lateralward, in the lower part ventromedialward. In this latter part some fibers are cut transversely. The ventral part of the curve is situated almost horizontally, however, its lateral portion being more dorsal in position than the medial. The latter bends then quite sharply ventralward. The root becomes thus concave ventrolateralward in this region. These fibers here are cut for the most part transversely in cross-sections. However, some of them turn into a longitudinal direction, but only in the most ventral part of the root, at the level of the IIIrd nucleus. It is possible that some of these fibers, instead of turning caudalward, join the fibers of the oculomotor root, since a cell of the nucleus of the mesencephalie root of $V$, near the oculomotor nucleus, has been seen to give its process toward the fiber bundles arising from this nucleus (fig. 27, a.). This portion of the root, which extends medial- 
ward from the inward-turned curve, is, as described above, placed more nearly horizontally only in the most frontal part of the root. Farther caudalward, it is directed more noticeably ventralward and only slightly medialward (fig. 27). The root is largest in sections passing through the

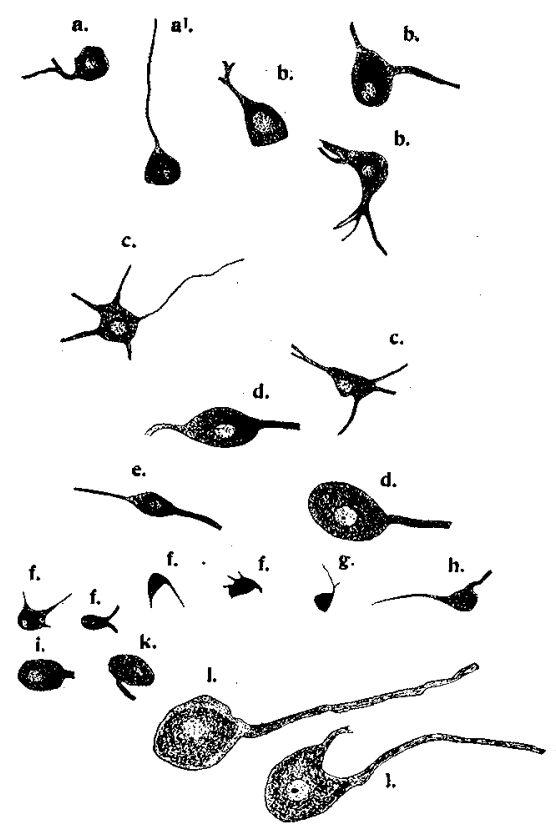

Fig. 35 Cell types of the nucleus of the mesencephalic root of $\mathrm{V}$ in different animals. Camera-lucida drawings. Chrom-silver preparations. $\times 182 . \quad a ., a^{\prime}$., cells in frog; $b$., lateral cells in turtle; $c$., medial cells in turtle; $d$., lateral cells in dove; $e$, intermediate cell in dove; $f$., cells of a mouse embryo near term; $g$, cell of a rabbit embryo of $3 \mathrm{~cm}$; $h$., cell of a rabbit embryo one week before birth; $i$, cell of a rabbit one day after birth; $k$., cell of an adult mouse; $l$., cells of an adult man.

oculomotor nucleus in its ventrolateralward concave portion. The ventral limit of this latter curve bends again medialward, narrowing considerably in this direction, so that only a very few transversely cut bundles are seen close to the medial longitudinal fasciculus (fig. 27). The whole root is situated at the outer border of the periventricular gray of the aque- 
duct, lateral to its cells of origin. The bend medialward in the upper curve of the root corresponds to the level of the middle of the dorsoventral extension of the aqueduct.

In the caudal part of the corpora quadrigemina anteriora, in sections where already the nucleus colliculi inferioris begins to appear, the dorsal limit of the bundle of root fibers of the mesencephalic root of $\mathrm{V}$ corresponds to the middle of the aqueduct. The ventral limit is in a close relation to the medial longitudinal fasciculus, a few fibers of the mesencephalic root of $\mathrm{V}$, the most medial and ventral ones, lying dorsal to the most lateral part of this fasciculus. In the mesencephalic root of $\mathrm{V}$ a dorsal or almost vertical portion and a ventral part can be distinguished at this level. The dorsal part shows a slight coneavity lateralward, the ventral shows a slight coneavity dorsomedialward. Both parts form together a nearly right angle open toward the median line. The ventral part is situated obliquely, its lateral limit lying at a more dorsal level than the medial. The main fiber masses of the mesencephalic root of $V$ are contained in the larger vertical part. Almost all fibers of the root run here in a longitudinal direction.

At the level of exit of the trochlear root from its nucleus, the position and shape of the bundle of the root fibers of the mesencephalic root of $\mathrm{V}$ remains unchanged. In the ventral part of the mesencephalic root of $\mathrm{V}$ appear more fibers running for a short distance in ventromedial direction. The bundles of the trochlear root lie closely medial to this part of the mesencephalic root of $V$. The former are oriented in the same plane and appear of approximately the same length in cross-sections, as some of the fiber bundles of the mesencephalic root of $V$. However, the trochlear fiber bundles are larger and the individual fibers are more slender than those of the fiber bundles of the mesencephalic root of $V$.

Farther caudalward, the root fibers of the mesencephalic root of $\mathrm{V}$ at the level of the ventral third of the aqueduct form a vertical band, slightly curved laterally. At the level of the ventral limit of the aqueduct, this band makes a quite 
abrupt bend lateralward and then again medialward, forming thus a small curve with the concavity medialward. The ventral arm of this small curve then turns ventromedialward toward the trochlear root and enters into a very close relation with this latter and with the medial longitudinal fasciculus. Here, the root fibers of the mesencephalic root of $\mathrm{V}$ run mostly in a longitudinal direction. Only a few fibers run ventralward in the dorsal part of the root and ventromedialward in the ventral portion. In still a little more caudal sections the trochlear bundles are seen in a more dorsal situation. They lie then dorsomedially, close to the oblique, ventral part of the mesencephalic root of $\mathrm{V}$, which is oriented in the same plane as the trochlear root. The fibers of both roots lie so close to each other that an intermingling. might seem to take place. The trochlear fibers are cut, however, longitudinally, while those of the mesencephalic root of $\mathrm{V}$ are cut for the most part transversely. Also, the number of fibers of the mesencephalic root of $V$, crossed in this way by the trochlear fibers, is not great. The main fiber masses of the former root are located in the dorsal part of this root, especially in the region of the small curve of it.

In more caudal sections the ventral arm of the small curve in the bundle of root fibers of the mesencephalic root of $\mathrm{V}$ has increased in bulk. This portion takes now a somewhat triangular shape. It lies a little dorsal and lateral to the trochlear bundles, a narrow band stretching out from the triangular fiber mass ventromedialward, so that the few most ventral bundles of the mesencephalic root of $\mathrm{V}$ lie, as before, closely lateral to the trochlear root. The vertical dorsal part of the root becomes narrower and straightens out more and more, so that its lateral bend, which formed the upper arm of the small curve, disappears at last. The dorsal part of the root represents thus a narrow band (enlarging a little ventralward), the ventral end of which lies slightly more laterally than does the dorsal and thus makes an abrupt turn medialward into the above-described triangular fiber mass of the ventral portion. The whole root in this region can 
be described as formed of two arms, a dorsal one and a ventral one, joined together at a nearly right angle with the opening toward the median line: The dorsal is directed from the point of junction dorsomedialward, the ventral ventromedialward. The latter represents the base for the triangular fiber masses, the apex of which looks dorsomedialward. The majority of the fibers of the mesencephalic root of $\mathrm{V}$ run here in longitudinal direction, while the trochlear fibers; which lie closely medial to the ventral bundles of the ventral arm of the mesencephalic root of $\mathrm{V}$, are directed dorsolateralward. Slightly more caudalward, the trochlear root is situated dorsal and dorsomedial to the ventral bundles of the mesencephalic root of $\mathrm{V}$, but ventral to the level of the triangular fiber mass.

Farther caudalward, the mesencephalic root of $\mathrm{V}$ has a form of a zigzag in cross-sections, lying by the side of the aqueduct at the outer border of the periventricular gray (fig. 30). Four short arms (fig. 30, right side, a., b., c., d.) can be distinguished in this zigzag. The first or upper, the shortest one (fig. 30, a.), has its dorsal limit at the level of the ventral border of the nucleus colliculi inferioris and lies closely medial to the internal fibers of the lateral lemniscus. It is directed ventrolateralward. The second and third arms (fig. $30, b ., c$.) lie respectively in a ventromedial and a ventrolateral plane, and the fourth (fig. 30 , d.) again in a ventromedial plane. All arms join at smooth right angles. The most fiber masses are contained in the two middle arms. The first arm is the less rich in fibers. In the medialward open angle between the two lower arms lies the trochlear root (fig. 30). In the beginning of the zigzag its fibers are almost all cut transversely in cross-sections, but caudalward, some longitudinally cut fibers begin to appear in the two middle arms of the zigzag. They probably represent the ventralward descending fibers of the upper arm, since this latter decreases caudalward more and more. In still slightly more caudal sections the mesencephalic root of $V$ is formed by only two arms, which correspond to the two lower arms of 
the 'zigzag' (c., d.) in a more frontal region. The dorsal limit of the ventrally directed upper remaining arm corresponds to the level of the small lateral recess of the aqueduct. The ventral limit of the ventromedially directed lower remaining arm comes into a contact with the lateral fibers of the medial longitudinal fasciculus. The lower arm is the narrower one. It narrows still more medialward as it bends quite sharply ventralward toward the lateral limit of the medial longitudinal fasciculus. Along the bend, in the lower arm of the mesencephalic root of $V$, some bundles of the trochlear root run dorsalward and turn lateralward around the bend. However, the main part of the IVth root is seen in the angle formed by the junctions of the two remaining arms of the mesencephalic root of $\mathrm{V}$, medial to the upper of these.

In the most caudal part of the corpora quadrigemina posteriora the upper remaining arm of the bundle of root fibers of the mesencephalic root of $V$ becomes longer, as the fibers arising from the dorsal cells in this region do not descend ventralward to any extent, but turn at once caudalward at the dorsal part of the root. This arm of the root is situated now dorsolateral to the IVth root. It is narrow in its dorsal part, but enlarges toward its junction with the lowermost arm. This latter is directed ventromedialward and is much narrower than the former arm. At the level of the trochlear decussation, the uppermost arm of the two, which contains the majority of the fibers of the mesencephalie root of V, takes on its characteristic 'crescent-shape' (Henle, Meynert, Forel, Probst). The dorsal limit of the crescent lies in the angle between the trochlear nerve and the uncrossed trochlear root, ventral to the former and lateral to the latter. From the ventral limit of the crescent the horizontal lowermost arm of the mesencephalic root of $\mathrm{V}$ stretches medialward. It bends, as before, sharply ventralward, but is composed only of a relatively few fibers. All fibers of the mesencephalic root of $\mathrm{V}$ have here a longitudinal direction. 
Caudal to the trochlear decussation, the mesencephalic root of $V$ has the form of a segment of a circle, the lateral border being convex and situated here medial to the ventral limit of the main fiber masses. These bundles lie in a row which runs medialward and then bends ventralward.

In the region of the pons the mesencephalic root of $\mathrm{V}$ again assumes the form of a crescent, the concavity of which is turned medialward (fig. 31). The dorsal limit of the crescent swings slightly medialward above the dorsal angle of the lateral recess of the IVth ventriele, while its ventral limit enters the cell masses of the nucleus loci coerulei (fig. 31). Immediately lateral to the mesencephalic root of $\mathrm{V}$, lies the cerebellotegmental tract.

Farther caudalward in the region of the pons the upper portion of the mesencephalic root of $\mathrm{V}$ is smaller, its fibers beginning to descend ventralward to the ventral part of the root, which becomes larger. The upper limit of the root stretches out only as a narrow strip directed dorsomedialward. The lower limit of the root is directed, as before, medialward into the nucleus loci coerulei. In cross-sections slightly frontal to the motor nucleus of $V$ the fibers more and more appear cut longitudinally. Those of the upper part of the root run ventralward, those of the lower, ventrolateralward, and those in the nucleus loci coerulei course transversely. However, many fibers still run in a longitudinal direction.

In the region of the motor nucleus of $V$, the fiber bundle of the mesencephalic root of $\mathrm{V}$ assumes a somewhat triangular shape (fig. 32). The slightly concave base of this triangle faces the ventrolateral recess of the IVth ventricle, being directed dorsomedialward. One angle of this triangle, the most rounded one, is directed ventrolateralward, one angle is dorsalward and one medialward, the latter angle being composed of fibers situated in the nucleus loci coerulei. More caudalward, the fibers begin to turn more and more ventrolateralward from their longitudinal direction. The longitudinal direction is maintained longest by the fibers 
which lie in the position in which, in more frontal sections, the nucleus loci coerulei was situated. Soon the ventral rounded angle of the root elongates also. The mesencephalic root of $\mathrm{V}$ lies close to the motor nucleus of $\mathrm{V}$, swinging ventrolateralward around the dorsolateral border of the latter (fig. 33).

Having swung around the motor nucleus of $\mathrm{V}$, the fibers of the mesencephalic root of $\mathrm{V}$ lie lateral to the bundles of the motor root of $\mathrm{V}$, but some of the former fiber bundles curve medialward across the fibers of the motor root of $\mathrm{V}$ (fig. 33). They lie thus medial to the dorsally originating motor fibers of $\mathrm{V}$ and lateral to the more ventrally originating fibers. The fibers of the mesencephalic root of $V$ are seen thus to join the motor root of $\mathrm{V}$, inside the brain, intermingling closely with its fibers. Occasionally, some small nuclear groups of the sensory nucleus of $\mathrm{V}$ can be seen on the path of the bundles of fibers of the mesencephalic root of $\mathrm{V}$. The latter swing around these cell clusters without intermingling with their fibers.

The most caudal of the root fibers of the mesencephalic root of $\mathrm{V}$ turn ventralward between the sensory and motor roots of $V$. The possibility that these fibers join the sensory root of $V$ cannot be eliminated entirely, since certain of them are very closely related to this root and run in the same direction. However, such a close intermingling with the sensory fibers of $\mathrm{V}$ as is seen with the motor fibers of $\mathrm{V}$ does not take place, and at least the great majority of the root fibers of the mesencephalic root of $\mathrm{V}$ seem to leave the brain with the motor root of $V$.

\section{DISCUSSION}

1. Position and arrangement of cells of the mesencephalic root of $V$. The studies of P. Ramón ('04) and van Valkenburg ('11) have shown that the nucleus of the mesencephalic root of $\mathrm{V}$ is confined in submammalian forms to the region of the optic tectum. Our observations are in accord with the statements of these authors, since the cells of the mesen- 
cephalic root of $\mathrm{V}$ are never found in our submammalian material caudal to the level of the trochlear decussation. In teleosts and the frog the nucleus is located in the frontal part of the tectum, in Necturus (Johnston, '09) and in the reptiles and birds studied by us throughout the whole length of the tectum. In our reptile and bird material the cells of the mesencephalic root of $\mathrm{V}$, in general, are most numerous at the level of the oculomotor nucleus. According to van Valkenburg ('11) and Kappers ('20), in snakes the cells are concentrated chiefly in the caudal portion of the tectum. In mammals the nucleus of the mesencephalic root of $\mathrm{V}$ extends caudalward into the region of the pons and often more ventralward than in lower forms. However, this statement does not apply to Monotremata, in which the situation of the nucleus of the mesencephalic root of $\mathrm{V}$ is similar to that in submammals, and to Marsupialia, where only single cells are found in a more caudal position (van Valkenburg). In the rodents, carnivores, and primates studied by us the nucleus of the mesencephalic root of $V$ extends from the region of the posterior commissure to the level of the motor nucleus of $V$. The cells are especially far caudal in rabbit, rat, mouse, and man. In rabbit and man, cells are found even between the motor and sensory roots of $V$, following the course of their root fibers. This caudal position is not so pronounced in monkey and cat. Not only in rodents, carnivores, and man is the caudal portion of the nucleus well developed but also, according to van Valkenburg, in insectivores. The latter author and.P. Ramón consider the tectal position of the nucleus as the primitive one and its distal extension as a manifestation of a higher stage of development. Van Valkenburg explains the caudal position of the cells of the mesencephalic root of $\mathrm{V}$ in higher mammals as due to neurobiotactic influences comparable to the phylogenetical behavior of the motor nuclei as described by Kappers ('10). This neurobiotactic migration of cells is carried out toward the sources of their stimuli and is shown. according to van Valkenburg, through the fact that the cells 
of the mesencephalic root of $V$ are oriented in the region of the pons in a frontocaudal direction, while the orientation of the long axes of the more rostral cells is dorsoventral. Our observations seem to strengthen these suggestions. The cells of the mesencephalic root of $V$ lie very often along the course of their root fibers with their long axes oriented in the same plane as the latter. However, this is not invariably the case. The orientation of the long axes of cells in a plane different to the course of the main fiber bundles is explicable by the destination of their central processes or collateral branches of the main process, which conditions may often be the determining factor for the deviation of the main process from its direct course. This deviation is very evident in sagittal sections of our rabbit material, where it has been considered in connection with the cerebellar fibers of the mesencephalic root of $V$. The migration of the cells of the mesencephalic root of $V$ proceeds sometimes very far distalward, as is observed in one of our rabbit embryos, where the cells are located at the exit of the trigeminal roots. It is probable that this migration is carried out even along the root fibers outside the brain, as the findings of Allen ('25) seem to suggest. The influence of the direction of the central as well as the peripheral processes of the cells of the mesencephalic root of $\mathrm{V}$ on their distribution and on the shape of the nucleus within the brain is very evident in our sagittal series of rat, mouse, and, especially, rabbit material. In some of these sections the nucleus appears as if spread out in different directions: toward the cerebellum, the motor nucleus of $\mathrm{V}$, the corpora quadrigemina anteriora and posteriora, i.e., toward those formations with which the cells are chiefly connected by means of their processes.

In all reptiles and birds studied by us the cells are found in a medial position, in the roof of the aqueduct, as well as in a lateral position, in the optic lobes. Corresponding to this, a lateral and a medial group have been distinguished. In general, the cells of the medial group, except some of the most frontal ones, differ distinctly in appearance from those 
of the lateral group. The characteristies of both kinds of cells have been considered in. the course of the description of the nucleus in the respective forms studied. The numerical relation of the lateral cells to the medial ones in different forms is given in table 1 . It shows that the medial position is most pronounced in dove and duck and relatively least pronounced in sparrow and alligator. In mammals the

TABLE 1

Number of cells of the nucleus of the mesencephatic root of $V$, in the different forms studied

\begin{tabular}{|c|c|c|c|c|c|c|}
\hline ANIMAL & $\begin{array}{l}\text { IAATERAL } \\
\text { ORLLS }\end{array}$ & $\begin{array}{l}\text { INTER- } \\
\text { MEVIATE } \\
\text { CETLLS }\end{array}$ & $\begin{array}{l}\text { MEDIAL } \\
\text { CELLS }\end{array}$ & $\begin{array}{c}\text { MEDIAT } \\
\text { PLUS } \\
\text { INTER- } \\
\text { MEDIAT } \\
\text { OELLS }\end{array}$ & TOTAL & $I_{3}: M^{1}$ \\
\hline Amia calva & 26 & & 52 & & 78 & $1: 2$ \\
\hline Brook-trout & 88 & & & & 88 & \\
\hline Frog & 176 & 187 & 71 & & 434 & $1: 2$ \\
\hline Turtle & 192 & & 345 & & 537 & $1: 1.8$ \\
\hline Alligator & 1295 & 779 & 619 & 1398 & 2693 & $1: 1$ \\
\hline Chicken & 1306 & & 1778 & & 3084 & $1: 1.25$ \\
\hline Duck & 891 & & 2336 & & 3227 & $1: 2.5$ \\
\hline Dove & 213 & & 907 & & 920 & $1: 3$ \\
\hline Sparrow & 676 & & 757 & & 1433 & $1: 1$ \\
\hline Albino rat & 2882 & & & & 2882 & \\
\hline Cat & & & & & 3077 & \\
\hline Monkey & & & & & 4869 & \\
\hline Man & & & & & 5735 & \\
\hline
\end{tabular}

${ }^{1}$ Relation of the number of lateral cells to that of the medial; the number of intermediate cells is included into the number of medial cells.

mediodorsal position is found only in Monotremata and Marsupialia (van Valkenburg, '11). In other orders, cells in the roof of the aqueduct or in the anterior medullary velum are, in general, relatively few in number. In our material a dorsal position of the cells. of the mesencephalic root of $V$, with reference to the aqueduct and IV th ventricle, is practically not observable in rat and mouse. In rabbit, man, and horse (van Valkenburg) some cells are located in the anterior medullary velum above the lateral angle of the 
IVth ventricle. In man, also in cat and monkey, relatively few cells are present above the aqueduct. The arrangement, aspect, and relatively small number of these mediodorsal cells do not justify their separation as a distinct group such as was made for submammals. The cells of the mesencephalic root of $\mathrm{V}$ in the midbrain extend in mammals farther ventralward than in submammals. In our material this is least pronounced in the cat. In man these ventral cells enter into a close relationship with the oculomotor and trochlear nuclei, being found occasionally even amid the cells of these nuclei.

In the forms studied by us the greatest number of cells of the mesencephalic root of $\mathrm{V}$ is found in man and monkey (table 1). The number is least in fishes and in the frog and turtle. Of particular interest, on the one hand, is the relatively great number of cells in the alligator, which number is almost as great as in the rat, and, on the other hand, the small number in dove and sparrow in comparison with chicken and duck. In all mammals studied by us the caudal portion of the nucleus of the mesencephalic root of $V$ reveals a quite evident augmentation of its nuclear masses as determined by careful serial count, section by section. In the cat, rat, mouse, and rabbit this augmentation corresponds approximately to the level of the trochlear decussation; in monkey it begins slightly frontal to this decussation, while in man it is observed farther distalward in the region of the motor nucleus of $\mathrm{V}$. In cat, monkey, and man relatively considerable nuclear masses of the mesencephalic root of $\mathrm{V}$ are situated also in the region of the oculomotor nucleus. In rat, rabbit, and mouse the nucleus of the mesencephalic root of $\mathrm{V}$ is not so well pronounced in the oculomotor region. The nucleus reveals in cat, monkey, and man a certain decrease in the region of the corpora quadrigemina posteriora, in front of its caudal augmentation; in rodents this decrease is not so obvious, since the cells of the whole frontal portion of the nucleus are few in number, the main nuclear masses being located in these animals caudal to the trochlear cross- 
ing. S. Ramón y Cajal ('09) describes the nucleus of the mesencephalic root of $\mathrm{V}$ in rabbit, mouse, and cat as consisting of a superior part, or tail, and an inferior part, or head of the nucleus. The former is composed of scattered cells, while the latter part is more compact and corresponds to the portion of the nucleus which reveals the above-described augmentation. Different authors have called attention in mammals to the arrangement of the cells of the mesencephalic root of $\mathrm{V}$ into small groups. This grouping is more evident in the ventral than in the dorsal part of the midbrain portion of the nucleus. It is more pronounced in man and monkey, less in cat, and still less in rodents.

In mammals the cells of the mesencephalic root of $V$ in the midbrain are situated usually at the inner border of the stratum album profundum. They are more often removed relatively farther inward from this stratum in man than in other forms. In submammals the lateral cells lie also inside the deep medullary layer. In birds they are confined exactly to the inner border of this layer, as in mammals. In fishes, amphibians, and reptiles their position within those tectal layers which are situated internal to the deep medullary substance is variable. Sometimes, they are located even among the ependymal cells. Such a deep position is especially well marked in selachians and Necturus, where, according to Johnston ('09), they sometimes seem to form the wall of the ventricle, pushing aside the ependymal cells. In larval Amblystoma and Desmognathus, Johnston has occasionally seen the cells of the mesencephalic root of $\mathrm{V}$ in a superficial position similar to that described by Harrison ('01) for the giant cells of the cord in the trout embryos.

II. Character of cells. According to S. Ramón y. Cajal ('09), the cells of the inferior part of the nucleus of the mesencephalic root of $\mathrm{V}$ of mammals are larger in size than those of the superior. This agrees on the whole with our observations, since a greater proportion of larger cells, which are frequent in the dorsal part of the tectal portion, are very rare in pontine levels. The cells of the mesenceph- 
alic root of $\mathrm{V}$, in mammals, in size and appearance approach more nearly the lateral than the medial cells of reptiles and birds (table 2). In general, the medial cells of these submammals are, except the most frontal ones, smaller and

TABLE 2

Average sizes of the cells of the nucleus of the mesencephalic root of $\nabla$, given in micra

\begin{tabular}{|c|c|c|c|c|c|c|}
\hline \multirow{2}{*}{ ANIMAL } & \multicolumn{2}{|c|}{ MEDIAI CEIILS } & \multicolumn{2}{|c|}{ INTHRMEDIATE CELLS } & \multicolumn{2}{|c|}{ LATERAI, OKLLS } \\
\hline & Short axis & Long axis & Short axis & Long axis & Short axis & Long axis \\
\hline Amia & 16 & 27 & & & 22 & 27 \\
\hline Trout & & & & & 16 & 23 \\
\hline Frog & 18 & 24 & 13 & 26.4 & 15.4 & 21 \\
\hline Turtle & 18 & 23 & & & 23.7 & 27 \\
\hline Alligator & 14.4 & 17.2 & 14.8 & 18.3 & 22 & $24: 3$ \\
\hline Chicken & 18 & 25 & & & 27 & 31 \\
\hline Duck & 16 & 35.9 & & & 25 & 37 \\
\hline Dove & 15.5 & 29 & & & 24.9 & 32.5 \\
\hline Sparrow & 12.5 & 22 & & & 20 & 24 \\
\hline Albino rat & & & & & 20 & 25 \\
\hline Cat & & & & & 28.25 & 35.54 \\
\hline Monkey & & & & & 22.4 & 31.6 \\
\hline Man & & & & & 28 & 35 \\
\hline
\end{tabular}

TABLE 3

Differences between longest and shortest axes of the different cells of the several divisions of the nucleus of the mesencephalic root of $V$, given in miora

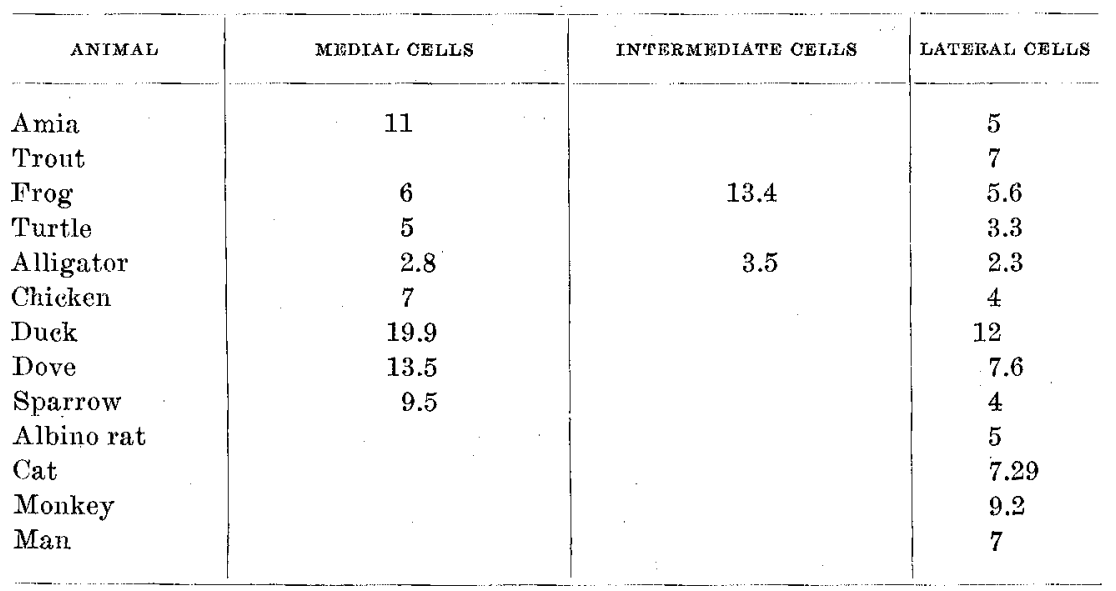


more elongated, the difference of the average shorter and longer axes being greater in the medial than in the lateral cells (table 3 ). In mammals cells similar in appearance to the medial cells of birds are rare. They are observed in cat in the region of the posterior colliculus and sometimes in man in the anterior medullary velum, being located in close relation to the fiber masses of these regions. It is probable that this close relation to the fiber masses is responsible for their different appearance, since the medial cells in submammals lie among the fibers of the tectal commissures. The size of cells of the mesencephalic root of $\mathrm{V}$ is smaller in foetuses and embryos than in adult animals. According to Lugaro ('95), the cells in rabbit embryos are of 15 to $35 \mu$. The sizes of the cells of the mesencephalic root of $\mathrm{V}$ for man, as given by Schwalbe ('81), are 60 to $70 \mu$ (largest diameter), by Obersteiner ('01), 45 to $60 \mu$, by Meynert ('72), 45 to $50 \mu$ in breadth and $60 \mu$ in length. Terni ('12) gives the measurements as $19 \times 15 \mu$ for the cells of the mesencephalic root of $\mathrm{V}$ in the rat. The smallest average size of cells of the mesencephalic root of $\mathrm{V}$ was observed by us in the trout and in the frog. The lateral cells in birds, especially in the duck, are relatively large; they approach in size the cells in adult cat, monkey, and man. In general, in the rat and in the other rodents the cells are smaller than in other mammals studied by us. Cells of a size approaching that given for man by the above-quoted authors occur in our human material, but the average size obtained by us was less. The small dorsal cells in man are approximately from 18 to $20 \mu$. A classification of the cells according to their size is difficult to make, since transitional sizes occur. This refers also to other mammals studied by us.

In adult mammals most cells of the mesencephalic root of $\mathrm{V}$ seem to be provided with only one process, although cells with two or more processes also occur. In embryos the cells with more than one process are much more frequent. The medial cells of reptiles and birds seem to be for the most 
part multipolar, while in the lateral cells a bipolarity or multipolarity is nearly as rare as in adult mammals. A unipolarity of the cells of the mesencephalic root of $V$ has been assumed by Golgi ('93), Bickel ('02), while Schwalbe ('81), Merkel ('74), and Forel ('77) think that the cells are bipolar. Van Gehuchten ('95), Deiters ('65), Kohnstamm and Quensel ('08) have observed unipolar as well as bipolar cells, while Terterjanz ('99), Kölliker ('96), Held ('93), Obersteiner ('01), and Terni ('12) are of the opinion that the cells of the mesencephalic root of $\mathrm{V}$ are multipolar. According to S. Ramón y Cajal ('96), in the course of development the cells change from multipolar to unipolar types. According to Johnston ('09), the multipolar cells are more common in lower vertebrates and embryos than in higher vertebrates and adult animals. This agrees with our observations. Johnston considers the cells of the mesencephalic root of $\mathrm{V}$ as, elements of the neural crest which are not cut off when the tube was formed by rolling up of the medullary folds of the midbrain. The similarity in appearance of the cells of the mesencephalic root of $\mathrm{V}$ to that of the cells of cerebrospinal ganglia has been noticed by many observers (Deiters, '65; Meynert, '72 ; Kure, '99). However, the former cells differ from the latter cells in their lack of capsules and of glomeruli of origin (Cajal,' '09). Our observations are in accord with the point of view of Johnston ('09), who considers the thick processes of the cell of which the mesencephalic root of $\mathrm{V}$ is formed as the dendrites. Such a process contains often tigroid granules, while the opposite process of a bipolar cell reveals sometimes a true axon hillock. In a multipolar cell, occasionally, more than one process is stained at its beginning in toluidin-blue preparations. Whether all the stained processes enter the root or some of them take a different course cannot be decided from our material. Johnston ('09) assumes with Lugaro ('95) and S. Ramón y Cajal ('96), that the collateral branching is the chief form of branching in manmals. However, in selachians and in the toad Johnston has observed the large process 
to divide sometimes at a short distance from the cell body into a thick and a slender branch. Such a branching in a T-shaped manner has been observed in our mouse embryos. It appears justifiable to assume that the embryonic multipolar cells of mesencephalic root of $V$ become unipolar in the course of development. During this development the thick process (dendrite) is joined by the slender one (axon). In higher stages of development the slender process accompanies in part the thick one for a longer or shorter distance and poses, therefore, as collateral branehes of the main process. Willems ('11) has observed cones of origin in the collateral branches. These branches and the slender processes of the cells of the mesencephalic root of $\mathrm{V}$ enter into relation with different elements in the optic tectum and in the region of the pons, while the main process, representing the dendrite, runs in the peripheral nerve.

III. Connections. According to different observers, the nucleus of the mesencephalic root of $\mathrm{V}$ is related by means of its fibers to the following formations: 1) optic tectum (Johnston, '09), 2) substantia reticularis mesencephali (Willems, '11), 3) cerebellum (Wallenberg, '04; Willems, '11; Larsell, '23), 4) nucleus loci coerulei (Held, '93; Willems, '11), 5) neighboring cells of the mesencephalic root of $\mathrm{V}$, by means of recurrent collaterals (Willems), 6) motor nucleus of V (S. Cajal, 96), 7) nucleus Deitersi and glossopharyngeal-vagal nucleus (Probst, '99), 8) nucleus of the VIIth nerve (Herrick, '14), 9) the mesencephalic root of $V$, being formed by the main processes.

All these connections, except the last one, are made possible by means of the slender fibers or collateral branches of the main processes. The connections within the midbrain, with the cerebellum and the motor nucleus of $V$, are shown also in our material. In submammals the neurones of the mesencephalic root of $\mathrm{V}$ seem to enter into relation with elements of different layers of the optic tectum. In mammals the cells of the mesencephalic root of $\mathrm{V}$ are probably related. to the neurones of the central gray, collaterals from their 
main processes to this gray having been observed by Held ('93). A descending bundle from the mesencephalic root of $\mathrm{V}$ toward the Deiters', the glossopharyngeal-vagal, and facial nuclei has been seen also by us. Collateral branches from the root fibers of the mesencephalic root of $V$ to the nucleus loci coerulei are recorded by Held ('93).

It seems probable to us that, in addition to the abovequoted connections, there exists in man also a connection of the cells of the mesencephalic root of $\mathrm{V}$ with the oculomotor and trochlear nuclei. This is suggested by the very close relationship in the human material of the cells of the mesencephalic root of $\mathrm{V}$ and their root fibers with the elements and root fibers of the nuclei of III and IV and by the fact that occasional, perhaps aberrant, cells of the mesencephalic root of $\mathrm{V}$ can be found in man even inside of these nuclei. It cannot be decided in our material whether the neurones of the mesencephalic root of $V$ enter into connection with the elements of these eye-nerve nuclei by means of their slender processes or whether the dendrites of the cells of the mesencephalic root of $V$. join the root fibers of III and IV to leave the brain with these roots. The previously quoted findings of McKibben ('13) in Necturus and the statements of Davidson Black ('17) and Larsell ('23) with regard to the relations in frog speak in favor of the last alternative. Winkler ('18) states also that some fibers of the mesencephalic root of $V$, the cells of which can sometimes be found in the oculomotor nucleus, join the IIIrd, IVth, and possibly, the VIth nerve. However, the explanation of Winkler that some of such fibers may return to the trigeminal nerve by sympathetic connections seems to be, as Freeman ('25) justly remarks, rather far-fetched. An interlacing of the root fibers of the mesencephalic root of $\mathrm{V}$ with those of the trochlear root has been by us often noticed in mammalian, as well as submammalian, forms. It seems thus quite probable that some of the root fibers of the mesencephalic root of $\mathrm{V}$ join the trochlear nerve. However, this cannot be proven with certainty in normal preparations. The fact that 
in man cells of the mesencephalic root of $V$ can be seen which, lying closely dorsal to the medial longitudinal fasciculus, give their process ventralward toward the oculomotor root fibers, justifies, in our estimation, the assumption that some of the root fibers of the mesencephalic root of $V$ are also associated with the outgoing IIIrd root.

IV. Relation to the nucleus loci coerulei. Meynert ('72) derives a part of the mesencephalic root of $V$ from the substantia ferruginea ${ }^{7}$ and from the longitudinal fasciculi of the 'anterior divisions of the pons' ('middle and internal descending root'), in addition to the origin from the vesiculoid cells around the aqueduct ('external descending root'). Forel ('77) considers the origin of the root from the substantia ferruginea and the dorsal part of the raphe as only an apparent one. Allen ('19) derives a part of the mesencephalic root of $V$ from the nucleus loci coerulei, which is considered by him as a caudal continuation of the nucleus of the mesencephalic root of $V$. We could not see any fibers from the cells of the nucleus loci coerulei proper or the substantia ferruginea entering the bundles forming the root fibers of the mesencephalic root of $V$. The fibers of this root at certain levels are intimately related topographically to the nucleus loci coerulei, but originate from the cells of the mesencephalic root of $\mathrm{V}$, which are entirely different from the true cells of the nucleus loci coerulei, though sometimes closely intermingled with them. This agrees with the statements of Schwalbe ('81), Cajal ('09), and with the fact that no alterations are observed in the cells of the nucleus loci coerulei after severing of the Vth nerve (Kohnstamm, '10; May and Horsley, '10; Kosaka, '12). The statements of Meynert ('72), Obersteiner ('92), Cramer ('94), Kölliker ('96), Terterjanz ('99), and Allen ('19) as to the origin of the root fibers of the mesencephalic root of $\mathrm{V}$ from the locus coeruleus or substantia ferruginea may be applied, therefore, only to those elements of the mesencephalic root of $\mathrm{V}$. which lie among the cells of the nucleus loci coerulei; not, however,

${ }^{7}$ See footnote, page 328 . 
to the neurones which properly belong to the nucleus loci coerulei (Kure, '99).

$V$. Relation to the trochlear root. The root fibers of the mesencephalic root of $\mathrm{V}$ lie in the frog and in all reptiles and birds studied by us lateral to the trochlear root. They lie lateral to the IVth root also in man and monkey, while in Carnivora (cat, Duval, '78; Hulles, '07; cat, dog, Obersteiner, '92; Chiroptera, Artiodactyla, and partly, Natantia, Hulles, '07); the trochlear root lies lateral to the mesencephalic root of $V$. In rodents the trochlear root lies partly lateral, partly medial to the fiber bundles of the mesencephalic root of $V$ and a close interlacing of both fiber masses takes place while the roots cross each other (Duval, '78; Hulles, '07; van Valkenburg, '11).

VI. Question of possible decussation of the mesencephalic root of $V$. A decussation of the root fibers of the mesencephalic root of $\mathrm{V}$ has never been observed in our material. It has been assumed by Hulles ('07) in Primates and by Valeton ('08), as a partial crossing, in Bruta, Marsupialia, Natantia, Artiodactyla. However, Grossmann ('06) found in monkey, after cutting of all roots of $\mathrm{V}$, only a very slight degeneration of the mesencephalic root of $V$, on the contralateral side, while the root of the same side revealed a quite evident degeneration. A crossing is assumed by Ponjatowsky ('92) in the eagle-owl. Herrick ('14) has observed a partial crossing in the decussatio veli in Necturus and Amphiuma. According to van Londen ('07), about onethird of the root fibers of the mesencephalic root of $V$ of rabbit are crossed. H. Gudden ('92) was not able to eliminate entirely a possibility of a partial crossing in calf and rabbit. No crossed fibers could be found by Mahaim ('08) in guinea-pig, or by P. Ramón ('04) in amphibians, birds, and reptiles. A decussation of the root fibers of the mesencephalic root of $V$ in rabbit, guinea-pig, dog, cat, and monkey has been rendered very improbable by the experimental works of Kure ('99), May and Horsley ('10), Kosaka ('12), and Allen ('19). 
VII. Emergence of the mesencephalic root of $V$ from the brain. Some controversy has existed as to whether the root fibers of the mesencephalic root of $V$ leave the brain together with the motor or with the sensory fibers of $V$. According to the data of Bregmann ('92, rabbit), Ferrier and Turner ('93), Henle ('79), Forel ('77), H. Gudden ('92, calf), Haller ('00, mouse), ${ }^{8}$ Edinger ('11), Krause ('05, man), Kure ('99, rabbit), Obersteiner ('01), Ponjatowsky ('96, man, cat, horse, guinea-pig, dog, eagle-owl), Kljatschkin ('97, cat), Willems ('11, rabbit), May and Horsley ('10, cat, monkey), Kosaka ('12), Allen ('19, guinea-pig), at least the main fiber masses join the motor root of V. According to van Londen ('07, rabbit) and Thelander ('24, eat), some fibers of the mesencephalic root of $V$ may enter the sensory root of $V$, while the greatest part of them associate themselves with the motor root. Merkel ('74) and Probst ('99, cat) described the mesencephalic root of $\mathrm{V}$ as lying between the motor and sensory root of $V$. Bechterew ('87), Mendel ('88, man), Winkler and Potter ('14, cat), Johnston ('09, all orders of vertebrates), and van Valkenburg ('11, all orders of vertebrates) believe that the root fibers of the mesencephalic root of $\mathrm{V}$ enter the portio major. According to van Valkenburg, only Scyllium canicula represents in this respect an exception. It is easily shown in our material that, in all cases where the root fibers of the mesencephalic root of $\mathrm{V}$ can be traced out to the level of its exit, its main fiber masses intermingle with those of the motor root of $V$. However, the possibility that a few of the root fibers of the mesencephalic root of $\mathrm{V}$ associate with the sensory fibers of $\mathrm{V}$ cannot be eliminated.

VIII. Ascending and descending fibers in the mesencephalic root of $V$. A clinical case studied by May and Horsley

\footnotetext{
${ }^{8}$ Haller has been able to trace into the motor portion of $V$ only this part of the mesencephalic root of $\mathrm{V}$ which arises from the pontine portion of the nucleus. Some fibers arising from the midbrain portion of the nucleus form, according to this author, the crossed trochlear root, while others terminate among the pontine cells of the mesencephalic root of $V$ and in the motor nucleus of $\mathrm{V}$.
} 
('10) and the experimental works of these authors and that of Allen ('19) have shown that after a lesion of the ganglion Gasseri or the roots of $V$, some of the root fibers of the mesencephalic root of $\mathrm{V}$ reveal an ascending degeneration. Kosaka ('12) considers this degeneration as a retrograde one. May and Horsley regard centripetally degenerated fibers as arising from the semilunar ganglion. Allen ('19, '25) assumes also that a part of the cells of the mesencephalic root of $\mathrm{V}$ are situated outside the brain. Ganglionic cells found by him in eat along the course of the motor root of $\mathrm{V}$ are regarded as migratory cells of the mesencephalic root of $V$. In a rabbit embryo a few cells of the mesencephalic root of $\mathrm{V}$ were seen by us in a very distal position at the point of exit of the trigeminal roots. Therefore, the assumption of May and Horsley and of Allen seems to us quite justified. The mesencephalic root of $\mathrm{V}$ is thus composed in higher mammals chiefly of dendritic processes of the cells of the nucleus of the mesercephalic root of $V$, but partly also of axons of cells having more distal positions.

IX. Peripheral distribution. The peripheral distribution of the root fibers of the mesencephalic root of $V$ has been elucidated by the experimental works of May and Horsley ('10), Willems ('11), Kosaka ('12), Allen ('19), and Thelander ('24). May and Horsley found chromatolytic changes in the cells of the mesencephalic root of $\mathrm{V}$ of cat and monkey after a section of the third branch of the $V$ th nerve, but no alterations resulted after a severing of the first or second branch. Since these authors could not see any degeneration in Marchi material in the $V$ th nerve distal to the gasserian ganglion, but only in the motor root of $\mathrm{V}$, after a lesion of the nucleus of the mesencephalic root of $\mathrm{V}$ within the brain, they concluded that the fibers of the mesencephalic root of $\mathrm{V}$ terminate in the gasserian ganglion. Kosaka ('12) thinks also, that some fibers of the mesencephalic root of $V$ end before reaching the terminal distribution of the branches of the trigeminal nerve. Chromatolytic changes in the cells of the mesencephalic root of $V$ of rabbit have been observed 
by Willems after a section of the masseter, sphenoidal, temporal, internal and external pterygoid nerves and, though to a much lesser degree, after a severing of the $\mathrm{m}$. tensor tympani. No chromatolysis of the cells of the mesencephalic root of $\mathrm{V}$ was produced by a section of the digastric and mylohyoid nerves. Kosaka saw, in contradistinction to May and Horsley, a few degenerated cells of the mesencephalic root of $\mathrm{V}$ on the side of the lesion after cutting of the branches of the maxillary nerve in $\operatorname{dog}$ and monkey, but this was not observed in rabbit. The chromatolysis of the cells of the mesencephalic root of $V$ on the side of the lesion was well pronounced after a destruction of the mandibular nerve in dog and rabbit, but no changes resulted in these cells after a severing of the ophthalmic nerve. Allen ('19), who cut the trigeminal roots of guinea-pig immediately behind the semilunar ganglion and the mesencephalic root of $V$, within the brain, studied the root in Marchi preparations. He concludes that the descending fibers of the mesencephalic root of $\mathrm{V}$, derived from the cells in the mesencephalon, enter the motor divisions of the $V$ th nerve, except its mylohyoid branch. The ascending fibers originating from the cells in the semilunar ganglion are regarded as carrying the muscle sense from the mylohyoid and digastric muscles and entering the main mandibular nerve through the mylohyoid nerve. Thelander ('24) could trace the root fibers of the mesencephalic root of $\mathrm{V}$, after a lesion of the nucleus in the midbrain of eat, into the masseter, temporal, and pterygoid nerves. Thus, all these experimental works show that the main fiber masses of the mesencephalic root of $\mathrm{V}$ enter the branches of the mandibular nerve and that only a few associate in certain forms, possibly, with the maxillary nerve. In contradistinction to these findings is the clinical observation of van Valkenburg ('11). This author reports a case of tumor in man which had destroyed the ophthalmic nerve without having produced any alterations in the maxillary and mandibular nerves. In this case the cells and root fibers of the mesencephalic root of $\mathrm{V}$ were altered on the side of the 
lesion. Van Valkenburg thinks, therefore, that some fibers of the mesencephalic root of $\mathrm{V}$ enter together with the ophthalmic nerve into the orbits. Freeman ('25) believes that in this case the alterations of the cells of the mesencephalic root of $\mathrm{V}$ may have been produced by the involvement of the nerves to the extrinsic muscles of the eye. Further pathological observations which would be suitable for the elucidating of the distribution of the root fibers of the mesencephalic root of $\mathrm{V}$ in man are lacking. Such eases as those presented by Mendel ('88), Homén ('90), Hagelstam ('98), and May and Horsley ('10) involve all the divisions of the trigeminal nerve, and are thus not pertinent to the question. In the case of Tooth ('93) the fifth trunk, motor and sensory, was completely involved by a gumma, but the fibers of the mesencephalic root of $V$ were quite unaffected and presented a normal appearance.

$X$. Function. Clinical and experimental observations do not provide any convineing data as to the functional character of the nucleus of the mesencephalic root of $V$. The resemblance in appearance of the cells of the mesencephalic root of $\mathrm{V}$ to those of the cerebrospinal ganglia would suggest a sensory function. Difficulties in establishing such a function were met with in the position of the nucleus inside the brain proper and in the fact that the cutaneous innervation supplied by $\mathrm{V}$ nerve had for a long time been definitely known to be associated with the neurones of the gasserian ganglion. Huguenin ('79) assumes a vasomotor function, Held ('93), a secretory, Merkel ('74) and Mendel ('88), a trophic. The trophic function is denied by Eckhard ('76), Duval ('79), Moebius ('95), and Oppenheim ('13). Nor is there any evidence for either a secretory, vasomotor, or trophic function in the cases of Hagelstam ('98) and Morriston Davies ('07). Kölliker ('96) assumes that the mesencephalic root of $V$ is a motor nerve for the $\mathrm{m}$. tensor veli palatini and for the $m$. tensor tympani; Terterjanz ('99), for the tensor veli palatini. Kohnstamm and Quensel ('08) regard the mesencephalic root of. $\mathrm{V}$ as a visceromotor nerve 
for the eye muscles and as: a motor root of the frontal metamere of $V$. They say:

Die peripherische Ausbreitung der Radix mesencephalica V kommen wir uns mangels weiterer Trigeminus-muskulatur nur im Schling-und Kauapparat vorstellen, nachdem, wir die Möglichkeit ausgeschlossen haben, dass sie etwa der Sensibilität der Augenmuskeln dienen könnte. Da aber nach den zentralen Verhältnissen eine Beziehung der Radix mesencephalica zum Auge vermutet werden muss, wird es gut sein, sich die Angabe Wiedersheims gegenwartig zu halten, dass bei Amphibien, Reptilien und Vögeln ein Teil der Trigeminusmuskelatur in die fibröse Wand der Periorbita übernommen und der Bewegung des Bulbus, des unteren Lides und der unteren Wand des Orbitalsackes dienstbar gemacht ist.

An efferent function of the mesencephalic root of $\mathrm{V}$ has been assumed also by van Gehuchten ('95), Bruce ('98), Mahaim ('08), Cajal ('09), Jacobson ('09). The main arguments in favor of a motor function of the mesencephalic root of $\mathrm{V}$ are its relation to the motor root of $\mathrm{V}$, the situation of the cells of origin inside the brain, the relative thickness of its fibers, the lack of any other explanation (Kölliker, '96), and the degeneration of the cells after an extracranial section of the Vth nerve (S. Cajal, '09).

An afferent character of the mesencephalic root of $V$ has been suggested by Meynert ('72), Duval ('79), Wernicke ('81), van Londen ('07), Johnston ('09), Willems ('11), Edinger ('11), Kosaka ('12), Allen ('19), Thelander ('24). Moebius ('95) considers it as a sensory nerve for the eye, mediating painful sensations from within the eye. Johnston ('09) points out in a series of animals that the nucleus of the mesencephalic root of $\mathrm{V}$ is always located in the alar plate, a position characteristic of sensory nuclei. Kosaka ('12) calls attention to the fact that in certain lower vertebrates (Amphioxus, Petromyzon, teleosteans, selachians) the spinal ganglia cells are very often found inside the medulla, as the studies of Johnston ('00), Edinger ('08), and others have shown. Therefore, the intracerebral position of the nucleus of the mesencephalic root of $V$ does not necessarily mean function other than sensory. The appear- 
ance of a cell of the mesencephalic root of $V$ is quite different from that of the usual motor cell. Willems ('11) thinks that the mesencephalic root of $\mathrm{V}$ is a proprioceptive organ carrying the muscle sense from the masticatory muscles. According to this author, the reasons for a sensory function are its dorsal position, its connections, which are those characteristic of a sensory path, the absence of a connection with the pyramidal path, and the myelination of the fibers at a different period from that of the fibers which arise from the motor nucleus of V.9 Willems ('11) has also shown that the relation of the number of the cells of the mesencephalic root of $V$ to the total number of cells of the nuclei of the masticatory root and the mesencephalic root of $V$, and the relation of the number of root fibers of the mesencephalic root of $V$ to the total number of fibers in the motor branches of $V$ correspond approximately to the relation of the number of sensory fibers in a muscle nerve to the total number of fibers in this nerve, that is, about 35 per cent, as these relations have been found by Sherrington ('94) and by Dunn ('09). Clark ('26) has noted that the cells of the mesencephalic root of $\mathrm{V}$ show a resemblance in the arrangement of their Nissl granules to the type of spinal ganglion cells which have been demonstrated by Warrington and Griffith ('04) to be related to the muscle spindles.

The proprioceptive function of the mesencephalic root of $\mathrm{V}$ is admitted by Edinger ('11), Allen ('19), Kappers ('20), Freeman ('25). This point of view explains the distribution of the root fibers of the mesencephalic root of $\mathrm{V}$

\footnotetext{
${ }^{9}$ Nicolesco ('26) speaks of the nucleus of the mesencephalic root of $\mathrm{V}$ as of a "noyau mésencéphalo-protubérantiel à cellules vésiculeuses," which is con. sidered by him as forming, together with the column of Clarke and the nucleus of Monakow, a unique system, intercalated in the paths of proprioceptive sensibility. He states that the myelination of the fibers of the vesiculous cells is produced at the same time as that of the paths for general and proprioceptive sensibility. He finds further similarity of the vesieulous cells to the sensory neurones, to those of the column of Clarke, of the nueleus of Monakow, and of the substantia innominata of Reichert. Our point of view agrees with that of Freeman ('25), according to whom the cells of the mesencephalie root of $V$, as primary neurones, cannot be conceived of as the actual homologue of the cells in the column of Clarke, which latter are neurones of the second order.
} 
in the masticatory muscles and agrees with the fact that the intramedullary ganglion cells of certain lower vertebrates give off a branch to the muscle, in addition to the one to the skin (Coghill, '14; Herrick and Coghill, '15; Kappers, '19). Thus the proprioceptive nature of the mesencephalic root of $\mathrm{V}$ and its relation to the masticatory muscles seems at the present time to be more or less generally admitted.

$X I$. Relation to the eye muscles. It has been. shown by the observations of Huber ('99, '00) and Sherrington and Tozer ('10) that sensory endings are present in the eye muscles. The afferent fibers from these muscles are not contained in the optic nerve nor in the ophthalmic branch of the Vth nerve, but chiefly within the eye-muscle nerves themselves, as Sherrington ('97, '98) and Sherrington and Tozer ('10) have demonstrated in a series of experimental studies carried out on rabbit, cat, and monkey. They may be derived from the ganglionic cells which are found by Nicholls ('15) along the root of III in Scyllium canicula and Nicholson ('24) in the IIIrd and VIth nerves of man. These ganglionic cells would be then comparable with the extracerebral ganglionic cells found by Allen ('25) within the motor root of $V$ of cat, the connection of which with the mesencephalic root of $V$ has been pointed out by this author. However, according to Clark ('26) the cells in the IIIrd, IVth, and VIth nerves are inconstant and different in the arrangement of their Nissl granules from the cells of the mesencephalic root of $\mathrm{V}$ and from the presumably proprioceptive cells of the spinal ganglia. Ranson ('27) admits, therefore, the possibility that proprioceptive fibers to the eye muscles may come from the mesencephalic root of $V$, or some other similar nucleus in the brain stem. The possibility of such a function of the mesencephalic root of $\mathrm{V}$ was eliminated by Kohnstamm and Quensel ('08) on the ground that the cells of this root do not change after a resection of the eye muscles. Neither could Tozer ('12) observe any alterations in these cells after cutting the IIIrd and IVth nerves. However, Freeman ('25) and Clark ('26) call attention to the fact that, after a section 
of the branches of the Vth nerve, some of the cells of the mesencephalic root of $\mathrm{V}$ are left intact, as the works of the authors who have experimented with chromatolysis in these cells have shown. It is inferable then that not all cells of the nucleus of the mesencephalic root of $\mathrm{V}$ can be considered with reference to the trigeminal nerve alone. Later ('27), Freeman could observe a degeneration of the mesencephalic root of $\mathrm{V}$ and of its cells of origin at the level of the oculomotor and trochlear nuclei after removal of the whole contents of the orbit in cat. No changes resulted in the root after a simple enucleation of the eyeball. In view of these considerations, the previously discussed probability that some of the fibers of the mesencephalic root of $\mathrm{V}$ may associate in man, Necturus, and frog with the IIIrd and IVth nerves provides a certain support to the assumption that also the muscle sense from the eye muscles is, at least, partly transmitted by the neurones of the mesencephalic root of $\mathrm{V}$.

The position of the cells of the mesencephalic root of $V$ in the region of the tectum opticum may be explained by the necessity for an immediate transmission of sensory impulses from the periphery to the tectum. Perhaps the displacement of the cells in the course of phylogenetical development to more caudal regions is, in addition to neurobiotactic influences, somewhat connected with the development of the jaw musculature, since, apart from mammals, the nucleus is well pronounced in its caudal portion in snakes with their powerful masticatory muscles (van Valkenburg, '11; Kappers, '20), though in these latter animals the cells of the mesencephalic root of $\mathrm{V}$ are still confined to the midbrain. However, the migration of the elements of the mesencephalic root of $\mathrm{V}$ seems to have been carried out not only toward the masticatory nuclei, which migration in certain forms proceeds apparently even along the extracerebral root of the Vth nerve, but possibly also along the roots of the eyemuscle nerves. However, for the latter assumption, there is no conclusive evidence at hand. 
XII. General conception. The nucleus of the mesencephalic root of $V$ may be conceived of, then, as a part of a proprioceptive system for the masticatory musculature and probably for eye muscles, its elements being comparable to the proprioceptive neurones of the spinal ganglia. The primitive position of this nucleus is in the region of the optic tectum and it transmits the deep sensibility from these muscles to the mesencephalic and metencephalic regions. In the course of phylogenetical development the elements of this system have migrated toward the sources of their greater irritation. They lie, then, in higher vertebrates to a great degree in regions much more caudal and ventral than their original position in the dorsal part of the midbrain.

\section{SUMMARY}

1. The nucleus of the mesencephalic root of $\mathrm{V}$ is located in submammals in the dorsal region of the midbrain and does not extend in these animals caudal to the trochlear decussation.

In mammals, except Monotremata and Marsupialia, the cells of the mesencephalic root of $V$ extend from the region of the posterior commissure to the level of the motor nucleus of $V$.

2. The caudal portion of the nucleus is especially well developed in man and rodents.

3. In many reptiles and birds a medial and a lateral group can be distinguished. The medial group lies in the roof of the aqueduct, the lateral group in the optic lobes. Such a distinction cannot be made in higher mammals, since the cells lie here chiefly lateral to the aqueduct.

4. In all classes the cells of the midbrain portion of the mesencephalic root of $\mathrm{V}$ lie inside the deep medullary layer of the tectum. In birds and mammals they are more or less strictly confined to the inner border of this layer, while in lower forms they are often situated deeper. The main processes of the cells always run into the inner part of the stratum album profundum. These processes form the mesencephalic root of $\mathrm{V}$. 
5. In man and monkey the cells are observed in the midbrain in more ventral regions than in other forms. In man cells can occasionally be found in a very close relationship to the nuclei of the oculomotor and trochlear nerves.

6. In certain mammals the cells of the mesencephalic root of $\mathrm{V}$ can be observed outside the brain. The root is then composed of both axons and dendrites.

7. In adult mammals the cells are mostly unipolar. In embryos and submammals multipolar cells are more frequent than in adult mammals.

8. The main fiber masses of the mesencephalic root of $\mathrm{V}$ leave the brain with the motor root of $\mathrm{V}$.

9. The central connections of the mesencephalic root of $V$ are with different regions of the midbrain and the pons, in the latter chiefly with the masticatory nucleus.

10. The cells of the nucleus loci coerulei proper do not give fibers to the mesencephalic root of $\mathrm{V}$.

11. The proprioceptive nature of the mesencephalic root of $\mathrm{V}$ is very probable.

12. The relation of the mesencephalic root of $\mathrm{V}$ to the masticatory muscles is established; its relation to the eye muscles is very probable.

\section{BIBLIOGRAPHY}

ALLEN, W. F. 1919 The application of the Marchi method to the study of the radix meseneephalica trigemini in the guinea-pig. Jour. Comp. Neur., vol. 30 , p. 169 .

1925 Function of the cells in the motor root of the nervus trigeminus in the cat. Jour. Comp. Neur., vol. 38 , p. 349 .

AnSALONE 1907 Il nueleo motore del V nel mesencephalo degli Uéelli. Areh. d. Psych. e sui affini. (Reference from Willems.)

Bechterew, W. 1887 Über die Trigeminuswurzeln. Neurol. Centrbl., Heft 13, S. 289.

1899 Die Leitungsbahnen im Gehirn und Rüekenmark. Aufl. 2, Leipzig. Verl. Georgi, p. 188.

Brekel, A. 1902 Zur Anatomie des aceessorisehen Trigeminuskerns. Areh. f. mikr. Anat. u. Entw., Bd. 59, S. 270.

Black, Davidson 1917 The motor nuclei of the cerebral nerves in phylogeny. A study of the phenomena of neurobiotaxis. Jour. Comp. Neur., vol. 28, p. 379 . 
Brandis, F. 1895 Untersuchungen über das Gehirn der Vögel. Arch. f. mikr. Anat. u. Entw., Bd. 44, S. 534.

BregManN, E. 1892 Über experimentelle aufsteigende Degeneration motoriseher und sensibler Hirnnerven. Jahrb. f. Psych. u. Neur., Bd. 11, S. 73.

Bruce, Alexander 1898 On the dorsal or so-called sensory nucleus of the glossopharyngeal nerve, and on the nuclei of origin of the trigeminal nerve. Brain, vol. 21, p. 383 .

Burckhard', R. 1892 Das Centralnervensystem von Protopterus annectens. Berlin.

Clark, S. L. 1926 Nissl granules of primary afferent neurones. Jour. Comp. Neur., vol. 41, p. 423.

CogfilLL, G. E. 1914 Correlated anatomical and physiological studies of the growth of the nervous system of Amphibia. I. The afferent system of the trunk of Amblystoma. Jour. Comp. Neur., vol. 24, p. 161.

Cramer, A. 1894 Beitrag zur feineren Anatomie der Medulla oblongata und der Brücke mit besonderer Berücksichtigung des dritten bis zwölften Hirnnerven. (Reviewed in Merkel-Bonnet, Erg. d. Anat. u. Entw., Bd. 4, S. 254.)

Davies, Morkiston 1907 The functions of the trigeminal nerve. Brain, vol. 30, p. 219.

Deiters, OTTo 1865 Untersuchungen über das Gehirn und Rückenmark der Säugetiere. Braunschweig, S. 91.

DunN, Eltzabetr Hopkins 1909 A statistical study of the medullated nerve fibers innervating the legs of the leopard frog, Rana pipiens, after unilateral section of the ventral roots. Jour. Comp. Neur., vol. 19, p. 685 .

DUVal, Matmias 1878-1879 Recherches sur l'origine réelle des nerves eraniens. Journ. de 1'Anat. et de la Phys., T. 14, p. 451, and T. 15, p. 492.

ECkHARD, C. 1876 Über die trophische Wurzel des Trigeminus. Beitr. zur Anat. u. Physiol., Bd. 7, s. 143.

Economo, C. J., Und Karplus, J. P. 1909 Zur Physiologie und Anatomie des Mittelhirns. Arch. f. Psych., Bd. 46, S. 275, 377.

EDINGER, L. 1908-1911 Vorlesungen über den Bau der nervösen Zentralorgane. Bd. 1 und 2, Leipzig.

Ferrier, D., and Turner, W. A. 1893 A record of experiments illustrative of the symptomatology and degenerations following lesions of the cerebellum and its peduncles and related structures in monkeys. Proc. Roy. Soe. London, vol. 54, p. 476.

ForeL, AUG. 1877 Untersuchungen über die Haubenregion und ihre oberen Verknüpfungen im Gehirne des Menschen und einiger Säugetiere, mit Beiträgen zu den Methoden der Gehirnuntersuchung. Arch. f. Psych., Bd. 7, S. 393.

Frankl-Hochwart, L. 1902 Zur kemntnis der Anatomie des Gehirnes der Blindmaus (Sphalax typhlus). Arb. a. d. Wien. Neur. Inst., Bd. 8, S. 190 .

Freemain, W. 1925 The brain stem of man. Folia Neuropath. Estoniana, vol. $3 \cdot 4$, p. 27 . 
Freman, W. 1927 The columnar arrangement of the primary centers in the brain-stem of man. Jour. of Nerv. and Ment. Dis., vol. 65, p. 379.

Ganser, \$. 1882 Vergleichend anatomische Studien über das Gehirn des Maulwurfs. Morph. Jahrb., Bd. 7, S. 591.

van Gehuchten, A. 1895 De l'origine du pathétique et de la racine supérieure du trijumeau. Bull. de 1'Acad. Roy. de Sc. de Belgique, T. 29 ; p. 417.

GoLar, C. 1893 Sur l'origine du quatrième nerve cérébral et sur un point d.histophysiologie générale qui se rattache à cette question. Arch. Ital. de biol., T. 19 , p. 454 .

Goronowinsch, N. 1888 Das Gehirn und die Cranialnerven von Acipenser ruthenus. Morph. Jahrb., Bd. 13, s. 515.

Grossmann, M. 1906 Über die intrabulbären Verbindungen des Trigeminus zum Vagus. Arb. a. d. Wien. Neur. Inst., Bd. 13, S. 194.

Gudden, H. 1892 Beitrag zur Kenntniss der Wurzeln des Trigeminusnerven. Allg. Ztsch. f. Psych., Bd. 48, s. 16.

Hageisstam, J. 1898 Lähmung des Trigeminus und Entartung seiner Wurzeln infolge einer Neubildung in der Gegend des Ganglion Gasseri. D. Ztseh. f. Nervhlk., Bd. 13, S. 205.

Haller, B. 1900 Vom Bau des Wirbeltiergehirns. Morph. Jahrb., Bd. 28, S. 347 .

Harrison, R. G. 1901 Über die Histogenese des peripheren Nervensystems bei Salmo salar. Arch. f. mikr. Anat. u. Entw., Bd. 57, S. 354.

Hatscheck, R., und Schlesinger, H. 1902 Der Hirnstamm des Delphins. Arb. a. d. Wien. Neur. Inst., Bd. 9, S. 1.

HeLd, H. 1893 Beitrag zur feineren Anat. d. Kleinhirns und d. Hirnstammes. Arch. f. Anat. u. Entw., S. 435.

HENLE, J. 1879 Handbuch der systematischen Anatomie des Menschen. Bd. 3, Abt. 2, S. 252. (Edition of 1871 is quoted from Duval, '79.)

Herrick, C. JUdSON 1914 The cerebellum of Neeturus and other urodele Amphibia. Jour. Comp. Neur., vol. 24, p. 1.

1914 The medulla oblongata of larval Amblystoma. Jour. Comp. Neur., vol. 24, p. 343 .

1917 The internal strueture of the midbrain and thalamus of Necturus. Jour. Comp. Neur., vol. 28, p. 216.

Herrick, C. Judson, ANd Coghili, G. E. 1915 The development of reflex mechanisms in Amblystoma. Jour. Comp. Neur., vol. 25, p. 65.

Homén, E. A. 1890 Zur Kenntniss der Hemiatrophia facialis und des Ursprungs des Nervus Trigeminus. Neurol. Centbl., Heft 13, S. 385, 430.

Houser, G. L. 1901 The neurones and supporting elements of the brain of a selachian. Jour. Comp. Neur., vol. 11, p. 65.

Huber, G. CARL 1899 A note on sensory nerve-endings in the extrinsic eyemuscles of the rabbit. 'Atypical motor-endings' of Retzius. Anat. Anz., Bd. 15, S. 335.

1900 Sensory nerve terminations in the tendons of the extrinsic eye muscles of the cat. Jour. Comp. Neur., vol. 10, p. 152.

1927 New method of fixation and staining of the central nervous system for purpose of study of eytoarchitecture. Contr. to Medie. Sc. dedicated to Alfred S. Warthin. Ann Arbor. G. Wahr. 
Huber, G. Carl, and Crosby, Elizabeth C. 1926 On thalamic and tectal nuclei and fiber paths in the brain of the American alligator. Jour. Comp. Neur., vol. 40, p. 97.

Huguenis, G. 1879 Anatomie des centres nerveux. Paris. (Quoted from Duval, v. Gehuchten; Terterjanz.)

HULLES, EDUARD 1907 Zur vergleichenden Anatomie der cerebralen Trigeminuswurzel. Arb. a. d. Wien. Neur. Inst., Bd. 16, S. 469.

JACoBson, L. 1909 Über die kerne des menschlichen Hirnstammes. (Quoted from Kosaka.)

Johnston, J. B. 1900 The giant ganglion cells of Catostomus and Coregonus. Jour. Comp. Neur., vol. 10, p. 375 .

1905 The radix mesencephalica trigemini. The ganglion isthmi. Anat. Anz., Bd. 27, s. 364.

1909 The radix mesencephalica trigemini. Jour. Comp. Neur., vol. 19 , p. 593.

KAPPERS, C. U. ARIËNS 1910 The migrations of the motor cells of the trigeminus, abducens and facialis. Verh. der Kon. Acad. v. Wetenschappen, Deel 16, no. 4, p. 1. Amsterdam.

1920-1921 Die vergleichende Anatomie des Nervensystems der Wirbeltiere und des Mensehen. Bd. 1 und 2. Haarlem. Bohn.

Kingsbury, B. F. 1895 On the brain of Necturus maculatus. Jour. Comp. Neur., vol. 5, p. 138.

KuJATschisin, G. 1897 Experimentelle Untersuchungen über den Ursprung des N. trigeminus. Neurol. Centbl., S. 204.

Kohnstamm, O. 1900 Über die Coordinationskerne des Hirnstammes u. die absteigenden Spinalbahnen. Monatsch. f. Psych. u. Neur., Bd. 8, S. 261.

1910 Studien zur physiologisehen Anatomie des Hirnstammes, III. Jour. f. Psych. u. Neur., Bd. 17, S. 33.

Kohnstamm, O., UND Quensel, F. 1908 Studien zur physiologischen Anatomie des Hirnstammes, I. Jour. f. Psych. u. Neur., Bd. 13, s. 89.

1908 Über den Kern des hinteren Längsbündels, den roten Haubenkern u. den Nucleus intratrigeminalis. Neurol. Centbl., Bd. 27 , S. 242.

Kölliker, A. 1896 Handbueh der Gewebelehre. Aufl. 6, Bd. 2, S. 286. Leipzig.

Kosaka, K. 1912 Zur Frage der physiologisehen Natur der cerebralen Trigeminuswurzel. Folia Neurobiol., Bd. 6, S. 1.

Krause, W. 1905 Handbuch der Anatomie des Menschen, S. 539. Leipzig.

KuRE, SCHUzo 1899 Die normale und pathologische Structur der Zellen an der cerebralen Wurzel des Nervus trigeminus. Arb. a. d. Wien. Neur. Inst., Bd. 6, S. 159.

LarselL, 0.1923 The cerebellum of the frog. Jour. Comp. Neur., vol. 36, p. 104.

LEWANDOWSKY, M. 1904 Untersuchungen über die Leitungsbahnen des Truncus cerebri. Jenaische Denkschriften, Bd. 10.

VAN LONDEN, D. M. 1907 Untersuchungen betreffend den zentralen Verlauf des 'Nervus trigeminus' nach intracranieller Durchsehneidung seines Stammes. Petrus Camper. Nederl. Bijdr. tot de Anat., Deel 4, p. 285. 
Lugaro, E. 1894 Sull'origine di aleuni nervi encefalici. Arch. di ottalm., vol. 2. (Reviewed in Merkel-Bonnet, Erg. d. Anat. u. Entw., Bd, 4, S. 254.)

1895 Sur des cellules d'origine de la racine descendante du trijumeau. Arch. Ital. de biol., vol. 23, p. 78.

Mafratm, A. 1908 La portion motrice du trijumeau. Jour. f. Psych. u. Neur., Bd. 13 , S. 10 .

MAY, O., AND HoRsLex, V. 1910 The mesencephalic root of the fifth nerve. Brain, vol. 33, p. 175.

MAYSER, P. 1881 Vergleichend anatomische Studien über das Gehirn der Knochenfische. Ztseh. f. wiss. Zool., Bd, 36, S. 259.

McKibben, Pavl S. 1913 The eye-muscle nerves in Necturus. Jour. Comp. Neur., vol. 23, p. 153.

Mendei, E. 1888 Zur Lehre ven der Hemiatrophia facialis. Neurol. Centbl., Heft 14, S. 401.

Merkel, Fr. 1874 Die trophische Wurzel des Trigeminus. Unters. a. d. Anat. Inst. zu Rostock. (Reviewed in Jahresb. über d. Leist. in d. ges. Med., Bd. 1, S. 68.)

Meynerr, 'Th. 1867 Studien über die Bestandteile der Vierhügel. Ztsch. f. wiss. Zool., Bd. 17, S. 655 .

1872 The brain of mammals. In Stricker's Manual of Histology, American translation, p. 704, 708. W. Wood \& Co., New York.

MoFBIUS, PAUL 1895 Der umschriebene Gesichtsschwund. In Nothnagel's Hdb. d. spez. Path. u. Ther., Bd. 11.

NrcholLs, G. E. 1915 On the oceurrence of an intracranial ganglion upon the oculomotor nerve in Seyllium canieula. Proc. Roy. Soc. London, ser. B, vol. 88, p. 553 .

Nicholson, H. 1924 On the presence of ganglion cells in the third and sixth nerves in man. Jour. Comp. Neur., vol. 37, p. 31.

Nicolesco, I. 1926 Sur le noyau mésencéphalo-protubérantiel à cellules vésiculeuses. Rev. Neur., T. 1, no. 6, p. 975 .

Norrts, H. W. 1913 The cranial nerves of Siren lacertina. Jour. Morph., vol. 24, p. 245.

Obersteiner, H. 1888-1892-1901 Anleitung beim Studium des Baues der nervösen Zentralorgane.

OPPENHEIM, H. 1898-1913 Lehrbuch der Nervenkrankheiten.

OsBoRN, H. F. 1888 A contribution to the internal structure of the amphibian brain. Jour. Morph., vol. 2, p. 51.

Ponjatowsky, A. 1892 Über die Trigeminuswurzel im Gehirne des Menschen. Jahrb. f. Psych., Bd. 11, s. 98.

Probst, M. 1899 Über vom Vierhügel, von der Brücke und vom Kleinhirn absteigende Bahnen. D. Ztsch. f. Nervhlk., Bd. 15, S. 192.

Rabl-RÜcKhard, H. 1894 Einiges über das Gehirn der Riesenschlange. Ztsch. f. wiss. Zool., Bd. 58, S. 694 .

RAMón y CAJAL, P. 1896 Estructura del encéfalo del camaleón. Rev. trim. mierogr., T. 1, p. 46.

1898 Centros ópticos de las aves. Rev. trim. microgr., T. 3, p. 141.

1904 Origen del nervio masticador en las aves, reptiles y batracios.

Trab. Lab. Invest. biol. Madrid, T. 3, p. 153. 
RAMÓN Y CAJAL, S. 1896 Beitrag zum Studium der Medulla oblongata, des Kleinhirns und des Ursprungs der Gehirnnerven. Leipzig. Verl. Barth.

1909-1911 Histologie du système nerveux de l'homme et des vertébrés. T. 1 et 2 , Paris. Maloine.

RANSON, S. W. 1927 The anatomy of the nervous system from the standpoint of development and function. Saunders Co., Philadelphia and London.

RoHoN, J. V. 1878 Das Centralorgan des Nervensystems der Selachier. Denksehr. d. Kais. Ac. d. Wiss. Math. nat. Cl. Wien, Bd. 38, Abt. 2, S. 43.

RöTHIG, PAUL 1927 Beitrag zum Studium des Zentralnervensystems der Wirbeltiere. Ztsch. f. mikr. anat. Forsch., Bd. 2, S. 410, 454.

SARgent, Porter E. 1901 The development and function of Reissner's fibre and its cellular connections. A preliminary paper. Proceed. Amer. Ac. of Arts and Se., vol. 36, p. 445 .

1904 The optic reflex apparatus of vertebrates for short-cireuit transmission of motor reflexes through Reissner's fiber. Bull. Mus. Comp. Zoöl. Harvard, vol. 45, p. 127.

Schwalbe, G. 1881 Lehrbuch der Neurologie. Erlangen, S. 678.

Sherrington, C. S. 1894 On the anatomical constitution of nerves of skeletal muscles, with remarks on recurrent fibers in the ventral spinal roots. Jour. Physiol., vol. 17, p. 211.

1897 Further note on the sensory nerves of muscles. Proc. Roy. Soc. London, vol. 61, p. 247.

1898 Further note on the sensory nerves of the eye-museles. Proc. Roy. Soe. London, vol. 64, p. 120.

StTeda, Ludw. 1870 Studien über das centrale Nervensystem der Wirbeltiere. Ztsch. f. wiss. Zool., Bd. 20, S. 349, 367, 375.

Strlling, B. .1846 Disqusitiones de structura et functionibus cerebri. Jenae. (Quoted from Duval, '78.)

TAKEDA, G. 1925 Beitrag zur histologisehen Kenntniss des Nervus Trigeminus. Folia Anatomica Japonica, vol. 3.

Thelo, F. 1909 Contribución al conocimiento del encéfalo de los teleósteos. Trab. Lab. Invest. biol. Madrid, T. 7, p. 1.

Terni, T. 1912 Contributo all conscenza del nucleo mesencephalico del nervo trigemino. Monit. Zool. ital., Anno 23, no. 2. (Reviewed in Folia Neurobiol., Bd. 7, 1913, S. 195.)

Termerjanz, M. 1899 Die obere Trigeminuswurzel. Arch. f. mikr. Anat. u. Entw., Bd. 53, S. 632.

Thelander, H. E. 1924 The course and distribution of the radix meseneephaliea trigemini in the eat. Jour. Comp. Neur,, vol. 37, p. 207.

Tooth, H. H. 1893 Destructive lesion of the fifth nerve trunk. St. Bartolom. Hosp. Rep., vol. 29, p. 215.

Tozer, F. M. 1912 On the presence of ganglion cells in the roots of III, IV and VI cranial nerves. Jour. Physiol., vol. 45, p. XV.

Tozer, F. M., AND SHERRINGToN, C. S. 1910 Receptors and afferents of the third, fourth and sixth cranial nerves. Proc. Roy. Soc. London, ser. B, vol. 82 , p. 450 . 
TURner, C. H. 1891 Morphology of the avian brain. Jour. Comp. Neur., vol. 1 , p. $39,107,265$.

VALETON, M. T. 1908 Beitrag zur vergleichenden Anatomie des hinteren Vierhügels des Mensehen und einiger Säugetiere. Arb. a. đ. Wien. Neur. Inst., Bd. 14, s. 29.

VAN VALKENBURG, C. T. 1911 Zur vergleichenden Anatomie des mesencephalen Trigeminusanteils. Folia Neurobiol., Bd. 5, S. 360.

WarLenberg, A. 1904 Neue Untersuchungen über den Hirnstamm der Taube. III. Die cerebrale Trigeminuswurzel. Anat. Anz., Bd. 25, S. 526.

1904 Nachtrag zu meinem Artikel über die cerebrale Trigeminuswurzel der Vögel. Anat. Anz., Ba. 25, S. 621.

WARRINGTON, W. B., AND GRIFFith, F. 1904 On the cells of the spinal ganglia and on the relationship of their histological structure to the axonal distribution. Brain, vol. 27, p. 297.

Wernicke, C. 1881 Lehrbuch der Gehirnkrankheiten. Bd. 1, Kassel.

Wiedersheim, R. 1909 Vergleichende Anatomie der Wirbeltiere. Aufl. 7. Jena.

WILLEMs, ED. 1911 Localisation motrice et kinéstesique. Les noyaux masticateurs et mésencéphaliques du trijumeau chez le lapin. Nevraxe, T. 12 , p. 1.

Winkler, Corn. 1918-1921 Anatomie du système nerveux. Haarlem. Bohn. (Quoted from Freeman.)

Winkler, Corn., and Potter, A. 1914 An anatomical guide to experimental researches on the eat's brain. Amsterdam. Versluys. 